\title{
Middle-Late Permian (Murgabian-Djulfian) foraminifers of the northern Maku area (western Azerbaijan, Iran)
}

\author{
Mobin Ebrahim Nejad, Daniel Vachard, \\ Ali Asghar Siabeghodsy, and Syrus Abbasi
}

\begin{abstract}
The Maku section is located in western Azerbaijan (NW Iran), near Adaghan and Ali Abad villages, in the vicinity of Maku town, along the main road from Tabriz to Bazargan. The Permian Ruteh Formation of the Maku area is subdivided here into four biozones: (1) Neoschwagerina simplex Zone (samples P1-P21; early Murgabian); (2) an unzoned interval which corresponds probably to the rest of the Murgabian (samples P22-P29); (3) Sumatrina annae, Dunbarula aff. pusilla and Chusenella spp. Zone (samples P30-P41, P46?; Midian); (4) Paraglobivalvulina mira, Paradagmarita? sp., Rectostipulina quadrata, Ichthyofrondina spp., Pseudotristix sp. and Colaniella aff. minuta Zone (samples P47 to top unconformity; Djulfian = Wuchiapingian). The studied foraminiferal assemblages show relatively rare tuberitinids, palaeotextulariids, earlandiids, endothyrids and neoendothyrins. Conversely, the globivalvulinids are diversified, with the globivalvulinins Globivalvulina, Labioglobivalvulina, Septoglobivalvulina, Retroseptellina, Charliella? and Paraglobivavulina; rare dagmaritins represented by the same two species along all the series; and primitive paradagmaritins characteristic of the Djulfian. Fusulinida are dominated by staffelloids (Sphaerulina, Nankinella), whereas schubertelloids (Schubertella, Grovesella, Grovesella? and Dunbarula), schwagerinoids (Chusenella) and neoschwagerinoids (Neoschwagerina and Sumatrina) remain rare and scattered. Miliolates and Nodosariates are relatively diversified. Excellent specimens of Pseudovermiporella definitively evidenced the assignment of this taxon to the Miliolata. Other representatives of this class are Hemigordius, Okimuraites, Hemigordiellina, Glomomidiella, Agathammina, Neodiscus and Crassiglomella. The Middle Permian Nodosariata are represented by Syzrania, Rectostipulina, Nodosinelloides, Protonodosaria, Langella, Pseudolangella?, Lingulina, Pseudotristix, Geinitzina, Pachyphloia and rare Robuloides; whereas Frondina and Ichythyofrondina are numerous in the Djulfian. The new taxa are Grovesella? ciryi n. sp. and Hemigordiellina? pulchrissima $\mathrm{n}$. sp.
\end{abstract}

http://zoobank.org/D07BF4E9-DAB9-4B9F-BDAD-3F24AF01648A

PE Article Number: 18.1.19A

Copyright: Palaeontological Association April 2015

Submission: 23 December 2013. Acceptance: 7 February 2015

Ebrahim Nejad, Mobin, Vachard, Daniel, Siabeghodsy, Ali Asghar, and Abbasi, Syrus. 2015. Middle-Late Permian (Murgabian-Djulfian) foraminifers of the northern Maku area (western Azerbaijan, Iran). Palaeontologia Electronica 18.1.19A: 1-63. palaeo-electronica.org/content/2015/1079-middle-to-late-permian-foraminifera 
Mobin Ebrahim Nejad. Young Researchers and Elite Club, Tabriz Branch, Islamic Azad University, Tabriz, Iran ebrahimnezhad_2008@yahoo.com

Daniel Vachard. Université Lille 1, UMR 8217 Géosystèmes, SN5, 59655 Villeneuve d'Ascq Cédex, France Daniel.Vachard@univ-lille1.fr Ali Asghar Siabeghodsy. Academic Member at Department of Geology, Faculty of Science, University of Urmia, Iran a.siabeghodsy@urmia.ac.ir Syrus Abbasi. Islamic Azad University of Science and Research of Tehran, Geological survey of Iran,Tabriz branch syrus_abbasi@yahoo.com

Keywords: Middle-Late Permian; NW Iran; foraminifers; new genus; new species

\section{INTRODUCTION}

The studied area forms a part of the AlborzAzerbaijan unit (Figure 1), one of the 17 structural and sedimentological units defined by Nabavi (1976), in Iran. The Permian rocks are widespread in this unit, as well as in central Iran, Sanandaj-Sirjan Zone and Zagros (Figure 1).

Permian rocks of Azerbaijan are lithostratigraphically equivalent of the classical formations of the Alborz Mountains: Dorud, Ruteh and Nesen. The Ruteh Formation, defined in Alborz by Assereto (1963), displays a sequence relatively homoge- neous of grey to dark limestone with intercalated marl. Lasemi (2001) characterized the sedimentary palaeoenvironments of the Ruteh Formation as equivalents of modern carbonate environments of the southern shelves of Persian Gulf with open sea, barrier, lagoon and tidal flat, respectively. The erosional lower boundary of the Ruteh Formation rests everywhere unconformably on the older lithological units (Aghanabati, 2006). The erosional surface with the Dorud Formation occasionally is underlined by a lateritic layer, which Stampfli (1978) interpreted as the unique record of the regional Artinskian-Kungurian gap. The upper sur-

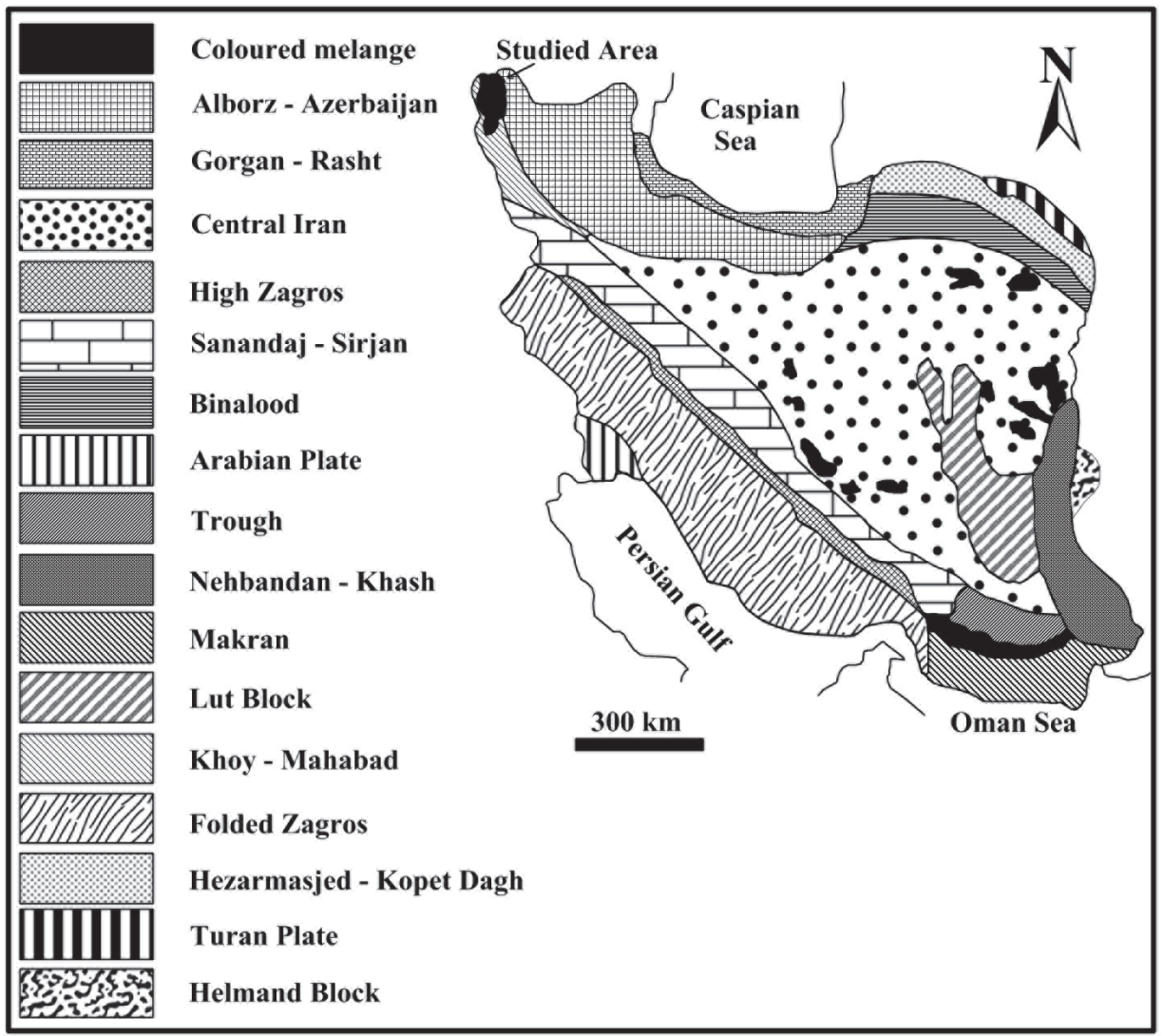

FIGURE 1. Structural and sedimentological units of Iran (Nabavi, 1976). 


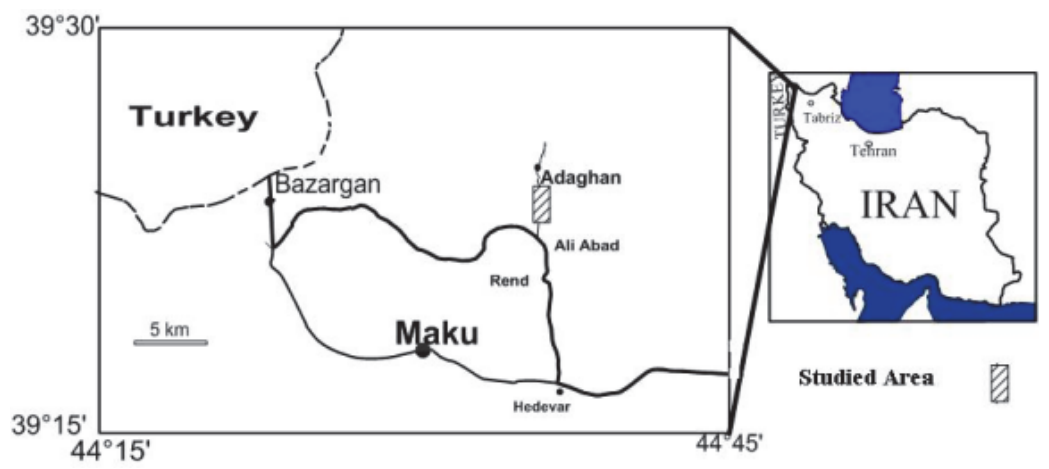

FIGURE 2. Location of studied area.

face of the Ruteh Formation is regionally marked by a karstic surface, locally filled by volcanic lavas and/or bauxite-laterite deposits (Shabani and Baghbani, 2008), while the Ruteh Formation is continuously overlain by the Elika Formation (Triassic) and/or Shemshak Formation (TriassicJurassic) in most areas of southern Alborz areas, or has a discontinuous contact with the latest Permian (Dorashamian $=$ Changhsingian) Nesen limestone, in northern Alborz.

Late Permian rocks largely crop out in Azerbaijan especially in the classical area of Julfa (= Djulfa, Djoulfa or Dzhulfa, according to the translitterations), where the Djulfian stage has been defined, and where the Permian-Triassic boundary is well exposed. The first comprehensive study of the Julfa section was conducted by Stepanov et al. (1969) who subdivided the Permian and the Triassic strata into seven units: " $A$ " to " $G$ ". Another pioneer description of the Julfa area sections (especially of the Ali Bashi Mountains) was provided by Teichert et al. (1973). Biostratigraphic data (e.g., Kozur, 2004, 2005, 2007; Shen and Mei, 2010) and chemostratigraphic interpretations (Holser and Magaritz, 1987; Baud et al., 1989; Korte et al., 2004; Korte and Kozur, 2005; Kakuwa and Matsumoto, 2006; Richoz, 2006; Horacek et al., 2007; Richoz et al., 2010) were published for the Permian-Triassic sequences in the Ali Bashi sections. They provided a significant increase of the geological and palaeontological data and probably have allowed a nearly definitive geological schema of the region to be conceived. Nevertheless, in other areas of Azerbaijan, although the Ruteh Formation is extensively exposed (Aghanabati, 2006), its accurate biostratigraphy remained poorly known (e.g., Shabanian and Bagheri, 2008, with references therein), especially the Maku area.

Contrary to the Armenian and Turkish outcrops (Akopian, 1974; Altiner et al., 1980; Kotlyar et al., 1984, 1989; Pronina, 1988a; Altiner, 1984;
Köyluoglu and Altiner, 1989) located in the other side of the Iranian border, the iconography of the foraminifers and algae remained very poor in NW Iran, so another goal was to publish an atlas more or less similar to the Bozorgnia's atlas for the Alborz (Bozorgnia, 1973). This monography is therefore the first one dedicated to these very rich levels of Maku and tries to be the cornerstone for future micropalaeontogical research in this area. Hence, the aims of this work were: (1) the detailed biostratigraphical characterization of the Ruteh Formation in the Maku locality, (2) the description of its foraminifers, (3) the possible identification of lateral equivalents with the classical Julfa area and (4) the discussion of various palaeobiogeographical hypotheses concerning either the northern (i.e., Perigondwanan) border of the Neo-Tethys or the southern border of the Cimmerian continent.

\section{GEOLOGICAL SETTING}

The Maku section is located near Adaghan and Ali Abad villages, in the vicinity of Maku town, NW Iran (latitude $39^{\circ} 32^{\prime} 20^{\prime \prime}-39^{\circ} 22^{\prime} 05^{\prime \prime} \mathrm{N}$ and longitude $44^{\circ} 33^{\prime} 40^{\prime \prime}-44^{\circ} 39^{\prime} 50^{\prime \prime} \mathrm{E}$ ), along the main road from Tabriz to Bazargan (Figure 2).

The oldest Palaeozoic lithological units in the studied area are Silurian volcanic rocks (Figure 3 ). They are successively overlain by (a) the sediments of the Ilanqareh Formation (Late Devonian to earliest Mississippian) consisting of shale, quartzite, limestone, and phosphate layers (more or less $1300 \mathrm{~m}$ thick; according to Alavi Naini and Bolourchi, 1973), (b) the Middle Mississippian Limestone of the Mobarak Formation, and (c) the Permian Ruteh Limestone, especially studied here. North of Maku, this latter directly and disconformably rests on the llanqareh Formation (Figure 4). The Early Miocene Qom Formation (conglomerate, limestone, and marl), more or less $700 \mathrm{~m}$ thick, unconformably overlies the older formations (Alavi 


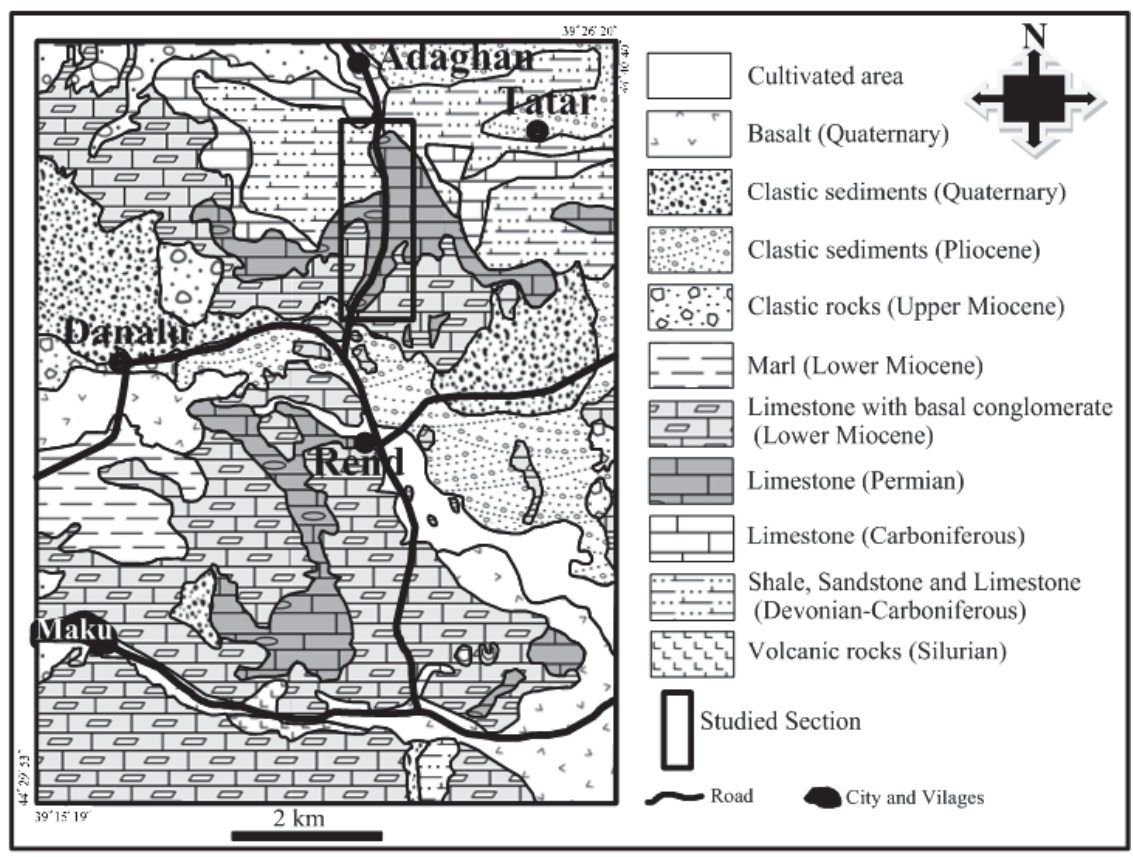

FIGURE 3. Geological map of studied area.

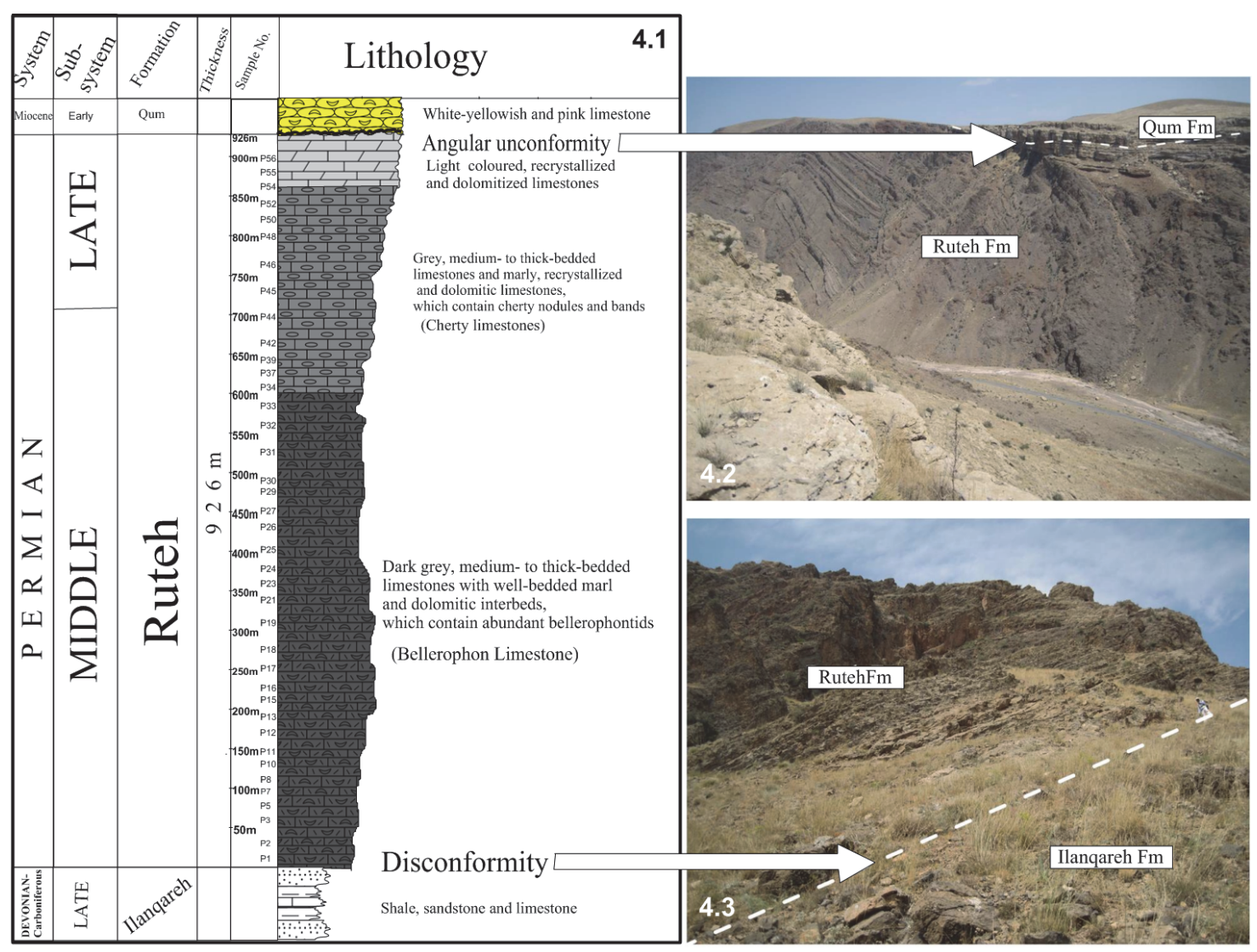

FIGURE 4. 4.1: The studied series with the thicknesses and sample locations. 4.2: Upper contact with the Cenozoic Qum Formation. 4.3: Lower conctat with the Devonian-Carboniferous Ilanqareh Formation. 


\begin{tabular}{|c|c|c|c|c|}
\hline SYSTEM & SERIES & INTERNATIONALSTAGES & & ETHYANSTAGES \\
\hline \multirow{10}{*}{ PERMIAN } & \multirow{2}{*}{ LATE } & CHANGHSINGIAN & \multicolumn{2}{|r|}{ DORASHAMIAN } \\
\hline & & WUCHIAPINGIAN & \multicolumn{2}{|r|}{ DJULFIAN } \\
\hline & \multirow{4}{*}{ MIDDLE } & CAPITANIAN & \multicolumn{2}{|r|}{ MIDIAN } \\
\hline & & WORDIAN & Vm & \multirow{2}{*}{ MURGABIAN } \\
\hline & & \multirow{2}{*}{ ROADIAN } & c & \\
\hline & & & \multicolumn{2}{|r|}{ KUBERGANDIAN } \\
\hline & \multirow{4}{*}{ EARLY } & KUNGURIAN & & BOLORIAN \\
\hline & & ARTINSKIAN & & YAKHTASHIAN \\
\hline & & SAKMARIAN & & HERMAGORIAN \\
\hline & & ASSELIAN & & ASSELIAN \\
\hline
\end{tabular}

FIGURE 5. Proposed correlation between the international and Tethyan scales of the Permian system (according to Leven, 1967, 1975, 1981, 1992, 1997; Henderson et al., 2012; Davydov et al., 2013; and D. Vachard (unpublished data)). Abbreviations: $\mathrm{e}=$ early $\mathrm{l} / \mathrm{m}=$ late/middle.

Naini and Bolourchi, 1973). Quaternary basaltic flows constitute the youngest rocks in the area (Figure 3).

The Ruteh Formation is one of the most fossiliferous units in Alborz-Azerbaijan. The corals, brachiopods, algae and foraminifers of the Alborz Mountains have been accurately studied in the $20^{\text {th }}$ century, and generally assigned to the Middle Permian (Murgabian-Midian). Lithostratigraphically, the Ruteh Formation in Azerbaidjan was correlated with the Jamal Formation in Central Iran and/or Gnishik layers in Julfa Mountains (Iran) and in Armenia. Furthermore, Bozorgnia (1973) suggested that the uppermost 25 metres of the Ruteh Formation, in some sections of Alborz, might be assigned to the Djulfian. Our study confirms the presence of the three stages, Murgabian, Midian and Djulfian within the formation in Maku.

There was only a lithostratigraphic study of the Ruteh Formation in Maku area (Alavi Naini and Bolourchi, 1973), where this formation was subdivided into two informal members ( $A$ and $B$ ). Our new data are summarized in the Figure 4.

The Ruteh Formation of Maku (Figure 4.1), $926 \mathrm{~m}$ thick, disconformably rests upon the Devonian-Carboniferous Ilanqareh Formation and is overlain by the Early Miocene Qum Formation with an angular unconformity (Figure 4.2-3). It is subdivided into three units: (1) the Bellerophon limestone, $604 \mathrm{~m}$ thick, composed of dark grey, medium- to thick-bedded limestone with marl and dolomitic limestone interbeds, with abundant bellerophontids, corals, crinoids, brachiopods, ostracods and algae; (2) the cherty limestone $(261 \mathrm{~m}$ thick), composed of lighter coloured, grey, mediumto thick-bedded limestone and marly, crystallized, dolomitic limestone with nodules and bands of chert; (3) the last unit (61 m thick) is a light coloured, dolomitized limestone with brachiopods and ostracods.

\section{BIOSTRATIGRAPHY}

The stages and biozones of the Tethyan Realm were defined by Leven (1967, 1975, 1981, 1992, 1997). A correlation with the international scales of Henderson et al. (2012) is suggested below (Figure 5 ).

The foraminiferal composition and distribution of the Ruteh Formation of Maku is indicated in Figure 6 . The discovered foraminifers permit to subdivide this formation into four biozones; namely, (1) Neoschwagerina simplex Zone (samples P1-P21; early Murgabian); (2) an unzoned interval which corresponds to the rest of the Murgabian Stage (samples P22-P29); (3) Sumatrina annae, Dunbarula aff. pusilla and Chusenella spp. Zone (samples P30-P41 P46?; Midian); (4) Paradagmarita? sp., Paraglobivalvulina mira, Ichthyofrondina spp., Pseudotristix sp., Colaniella aff. minuta, and Rectostipulina quadrata Zone (samples P47 to the top 


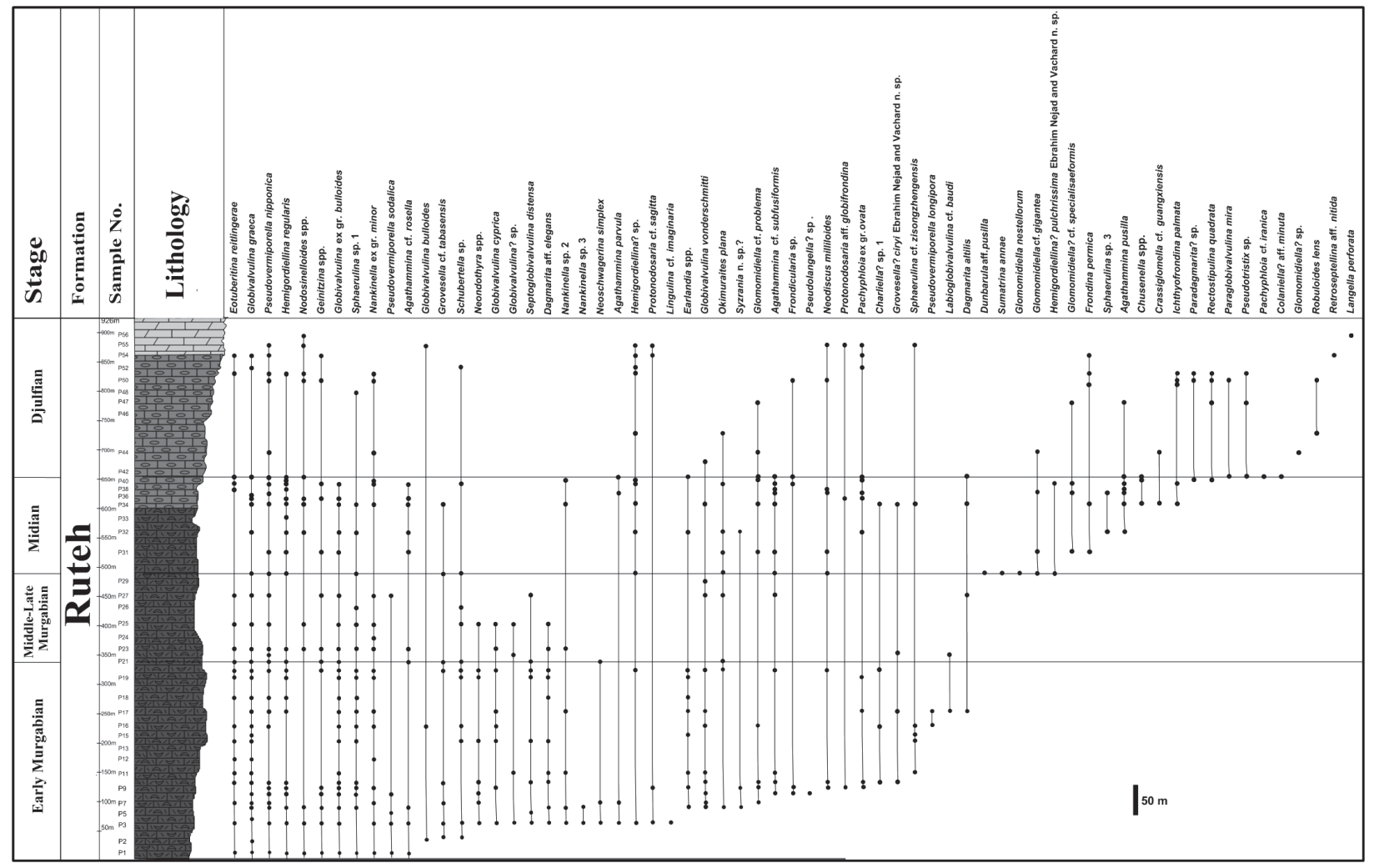

FIGURE 6. Foraminiferal distribution of the Ruteh Formation in Maku section (NW Iran).

of the series and the unconformity; Djulfian = Wuchiapingian), with the following remarks:

1. The FO (first occurrence) of Neoschwagerina simplex in P3 characterizes the base of the series P1-P21 as being early Murgabian in age.

2. The interval P22-P29 is devoid of characteristic fossils, and is either still early Murgabian or yet middle and/or late Murgabian in age. Consequently, the local middle and/or late Murgabian is very reduced in thickness or eventually absent.

3. The FO of Sumatrina annae and primitive Dunbarula aff. pusilla in P30 indicates the base of the Midian Stage. The LO (last occurrence) of Chusenella spp. in P41 is the upper limit of the Midian, based on the general disappearance of all the giant fusulinids like Chusenella at this limit. Consequently, the entire Midian might correspond to the interval containing the samples P30 to P46.

4. The concomitant FOs of Paradagmarita? sp., Paraglobivalvulina mira, Ichthyofrondina spp., Pseudotristix sp., Colaniella aff. minuta, and Rectostipulina quadrata in P47, indicate the
Djulfian (= Wuchiapingian = early Late Permian; see Figure 5), because all these small taxa correspond to the classical Lilliput effect at the base of the Late Permian. No younger biomarkers, e.g., Nanlingella, Paraglobivalvulinoides and evolved Colaniella (known for example in the Alborz (e.g., Bozorgnia, 1973)) were found above; therefore, this interval (samples P47-P56) is dated as Djulfian (and probably early Djulfian).

\section{SYSTEMATIC PALAEONTOLOGY}

The following foraminiferal classification is based on those of Gaillot and Vachard (2007), Vachard et al. (2010) and Hance et al. (2011); taking into consideration those of Loeblich and Tappan (1987, 1992), Vdovenko et al. (1993), RauzerChernousova et al. (1996) and Mikhalevich (1998, 2004) (Figure 7-19). Abbreviations: $L=$ length, $H=$ height, $\mathrm{D}=$ outer diameter, $\mathrm{d}=$ inner diameter, $\mathrm{w}=$ width, $w / D=$ form ratio, $p=$ proloculus diameter, $n$ $=$ number of whorls, $\mathrm{h}=$ height of last whorl or last chamber and $\mathrm{s}=$ wall thickness.

Phylum RHIZARIA Cavalier-Smith, 2002 Subphylum FORAMINIFERA d'Orbigny, 1826 nom. 


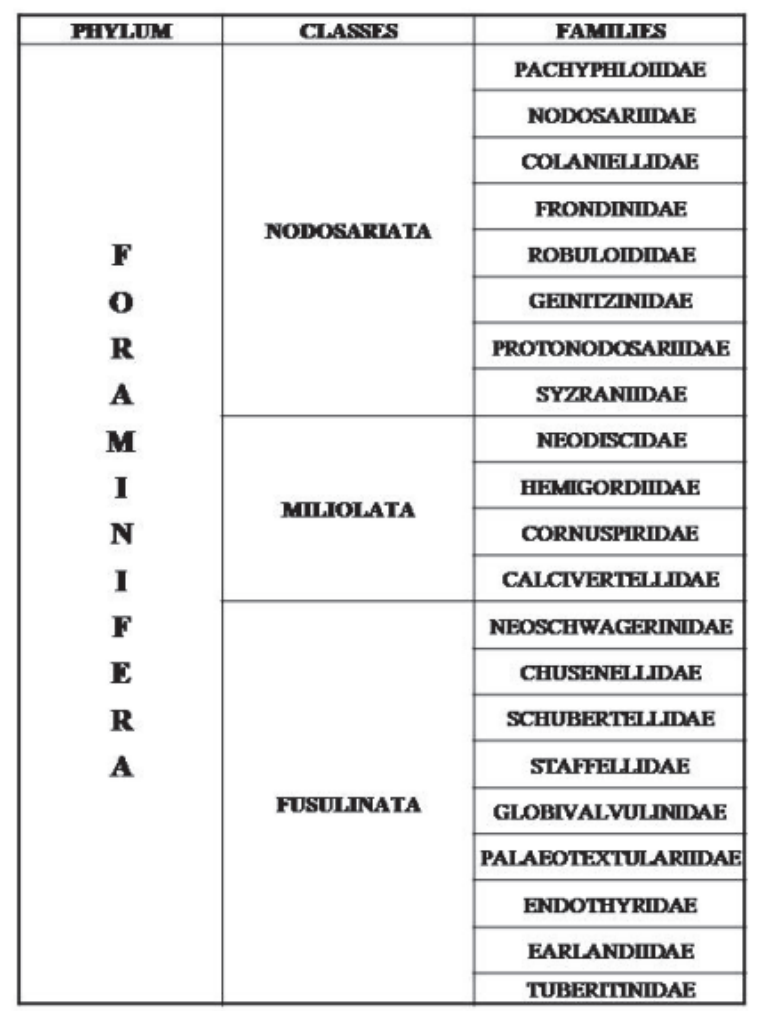

FIGURE 7. Classes and families of foraminifers described in this study (classification after Vachard et al., 2010 and Hance et al., 2011).

translat. Cavalier-Smith, 2003

Class FUSULINATA Möller, 1878 (non Fursenko, 1958) nom. translat. Gaillot and Vachard, 2007 nom. correct. Vachard, Krainer and Lucas, 2013

Subclass AFUSULINANA Vachard, Pille and Gaillot, 2010

Order ?PARATHURAMMINIDA Bykova in Bykova and Polenova, 1955 nom. translat. Mikhalevich, 1980

Family TUBERITINIDAE Miklukho-Maklay, 1958

Discussion. Despite their resemblances with some unilocular foraminifers with microgranular walls (Parathuramminida), the tuberitinids remain incertae sedis microfossils, because of some very peculiar characters, like the microstructures of their wall, their frequent mutual attachment, and the existence of a double life, free and attached (Conil and Lys in Conil et al., 1977). This latter character might indicate a relationship with the euglenophyta but this group is not calcified. No true foraminifers have a biological tolerance comparable to that of the tuberitinids. As indicated by Vachard (1994), some microstructural similarities might exist with the Calcitarcha Calcisphaeridae (e.g., Tubesphaera Vachard, 1994). Appeared in the Silurian, the group is present up to the Permian-Triassic Boundary (Vachard, 1994); it does not cross through this limit. The presence of tuberitinids in the Early Triassic, suggested by Song et al. (2011) result probably of the confusion of oblique sections through two chambers of foraminifers with the morphogenus Diplosphaerina Derville, 1952 (the free stage of Eotuberitina). This remark may appear anecdotal but it constitutes for us an evidence of the severeness of the PTB event; because the tuberitinids which resisted to all the previous Palaeozoic crises, finally disappeared at the PTB. Occurrence. Silurian to latest Permian (Vdovenko et al., 1993); cosmopolite.

Genus EOTUBERITINA Miklukho-Maklay, 1958

Type species. Eotuberitina reitlingerae MiklukhoMaklay, 1958, p. 134 by original designation (nomen novum pro Tuberitina maljavkini sensu Reitlinger, 1950 non Mikhailov, 1939; see Loeblich and Tappan, 1987).

Eotuberitina reitlingerae Miklukho-Maklay, 1958 Figure 8.1-8.4

1958 Eotuberitina reitlingerae MiklukhoMaklay, p. 134 (see Reitlinger, 1950, p. 88, pl. 19, fig. 2).

Remarks. Very small Tuberitinidae with a flat to convex basal attachment disc and a thin microgranular wall. Groups of 2-3 specimens (rarely 4-5) can encrust themselves (see e.g., Zheng Hong, 1989, pl. 1, figs. 8-14, 26-27; Mamet, 1996, pl. 3, fig. 20; Nestell and Nestell, 2006, pl. 1, figs. 1-4, 7$8)$. The dimensions of our Permian material $(D=$ $0.050-0.100 \mathrm{~mm} ; \mathrm{H}=0.040-0.080 \mathrm{~mm}$ ) are consistent with those of the type material, despite the Viséan age of this latter.

Occurrence. The presence of Eotuberitina reitlingerae up to Changhsingian times has been indicated by Lin et al., 1990; Vachard et al., 1993a; Berczi-Makk et al., 1995; Pronina-Nestell and Nestell, 2001; Zhang and Hong, 2004; Gaillot and Vachard, 2007; etc. Our specimens were observed in many samples of Maku (P1, P3, P7, P10, P11, $\mathrm{P} 12$, P14, P16, P17, P18, P19 (relatively common), P20, P21, P23, P25, P27, P38, P39, P41, P51 and P54).

Order EARLANDIIDA Cummings, 1955 nom. translat. Loeblich and Tappan, 1982

Family EARLANDIIDAE Cummings, 1955 emend.Vachard, 1994

Genus EARLANDIA Plummer, 1930

Type species. Earlandia perparva Plummer, 1930. 


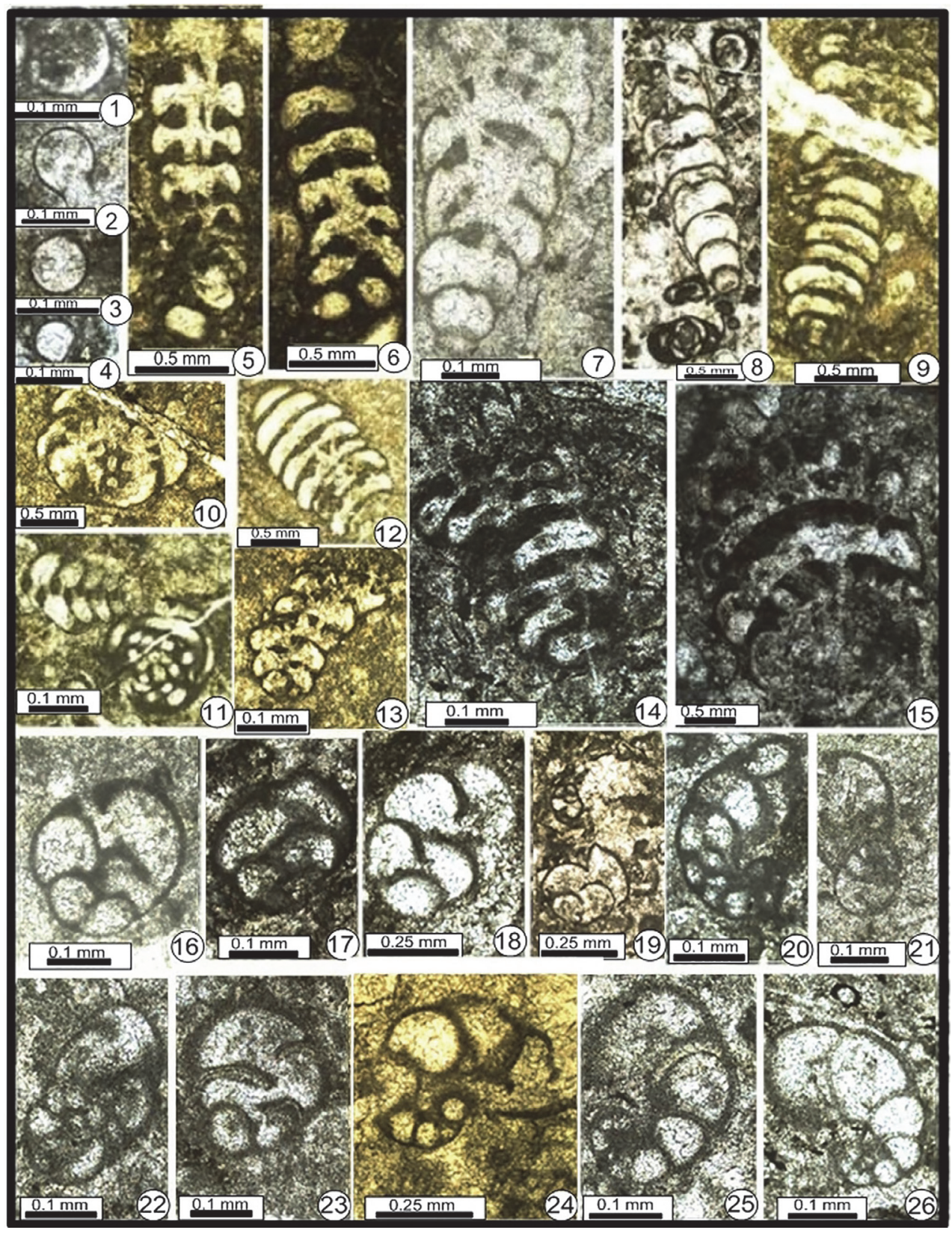

FIGURE 8. 1-4. Eotuberitina reitlingerae Miklukho-Maklay, 1958. 1. P18-5. Murgabian. 2. P17-34. Murgabian. 3. P10-33. Murgabian. 4. P23-17. Murgabian. 5-6, 11. Deckerella sp. 5. P41-17. Latest Midian. 6. Longitudinal section. P41-11. Latest Midian. 11. Initial stage similar to Palaeotextularia, with Hemigordiellina regularis (Lipina, 1949). P4156. Latest Midian. 7-8. Cribrogenerina sp. 1. 7. Subaxial section with Okimuraites plana (Okimura and Ishii, 1981) (B; bottom left and top right). P21-50. Murgabian. 8. Oblique section with Neodiscus milliloides Miklukho-Maklay, 1953 (bottom, left). P20-30. Murgabian. 9, 12. Cribrogenerina sp. 2. 9. Subaxial section. P52-1. Djulfian. 12. Subaxial section. P50-33. Djulfian. 10, 13. Climacammina sp. 1. 10. Subtransverse section. P52-13. Djulfian. 13. Longitudinal section. P50-35. Djulfian. 14-15. Climacammina sp. 2. 14. Subaxial section. P34-36. Midian. 15. Oblique section. P34-17. Midian. 16. Labioglobivalvulina cf. baudi Gaillot and Vachard, 2007. Subaxial section. P3-40. Murgabian. 17, 19. Globivalvulina bulloides (Brady, 1876). 17. Axial section. P1-3. Murgabian. 19. Axial section (top left) with G. graeca (bottom). P2-2. Murgabian. 18, 20. Globivalvulina ex gr. bulloides (Brady, 1876). 18. Axial section. P120. Murgabian. 20. Transverse section. P1-27. Murgabian. 21-22. Globivalvulina cyprica Reichel, 1946. 21. Axial section. P17-31. Murgabian. 22. Transverse section. P17-16. Murgabian. 19, 23-26. Globivalvulina graeca Reichel, 1946. 19. Axial section (bottom) with G. bulloides (top left). P2-2. Murgabian. 23. Axial section. P17-11. Murgabian. 24. Transverse section. P22. Murgabian. 25. Transverse section. P17-29. Murgabian. 26. Transverse section. P638. Murgabian. 


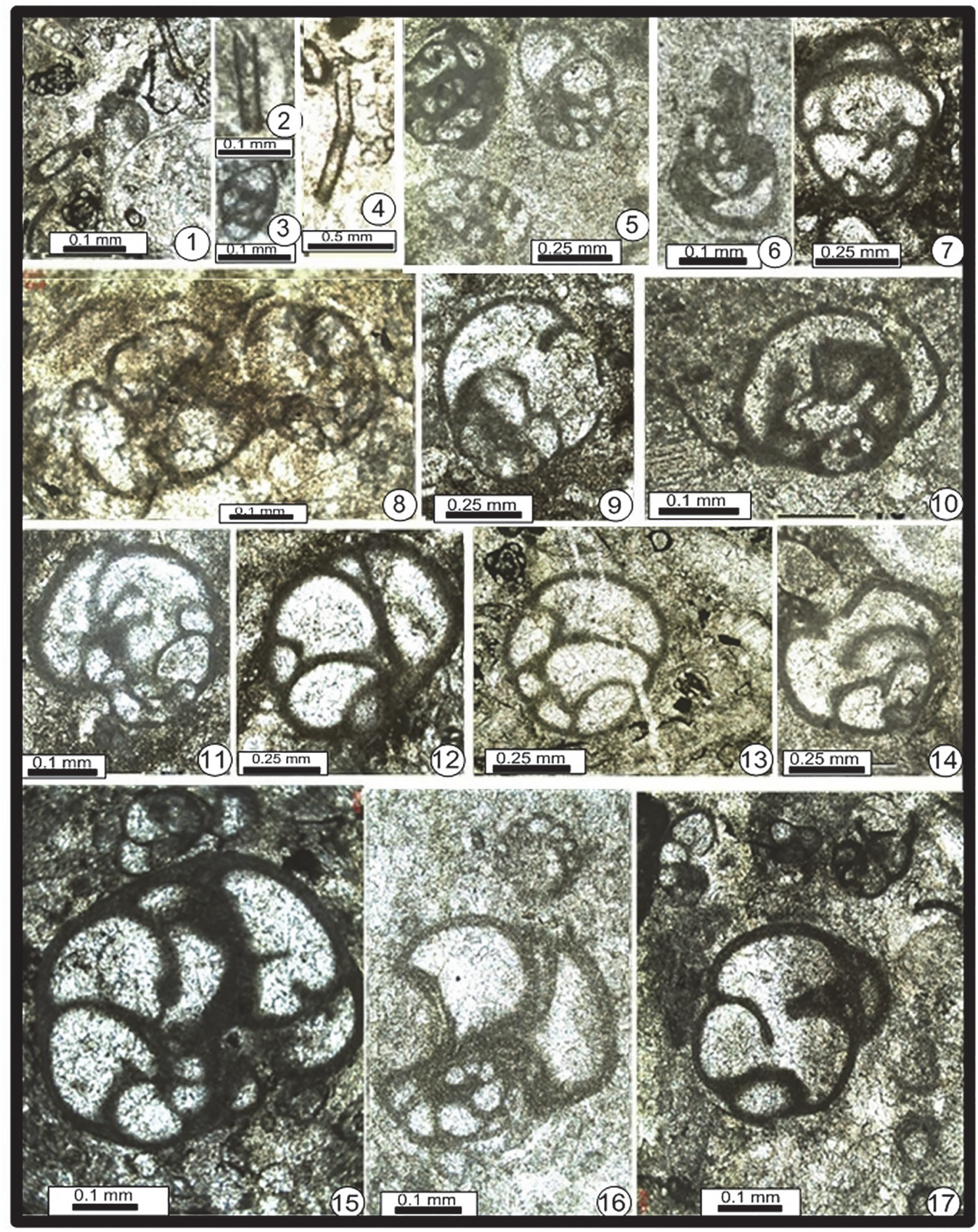

FIGURE 9. 1-2. Earlandia ex gr. elegans (Rauzer-Chernousova and Reitlinger in Rauzer-Chernousova and Fursenko, 1937). 1. Longitudinal section (top left) with Geinitzina sp. (top left) and Hemigordiellina regularis (Lipina, 1949) (bottom and top, left). P17-11. Murgabian. 2. Longitudinal section. P17-13. Murgabian. 1, 4. Earlandia ex gr. minor (Rauzer-Chernousova, 1948). 1. Oblique section (bottom left). P17-11. Murgabian. 4. Longitudinal section. P31-30. Murgabian. 3. Endothyra? sp. Axial section. P8-5. Murgabian. 5. Endothyra cf. miassica Malakhova, 1965. Transverse section (top, left) with Globivalvulina graeca Reichel, 1946 (top right) and Nankinella ex gr. minor Sheng, 1955 (bottom left). P10-64. Murgabian. 6. Neoendothyra sp.. Axial section. P25-1. Murgabian. 7, 11-14. Globivalvulina graeca Reichel, 1946. 7. Subaxial section. P1-18. Murgabian. 11. Subaxial section. P1-29. Murgabian. 12. Subtransverse section. P1-14. Murgabian. 13. Subaxial section with 3 specimens of Hemigordiellina regularis (Lipina, 1949). P6-6. Murgabian. 14. Axial section. P16-41. Murgabian. 8. Septoglobivalvulina distensa (Wang in Zhao et al., 1981). Two sections. P5-2. Murgabian. 9. Globivalvulina ex gr. bulloides (Brady, 1876). Axial section. P1-15. Murgabian. 10. Paraglobivalvulina cf. mira Reitlinger, 1965. Axial section. P25-24. Murgabian. 15-17. Globivalvulina vonderschmitti Reichel, 1946. 15. Transverse section with Globivalvulina bulloides. P34-35. Midian. 16. Transverse section with a Nankinella? sp. (top right). P11-8. Murgabian. 17. Subaxial section with Globivalvulina ex gr. bulloides (top left); transitional taxon to Paradagmarita (top, centre) and Labioglobivalvulina cf. baudi (top right). P22-9. Murgabian. 
Earlandia spp.

Figure 9.1-9.2, 9.4

Remarks. Two groups of species seem to be relatively common in our samples P3, P6, P9, P10, P11, P15, P17, P18, P19, P20, P21, P32 and P40. The small taxon is Earlandia ex gr. elegans (Rauzer-Chernousova and Reitlinger in Rauzer-Chernousova and Fursenko, 1937) (Figure 9.1-9.2; $\mathrm{D}=$ $0.050-0.075 \mathrm{~mm}$ ); the second one is the mediumsized Earlandia ex gr. minor (Rauzer-Chernousova, 1948) (Figure 9.1, 9.4; $\mathrm{D}=0.120-0.200$ $\mathrm{mm}$ ). Gaillot and Vachard (2007) have given good arguments to assign the small tubular microgranular Permian tests to Earlandia. Nevertheless, some authors (e.g., Hughes, 2012) prefer to use Aeolisaccus Elliott, 1958. It was tried to justify two genera using the difference of wall microstructures (Vachard, 1980), but it seems evident now that all these tubes belong to Earlandia.

Occurrence. Late Silurian-Early Cretaceous, cosmopolite.

Subclass FUSULININA Möller, 1878 nom. translat. Vachard et al., 2010

Superfamily ENDOTHYROIDEA Brady, 1884 nom. translat. Glaessner, 1945

Family ENDOTHYRIDAE Brady, 1884 nom. translat. Rhumbler, 1895

Genus ENDOTHYRA Phillips, 1846 sensu Brady, 1876 emend. China, 1965

Type species. Endothyra bowmani Phillips, 1846 sensu Brady, 1876 emend. China, 1965.

\section{Endothyra spp.}

Figure 9.3?, 9.5

Remarks. Very rare specimens (in P8 and P10), either similar to Endothyra miassica Malakhova, 1965 (D = 0.500 mm; Figure 9.5) or Endothyra? sp. ( $D=0.250 \mathrm{~mm}$; Figure 9.3).

\section{Genus NEOENDOTHYRA Reitlinger, 1965}

Type species. Neoendothyra reicheli Reitlinger, 1965.

\section{Neoendothyra sp.}

Figure 9.3?, 9.6

Remarks. We found only nine specimens ( $P 3$, $\mathrm{P} 7$ ?, P8?, P10, P14?, P18, P19, P20 and P25) of this genus, which is generally more common in other areas of Iran and in Armenia where it was initially described. One typical Neoendothyra sp. is illustrated (Figure 9.6); another illustrated specimen (Figure 9.3) is transitional between Endothyra and Neoendothyra (see above) due to the periphery rounded and then, only carinate at the semi- last whorl. This latter specimen is relatively anachronistic, because this evolutionary trend appears earlier in the Carnic Alps and South China; i.e., in the Sakmarian/Artinskian (Lin, 1985; Vachard and Krainer, 2001).

Superfamily PALAEOTEXTULARIOIDEA

Galloway, 1933 nom. translat. Habeeb, 1979

Family PALAEOTEXTULARIIDAE Galloway, 1933 nom. translat. Wedekind, 1937

Subfamily PALAEOTEXTULARIINAE Galloway, 1933

Figure 8.5-15

Remarks. The palaeotextulariins are relatively rare in our samples but represented by at least three genera. The species of these three genera are very abundant in the literature but all poorly characterized. Hence, we determined our taxa as: Deckerella sp. (Figure 8.1, 8.5-6, 8.11), Climacammina spp. (Figure 8.10-8.15), and Cribrogenerina spp. (Figure 8.7-9, 8.12).

Occurrence. Deckerella is latest Midian-Julfian (P41 and P55); Climacammina and Cribrogenerina are present in many samples (P3, P20, P21, P25, P34, P40, P41, P50, P52 and P55).

Superfamily GLOBIVALVULINOIDEA Reitlinger, 1950 nom. translat. Hance et al., 2011

Discussion. This group was previously denominated Biseriamminoidea but due to the poor definition and very rare re-findings of Biserammina Chernysheva, 1941, and to the establishment of phylogenetic lineages issued from Pseudotaxis Mamet, 1974b (Vachard et al., 2006; Hance et al., 2011), the superfamily Globivalvulinoidea was translated and re-described by Hance et al. (2011) according to the phylogenetic schemes of Gaillot and Vachard (2007).

Occurrence. ?Late Tournaisian; earliest Serpukhovian-late Changhsingian; cosmopolite or endemic.

Family GLOBIVALVULINIDAE Reitlinger, 1950 emend. Gaillot and Vachard, 2007

Description. Test biserial, entirely planispiral or initially trochospiral, or entirely uncoiled, or trochospiral becoming planispiral. Wall thin, dark, microgranular, eventually granular with inclusions of clearer carbonate particles, or differentiated into two, three or four layers. Endoskeletal folds or partitions lead to the formation of chamberlets. Oral tongue often present, occasionally passing to a siphon. Aperture terminal simple.

Included subfamilies. Four subfamilies: Globivalvulininae Reitlinger, 1950; Paraglobivalvulininae 
Gaillot and Vachard, 2007; Dagmaritinae Bozorgnia, 1973 (= Louisettitinae); and Paradagmaritinae Gaillot and Vachard, 2007.

Occurrence. Mississippian-Permian (latest Tournaisian-latest Changhsingian). The Pennsylvanian genera are rather cosmopolite, whereas the Permian ones are restricted to the Neo-Tethys.

Subfamily GLOBIVALVULININAE Reitlinger, 1950

Description. Small, medium or large globivalvulinid test, entirely biseriate and planispiral (rarely slightly trochospiral). Subglobular with lobate periphery. Valvula projection generally well-developed. Wall dark, microgranular, homogeneous to differentiated. Aperture simple protected by the valvular projection.

Occurrence. Middle Mississippian-latest Permian/ earliest Triassic; first Palaeo-Tethyan, this genus becomes cosmopolite after the late Bashkirian times.

Genus GLOBIVALVULINA Schubert, 1921

Type species. Valvulina bulloides Brady, 1876.

Description. Globivalvulinin with a wall microgranular, dark, homogeneous to more or less differentiated, with e.g., (a) with a yellowish pseudofibrous inner layer (G. mosquensis Reitlinger, 1950), (b) as a finely perforated, Omphalotis-like, greyish wall (Vachard and Beckary, 1991), (c) granular with clearer calcareous agglutinated particules (G. granulosa Reitlinger, 1950), (d) with an intermediary clear layer ("diaphanotheca" of the authors): G. bulloides (Brady) of the authors. Nevertheless, this differentiation generally does not affect all the chambers and/or correspond to fossildiagenetic features. Hence, it is not yet admitted as a generic or subgeneric criterion among the Globivalvulina lineages.

Occurrence. Late Mississippian (earliest Serpukhovian-latest Permian (Changhsingian); first, this genus is Palaeo-Tethyan; then (after the late Bahkirian period), it becomes cosmopolite. Presence for confirming in the earliest Triassic (see G. curiosa Gaillot, Vachard, Galfetti and Martini, 2009; see also the double PTB event of Song et al., 2011, 2013). The Early Mississippian species, with a possible FAD in the late Tournaisian, are generally poorly known and need some revisions.

Globivalvulina bulloides (Brady, 1876)

Figures 8.17, 8.19 (top), 9.15

1876 Valvulina bulloides Brady, p. 89-90, pl. 4, figs. 12-15.

1998 Globivalvulina du groupe G. bulloides (Brady); Pinard and Mamet, p. 118-
119, pl. 27, figs. 16-20, pl. 28, figs. 1-4, 5?, 6-11 (with synonymy).

2009 Globivalvulina bulloides (Brady); Song et al., fig. 7.29-35.

Description. G. bulloides is a subglobose species, medium-sized for the genus: $D=0.340-0.630 \mathrm{~mm}$; $w=0.185-0.350 \mathrm{~mm} ; \mathrm{w} / \mathrm{D}=0.54-0.56 ; \mathrm{p}=0.060$ $\mathrm{mm}$; and $\mathrm{s}=0.015-0.030 \mathrm{~mm}$. The well-developed clear median layer in the wall ("diaphanotheca"), warmly advocated by Armstrong and Mamet (1977) or Pinard and Mamet (1998), is in reality very faintly developed (Groves, 1988; Brenckle, 2005) and/or unconspicuous (Vachard et al., 2006; this work). The synonymy with G. moderata Reitlinger, 1949, proposed by Groves (1988), is possible but this species is obviously smaller $(D=0.270$ $0.365 \mathrm{~mm}$ ), and the Biseriella parva of this author (non sensu Chernysheva, 1948), with its diameter of $0.250-0.380 \mathrm{~mm}$, is more closely related to $G$. moderata. All these possible misinterpretations and synonyms might demonstrate that the genera Biseriella and Globivalvulina are not morphologically distinct; therefore, only a hypothetical difference in their wall structure might confirm their separation.

Occurrence. ?Serpukhovian; Bashkirian to latest Permian, cosmopolite. Common in many samples of Maku (P2, P13, P16, and P55).

Globivalvulina ex gr. bulloides (Brady, 1876)

Figures 8.18, 8.20, 9.9, 9.17, 10.7, 10.12

Description. A small species with a thinner wall and a higher last chamber than the typical specimens of this species, with also a plane apertural face and a relatively strong valvula. $D=0.465-$ $0.625 \mathrm{~mm} ; \mathrm{w}=0.325-0.550 \mathrm{~mm} ; \mathrm{w} / \mathrm{D}=0.43-0.83$; $\mathrm{p}=0.010 \mathrm{~mm} ; \mathrm{n}=1.5 ; \mathrm{h}=0.115 \mathrm{~mm} ; \mathrm{s}=0.007-$ $0.020 \mathrm{~mm}$. Our material resembles $\mathrm{G}$. bulloides sensu Groves, 1992 (pl. 4, figs. 17?-18) and G. ex gr. bulloides sensu Pinard and Mamet (1998, pl. 27, figs. 17-20).

Occurrence. Murgabian-Midian of Maku (P1, P6, P8, P9, P10, P11, P14, P16, P17, P18, P19, P20, P21, P23, P25, P27, P31, P32, P34, P35 and P39).

Globivalvulina cyprica Reichel, 1946

Figures 8.21-8.22, 10.1?, 10.2, 10.3?, 10.4, 10.5?, 10.6, 10.15?, 10.18?

1946 Globivalvulina cyprica Reichel, p. 553554, text-figs. 39 a-f.

non 2006b Globivalvulina cyprica Reichel; Kobayashi, p. 182-183, figs. 3.7, 3.113.15 (= Retroseptellina; and probably a new species of this genus). 


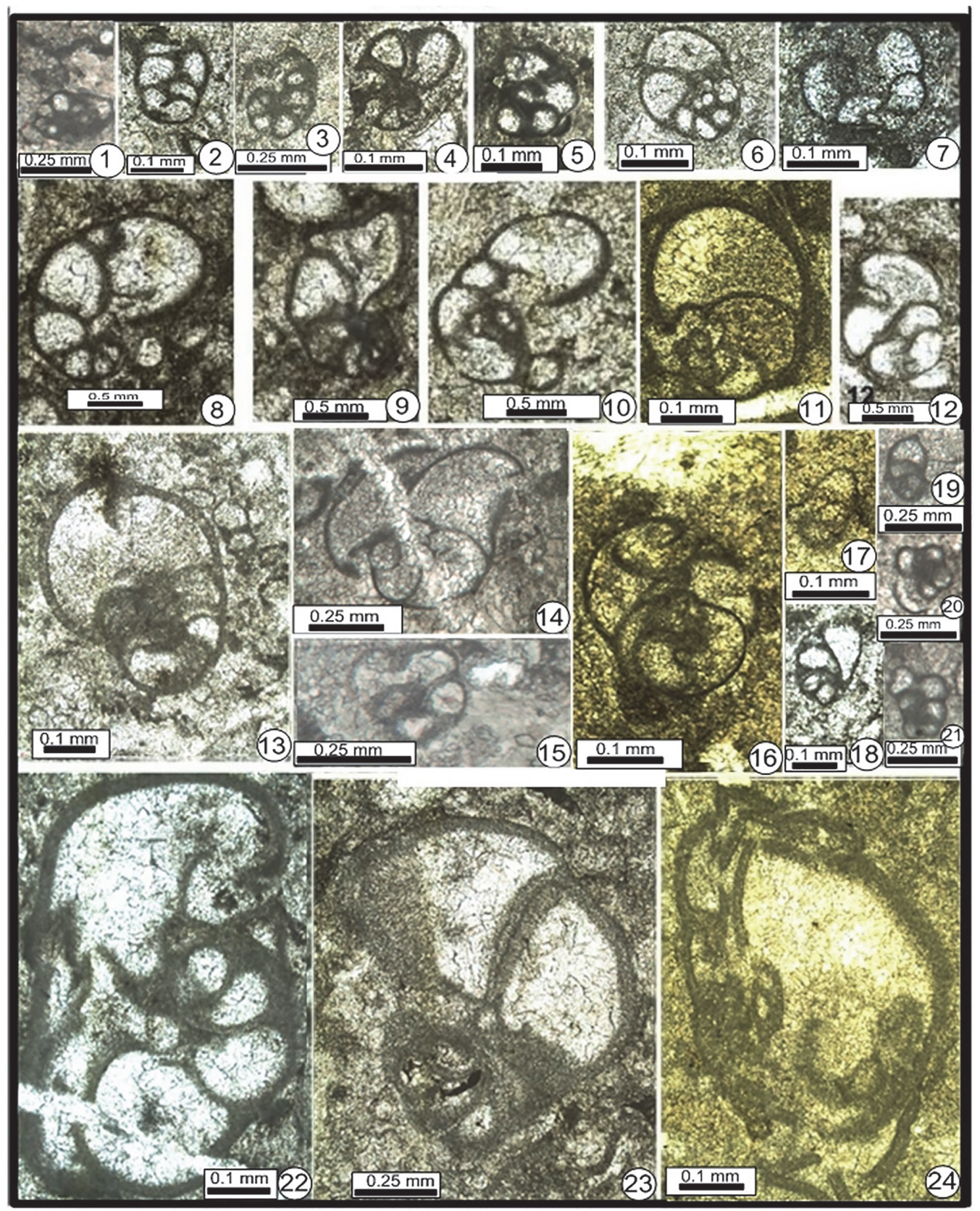

FIGURE 10. 1?, 2, 3?, 4, 5?, 6, 15, 18?. Globivalvulina cyprica Reichel, 1946. 1. Subtransverse section. P23. Murgabian. 2. Axial section. P22-34. Murgabian 3. Transverse section. P3-20. Murgabian. 4. Transverse section. P3-3. Murgabian. 5. Subtransverse section. P2-17. Murgabian. 6. Transverse section. P25-14. Murgabian. 15. Subtransverse section with Hemigordiellina sp. (top, right). P3. Murgabian. 18? Transverse section. P14-35. Murgabian. 7, 12. Globivalvulina ex gr. bulloides (Brady, 1876). 7. Axial section. P32-31. Midian. 12. Axial section. P1-7. Murgabian. 8-10. Globivalvulina graeca Reichel, 1946. 8. Transverse section. P16-23. Murgabian. 9. Transverse section. P16-34. Murgabian. 10. Axial section. P7-6. Murgabian. 11, 24. Paraglobivalvulina mira Reitlinger, 1965. 11. Axial section. Detail of a well preserved juvenarium surrounded by the fragments of the broken last chamber. P50-18. DjuIfian. 24. Broken axial? section. P50-29. Djulfian. 13-14, 22. Globivalvulina vonderschmitti Reichel, 1946. 13. Axial section. P10-53. Murgabian. 14. Axial section. P20-31. Murgabian. 21. Transverse section. P34-19. Midian. 14. Septoglobivalvulina distensa (Wang in Zhao et al., 1981). Transverse section. P22. Murgabian. 16. Rectoseptellina aff. nitida (Lin, Li and Sun, 1990). Axial section. P54-18. Djulfian. 17. Paradagmarita? sp. Oblique subaxial section. P5010. Djulfian. 19-21. Globivalvulina? sp. (Transitional from Globivalvulina to Paradagmarita). 19. Oblique section showing a last triangular chamber. P22. Murgabian. 20. Subaxial section. P22. Murgabian. 21. Subaxial section. P22. Murgabian. 23. Charliella? sp. 1. Subtransverse section. P16-40. Murgabian. 
2009 Globivalvulina cyprica Reichel; Ueno and Tsutsumi, figs. 8.5, 9.23.

?2009 Globivalvulina? sp.; Nestell et al., pl. 2, figs. 18-19.

? 2010 Globivalvulina cyprica Reichel; Altiner and Özkan Altiner, text-fig. 3, pl. 3, figs. 35-38.

2010 Globivalvulina cyprica Reichel; Ueno et al., figs. 4.12, 5.30.

Description. Test ovoid, small-sized, with oblong chambers; wall typically bilayered with an inner pseudofibrous layer in the last chambers. $D=$ $0.400-0.750 \mathrm{~mm} ; \mathrm{w}=0.210-0.325 \mathrm{~mm} ; \mathrm{w} / \mathrm{D}=0.74-$ $0.83 ; \mathrm{p}=0.020-0.030 \mathrm{~mm} ; \mathrm{n}=1-1.5 ; \mathrm{h}=0.085-$ $0.130 \mathrm{~mm} ; \mathrm{s}=0.010-0.020$ (rarely 0.040 ) $\mathrm{mm}$. The species generally attributed to G. cyprica in the Altiner's work (e.g., Altiner and Ozkan Altiner, 2010), is homeomorphous but its inner layer seems to be almost absent. Our specimens of Figure 8.1, 8.3, $8.5,8.15,8.18$ might correspond to this latter taxon. The Iranian specimen of Jenny-Deshusses (1983, pl. 6, fig. 8) is also misinterpreted and more similar to G. scaphoidea Reitlinger, 1950. The specimens of Kobayashi (1988a, pl. 1, figs. 29-32, from Japan) and those of Lin et al. (1990, pl. 11, figs. 11-16, from South China) belong to the group G. bulloides. Our specimens have a typical test profile (especially, with the very high semi-last whorl). The wall is slightly and sporadically bilamellar. Subsequently to the description of Reichel (1946), this species has been rarely correctly identified in the literature (e.g., Nguyen Duc Tien, 1979, 1986a; Altiner and Ozkan Altiner, 2010).

Occurrence. Murgabian/Midian of Cyprus. Midian of Turkey, Italy, Iran, Cambodgia, Sumatra, Malaysia; type Wuchiapingian of South China (Isozaki and Vachard, unpublished data); Lopingian of Yunnan. Our specimens have been encountered in the Murgabian of Maku (P2, P3, P9, P14?, P16, P17, P20, P23 and P25).

Globivalvulina graeca Reichel, 1946

Figures 8.19 (bottom), 8.23-8.26, 9.5, 9.7, 9.119.14, 10.8-10.10, 11.3-11.4

1946 Globivalvulina graeca Reichel, p. 550553 , text-figs. 36,38 , pl. 19 , figs. $15-$ 17.

?1981 Globivalvulina sp.; Okimura and Ishii, pl. 2, fig. 17.

1990 Globivalvulina graeca Reichel; Lin et al., p. 163, pl. 11, figs. 17-21 (with synonymy). v. 2005

Globivalvulina graeca Reichel; Vachard et al., p. 151, 153, pl. 3.1, 3.13 ? (with synonymy).

2010 Globivalvulina graeca Reichel; Angiolini et al., fig. 4.8-9.

Description. Test relatively large (diagnosis: $\mathrm{D}=$ $0.700-0.800 \mathrm{~mm}$ ), subglobular, slightly depressed on the apertural face. Wall bilayered with an inner pseudofibrous layer present in the majority of chambers. As obvious in our specimens (e.g., in Figures 8.23, 8.26), the thickness and development of the inner layer is variable and seems exclude the creation of a subgenus for the Globivalvulina with an inconsistent inner layer, contrary to other foraminiferal genera as among the Palaeotextulariidae for example, where this inner layer is present in all chambers. The parameters of our specimens are: $D=0.625-0.800 \mathrm{~mm} ; \mathrm{w}=0.550$ $0.640 \mathrm{~mm} ; \mathrm{w} / \mathrm{D}=0.71-0.91 ; \mathrm{p}=0.020-0.060 \mathrm{~mm} ; \mathrm{n}$ $=1.5 ; \mathrm{h}=0.200-0.250 \mathrm{~mm} ; \mathrm{s}=0.010-0.045 \mathrm{~mm}$.

Occurrence. Rare in late Early Permian (e.g., Artinskian of Slovenia (Kochansky-Devidé, 1970), Armenia (Akopian, 1974) and South China (Lin et al., 1990)). Common in Middle Permian and widespread in all the Palaeo-Tethys and Neo-Tethys: Greece, Italy, Austria, Tunisia, Hungary, Slovenia, Croatia, Montenegro, Turkey, Armenia, Iran (e.g., Kuh-e Jamal: Jenny-Deshusses, 1983b, pl. 6, fig. 1), Saudi Arabia, Afghanistan, Himalaya, Thailand, Malaysia, Cambodgia and South China. Rare in other Middle Permian ocean shelves, seamounts or insular microplates: New Zealand, Japan, and Greenland. Murgabian, Midian and Djulfian of Maku (P1, P2, P3, P4, P6, P7, P8 (relatively common), P10, P11, P12, P14, P15, P16, P17, P18, P19, P20, P21, P23, P25, P27, P30, P32, P34, P35(2), P36, P41, P52 and P54).

Globivalvulina vonderschmitti Reichel, 1946

Figures 9.15-17, 10.13-14, 10.22

1946 Globivalvulina vonderschmitti Reichel, p. 556 , figs. $37 a-e$.

1997 Globivalvulina vonderschmitti Reichel; Kobayashi, pl. 4, figs. 1-5.

2004 Globivalvulina vonderschmitti Reichel; Kobayashi, fig. 6.51.

v. 2005 Globivalvulina vonderschmitti Reichel; Vachard et al., p. 153, 154, pl. 3.2 (with synonymy).

v. 2005 Globivalvulina vonderschmitti Reichel; Hughes, pl. 2, figs. 17-20.

2009 Globivalvulina vonderschmitti Reichel; Song et al., fig. 8.20-22. 


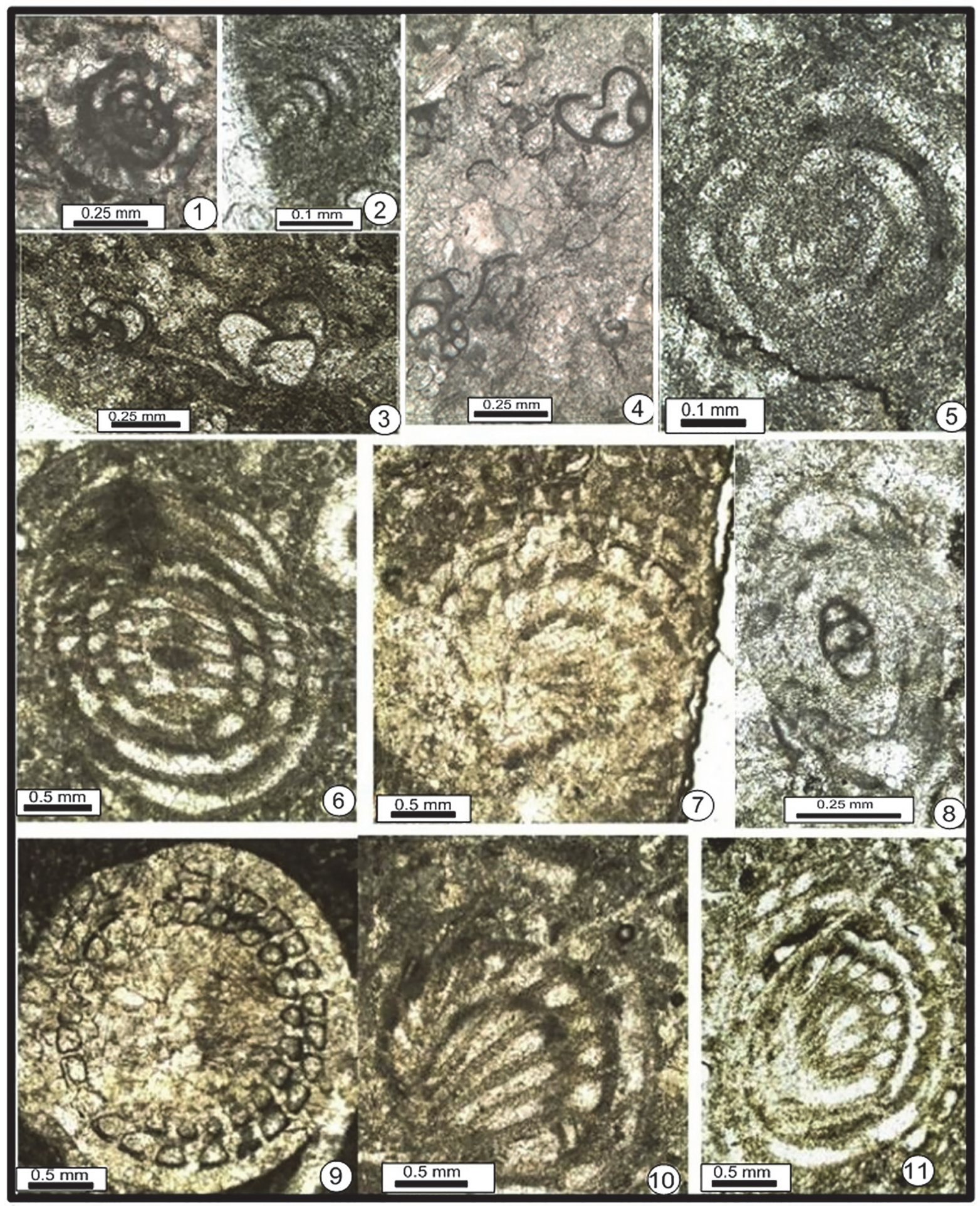

FIGURE 11. 1-2, 5. Sphaerulina sp. 1. 1. Subtransverse section. P2. Murgabian. 2. Axial section. P11-21. Murgabian 5. Axial section. P11-30. Murgabian. 3-4. Globivalvulina graeca Reichel, 1946. 3. Subaxial section (right) with Globivalvulina bulloides (left). P1-6. Murgabian. 4. Transverse section (bottom right) and subaxial section (top left). P22. Murgabian. 6-7, 10-11. Sphaerulina cf. zisongzhengensis Sheng, 1963. 6. Subaxial section. P11-21. Murgabian 7. Subtransverse section. P11-4. Murgabian. 10. Subtransverse section. P11-19. Murgabian 11. Subtransverse section. P1-25. Murgabian. 8. Nankinella sp. 2. Subaxial section with different stages of neosparitization. P6-61. Murgabian. 9. Sphaerulina sp. 3. Transverse section entirely microsparitized. P27-51. Murgabian. 
2009 Globivalvulina vonderschmitti Reichel; Ueno and Tsutsumi, fig. 9.22.

2010 Globivalvulina gigantea Filimonova, $p$. 804, 806, pl. 15, figs. 21-22.

? 2010 Globivalvulina vonderschmitti Reichel; Ueno et al., fig. 5.25.

Description. Large species $(D$ of type material $=$ 0.930-1.040 mm), subglobular with chambers increasing very rapidly in size, and a thick, well developed, bilayered wall. Similarly, our material is smaller that the typical specimens. $D=0.850-$ $0.950 \mathrm{~mm} ; \mathrm{w}=0.680-0.800 \mathrm{~mm} ; \mathrm{w} / \mathrm{D}=0.76-0.80$; $\mathrm{p}=0.040-0.065 \mathrm{~mm} ; \mathrm{h}=0.240-0.300 \mathrm{~mm} ; \mathrm{s}=$ 0.020-0.030 mm.

Remarks. As for G. graeca (see above), the thickness and development of the inner layer is variable and relatively inconsistent (e.g., in Figures 10.14n 10.22). Theoretically, the specimens of G. gigantea Filimonova, 2010 differ by "their greater size and wall structure," but the wall microstructure is identical, and the diameter of $G$. vonderschmitti measures $0.930-1.040 \mathrm{~mm}$ and that of G. gigantea, $0.900-1.550 \mathrm{~mm}$. Consequently, we suggest that these species are synonymous. Moreover, a part of the type material of G. gigantea comes from Armenia where G. vonderschmitti has been already mentioned by Kotlyar et al. (1989, pl. 2, fig. 27). In North America, G. guadalupensis Nestell and Nestell, $2006(=$ G. ex gr. vonderschmitti sensu Vachard et al., 1993c, pl. 8, figs. 2-3) might be a vicariant species.

Occurrence. Early Middle (Kubergandian)-Late Permian (Changhsinghian); widespread in all the Palaeo-Tethys and Neo-Tethys (Greece, Italy, Austria, Tunisia, Hungary, Slovenia, Croatia, Montenegro, Turkey, Saudi Arabia, Oman, Armenia, Iran (e.g., Bozorgnia, 1973, pl. 41, fig. 5; Lys et al., 1978, pl. 7, fig. 19; Partoazar, 1995, pl. 7, fig. 1), Afghanistan, Tajikistan, Himalaya, Pakistan, Sumatra, Thailand, Malaysia, Cambodgia and South China. Rare in Japan (Kobayashi, 1986, pl. 3, figs. 1-3; 1997, pl. 4, figs. 6-7). Rare specimens have been found in Murgabian- Djulfian of Maku (P6, P7, P8, P10?, P11, P16, P17, P20, P27, P29?, P34 and $\mathrm{P} 43$ ).

\section{Globivalvulina? sp.}

Figure 10.17-10.21

Description. Our material shows rare small, questionable Globivalvulina $(D=0.170-0.250 \mathrm{~mm}$ ), which begin to present triangular chambers, especially conspicuous in cross sections. These specimens might be the distant ancestors of the genus Paradagmarita and, in this case, might confirm the phylogenies proposed by Gaillot and Vachard (2007). However, other filiations were suggested, passing from Dagmarita to Paradagmarita (see Altiner, 1997 and Altiner and Özkan Altiner, 2010). Therefore, the independence of both subfamilies: Dagmaritinae and Paradagmaritinae, although admitted by us, is a debatable subject (D. Altiner, pers. comm., october 2013).

Occurrence. Murgabian of Maku (P3?, P11?, P14, $\mathrm{P} 22$, and P25).

Genus CHARLIELLA Altiner and Özkan-Altiner, 2001

Type species. Charliella rossae Altiner and Özkan-Altiner, 2001.

Description. Charliella is another variation on the globivalvulinid theme, characterized by a four-layered wall and triangular chambers. It constitutes the most advanced genus of the globivalvulinins sensu stricto.

Occurrence. Midian of Palaeo-Tethys and NeoTethys. Guadalupian of northern Mexico and Texas (USA). Djulfian of Zagros and Fars (Iran) and Abu Dhabi (see Gaillot and Vachard, 2007). Wuchiapingian of Yunnan (Ueno et al., 2010). ?Changhsingian of southern Tibet (Wang et al., 2010). ?Lopingian of Japan (Kobayashi, 2013, fig. 7.17?-7.18)

\section{Charliella? sp. 1}

Figure 10.23

?p. 1995 Paraglobivalvulina mira Reitlinger; Partoazar, pl. 1(1), fig. 7 only (no fig. 6 $=$ true Paraglobivalvulina mira).

Description. This atypical Charliella, globular, large-sized, with first chambers closely coiled, and a rapid increasing of the high of the semi-last whorl. First chambers triangular but the last ones appear similar to the last chambers of Globivalvulina vonderschmitti. Therefore, Charliella? sp. 1 appears perfectly transitional between Globivalvulina vonderschmitti and Charliella rossae. As an ancestral character, the chambers remain relatively globular and are not really triangular, and the differentiation of the wall is less complex. $D=0.720$ $0.895 \mathrm{~mm} ; \mathrm{w}=0.500-0.700 \mathrm{~mm} ; \mathrm{w} / \mathrm{D}=0.70-0.88$; number of whorls: $1.5 ; \mathrm{h}=0.250-0.270 \mathrm{~mm}$; number of chambers: 7 pairs; $\mathrm{s}=0.030-0.080 \mathrm{~mm}$.

Comparison. Similar to Globivalvulina vonderschmitti by the very large size and the shape of last chambers but differing a lot by the wall structure. The new species is larger than $C$. rossae and $C$. altineri Gaillot and Vachard, 2007, the two known species of the genus. 
Occurrence. Murgabian of Maku (P10, P16, P20 and P34).

Subfamily PARAGLOBIVALVULININAE Gaillot and Vachard, 2007

Remarks. We include in the subfamily the genera Labioglobivalvulina, Septoglobivalvulina and Retroseptellina, due to their trend to form spherical tests.

\section{Genus LABIOGLOBIVALVULINA Gaillot and Vachard, 2007}

Type species. Labioglobivalvulina baudi Gaillot and Vachard, 2007.

Description. Labioglobivalvulina is similar to Septoglobivalvulina but less globular and with a different aperture in elongate slit at the base of the chamber and not simple, more or less basal or areal in Septoglobivalvulina as in Globivalvulina.

Occurrence. Late Midian-Lopingian Palaeo-Tethys and Neo-Tethys. Discovered in the Murgabian of Maku.

Labioglobivalvulina cf. baudi Gaillot and Vachard, 2007

Figures 8.16, 9.17, 15.14

v. 2007 Labioglobivalvulina baudi Gaillot and Vachard, p. 54-55, pl. 4, figs. 2, 7?, 89,11 , pl. 12, figs. 8-10, pl. 28, figs. 4 , 6,11 , pl. 29, fig. 20, pl. 31, fig. 8?, pl. 35 , fig. 13 (with synonymy).

Description. Our specimens differ a little from typical $L$. baudi, by their relatively more globular shape. Moreover, they are Murgabian in age, although $L$. baudi was originally only encountered from latest Midian to Dorashamian and considered as especially characteristic of the Djulfian in Zagros and Fars regions in Iran (Gaillot and Vachard, 2007, p. 55). Consequently, (a) the importance of this taxon is lesser than that indicated by these authors; (b) Labioglobivalvulina might be also a junior synonym of Septoglobivalvulina.

Occurrence. Murgabian of Maku (P17 and P22).

Genus SEPTOGLOBIVALVULINA Lin, 1978 emend. Gaillot and Vachard, 2007

Type species. Septoglobivalvulina guangxiensis Lin, 1978.

Synonyms. Globivalvulina (part.); Paraglobivalvulina (part.).

Description. Globivalvulinin test with few whorls and few chambers with the last chamber increasing rapidly in height and width and often embracing partially or totally the preceeding chambers. Endoskeleton in the advanced species under the form of an incurved oral tongue. Wall microgranular unilayered. Aperture terminal simple.

Composition. Septoglobivalvulina guangxiensis Lin, 1978 ( $D=0.820-0.920 \mathrm{~mm}$ ); S. similis Lin, Li and Sun, 1990 ( $D=0.740-0.870 \mathrm{~mm}$ ); Globivalvulina distensa Wang in Zhao et al., 1981; G. globosa sensu Vachard et al., 2002 (probably a new species) non sensu Wang in Zhao et al., 1981 (= Retroseptellina).

Comparison. This genus differs (1) from Globivalvulina (see above) by the increasing in height and width of the last chamber becoming enveloping of the preceding coiled chambers; (2) from Retroseptellina (see below) by the shape of the septa plane and not curved backward, and the more marked increasing in height of the last chamber whereas the last chambers of Retroseptellina are wider; and (3) from Paraglobivalvulina Reitlinger, 1965 by the less spherical shape, the thin wall and the more rudimentary endoskeleton.

Occurrence. Early?-late Midian to Changhsingian: Oman, South China, ?Armenia, Turkey (Hazro), Iran (Zagros, Fars) and UAE (United Arabian Emirates).

Septoglobivalvulina distensa (Wang in Zhao et al., 1981)

Figures 9.8, 10.14

1981 Globivalvulina distensa Wang in Zhao et al., p. 48 (in Chinese), 75 (in English), pl. 2, figs. 1-3.

1985 Globivalvulina sp. of G. vonderschmitti group; Okimura et al., pl. 1, fig. 10.

1988a Paraglobivalvulina? sp.; Pronina, pl. 2, figs. 8-9.

1990 Globivalvulina laxa Lin, Li and Sun, p. 163-164, pl. 11, fig. 36 only (non figs. 35, 37-38 = globivalvulinid indet.).

2005 Paraglobivalvulina globulosa (sic, probably: globosa Wang); Hughes, pl. 2, figs. $22-23$ (non fig. $21=$ ?S. guangxiensis).

v. 2006 Septoglobivalvulina distensa (Wang in Zhao et al.); Gaillot, p.71, pl. I.4, fig. 5, pl. I.5, fig. 15 , pl. I.7, fig. 12, pl. I.17, fig. 12 , pl. I.37, fig. 9, pl. I.43, fig. 15, pl. II.8, figs. 1, 5, pl. II.9, fig. 1, pl. II.31, fig. 4 , pl. III.6, fig. 5, pl. III.15, fig. 14?, pl. III.16, fig. 5, pl. VI. 4, figs. 10-11, 16, pl. VI.5, fig. 18, pl. VI.6, fig. 21, pl. VII.2, figs. 2.

v. 2007 Septoglobivalvulina distensa (Wang in Zhao et al.); Gaillot and Vachard, p. 
59-60, pl. 1 , fig. 5 , pl. 3 , fig. 12 , pl. 4 , fig. 15 , pl. 5 , pl. 14 ?, pl. 7 , fig. 5 , pl. 12 , fig. 18 , pl. 15 , fig. 12 , pl. 17 , fig. 5 , pl. 27 , fig. 4 , pl. 28 , fig. 15 , pl. 29 , figs. $10-$ 11,16 , pl. 31 , fig. 9 , pl. 36 , fig. 1 , pl. 37, fig. 2, pl. 40, figs. 1,5 .

2011 Paraglobivalvulina; Song et al., fig. 6.29.

Description. Diameter $=0.500-1.000 \mathrm{~mm}$; width $=$ $0.960 \mathrm{~mm}$; $\mathrm{w} / \mathrm{D}=0.96$; number of volution: 1 ; number of chambers: $3-4$; proloculus diameter $=0.060$ $0.160 \mathrm{~mm}$; height of last chamber $=0.235-0.600$ $\mathrm{mm}$ (i.e., more than the half total diameter, generally $53 \%$ ); wall thickness $=0.015-0.030 \mathrm{~mm}$.

Comparison. Typical $S$. distensa are a little smaller $(D=0.500-0.700 \mathrm{~mm})$ and the last chamber occupies only one-third of the total diameter, but these variations are probably intraspecific. The specimens of Pronina (1988a, pl. 2, figs. 8-9) might be immature $S$. distensa.

Occurrence. Early?-late Midian to Changhsingian: Oman, South China, Turkey (Hazro), Iran (Zagros) (Gaillot, 2006). Late Changhsingian of South China and ?Armenia. Murgabian of Maku (P3, P5, P8, P10, P11, P14, P19, P20, P21, P22, and P27).

Genus RETROSEPTELLINA Gaillot and Vachard, 2007

Type species. Globivalvulina decrouezae Köylüoglu and Altiner, 1989.

Synonyms. Globivalvulina (part.); Septoglobivalvulina? sensu Vachard et al., 2005; Septoglobivalvulina (part.); Paraglobivalvulina (part.).

Description. Coiling similar to Globivalvulina, but with a more globular test and more depressed chambers, few whorls and few chambers per whorl, and a tendency of the increasing of the width of the chambers during the growth whereas their height is relatively constant. Septa strongly curved backward. Wall unilayered, thin and microgranular.

Composition. Globivalvulina globosa Wang in Zhao et al., 1981; G. decrouzae Köylüoglu and Altiner, 1989; Paraglobivalvulina nitida Lin, Li and Sun, 1990.

Discussion. The strong curvature of the septa backward generates a space announcing probably the additional chamberlets of Paraglobivalvulina Reitlinger, 1965 and Paraglobivalvulinoides Zaninetti and Jenny-Deshusses, 1985. By this character, Retroseptellina is transitional between the Globivalvulininae and the Paraglobivalvulininae.

Occurrence. Questionable in "early Murgabian" of Thailand (Ueno and Sakagami, 1993; in our opin- ion, these levels are Midian in age). Murgabian, Djulfian, Dorashamian of southern Turkey (e.g., Canuti et al., 1970 updated by Gaillot, 2006; Koylüoglu and Altiner, 1989; Unal et al., 2003); Thailand and Malaysia (Yanagida et al., 1988; Fontaine et al., 1993, 1994). Midian of Oman (Vachard et al., 2002). Latest Midian-earliest Djulfian of Armenia (Kotlyar et al., 1989). Midian of New Zealand (Vachard and Ferrière, 1991). Midian of central Japan (Kobayashi, 2006b). Dorashamian of Greece (Altiner and Özkan-Altiner, 1998; Baud et al., 1991; Grant et al., 1991). WuchiapingianChanghsingian of South China (Lin et al., 1990; Zhang and Hong, 2004). Wuchiapingian of northern Italy and Iran (Mohtat-Aghai and Vachard, 2005) Wuchiapingian of Yunnan (Ueno et al., 2010). Duhaysan Member (late Djulfian) of Saudi Arabia (Vachard et al., 2005). Changhsingian of NW Caucasus (Pronina-Nestell and Nestell, 2001). Changhsingian of Hungary (Théry et al., 2007) and southern Tibet (Wang et al., 2010). Lopingian of Japan (Kobayashi, 2013). Maku (P17, P27 and P54).

Retroseptellina aff. nitida (Lin, Li and Sun, 1990) Figure 10.16

1983b Globivalvulina vonderschmitti Reichel; Jenny-Deshusses, pl. 22, fig. 1.

?1990 Paraglobivalvulina nitida Lin, Li and Sun, p. 166, pl. 12, figs. 20-21.

1995 Paraglobivalvulina aff. mira Reitlinger; Partoazar, pl.1(3), fig. 6.

p. 2004 Globivalvulina globosa Wang; Zhang and Hong, p. 21, pl. 1, figs. 25-26 (only, no fig. $4=$ true Retroseptellina globosa).

?p. 2010 Retroseptellina nitida (Lin, Li and Sun); Wang et al., fig. 4. 25-26.

Description. Test medium sized, globular with semi-evolute last whorl. Proloculus not observed. The first whorl is similar to that of $R$. nitida, but the last one is deviated. The two last pairs of chambers are relatively equal and give a typical quadripartite aspect to the axial section. The valvular projection is high and curved. The septa are strongly curved backward. The wall is simple, thin, dark, microgranular. The aperture is an elongate slit at the base of the last chamber. $\mathrm{H}=0.500-0.620 \mathrm{~mm}$; w $=0.240-0.255 \mathrm{~mm} ; \mathrm{n}: 1.5$ whorl $\mathrm{h}=0.100-0.260$ $\mathrm{mm} ; \mathrm{s}=0.005-0.010 \mathrm{~mm}$.

Comparison. Typical $R$. nitida is larger for the same number of whorls and its profile is more globular. "Paraglobivalvulina" globosa sensu Pronina- 
Nestell and Nestell, 2001 (pl. 5, figs. 2-3) is probably synonym of these typical Rectoseptellina nitida. Òccurrence. Djulfian of Maku (Northwest Iran). The specimen illustrated by Jenny-Deshusses (1983) comes from the sample Nesen 42 from Alborz (northern Iran); the sample of Partoazar (1995) comes also from the Nesen Fm of central Alborz. Changhsingian of Fujian (South China).

Genus PARAGLOBIVALVULINA Reitlinger, 1965

Type species. Paraglobivalvulina mira Reitlinger, 1965.

Description. Medium-sized paraglobivalvulinins whose last whorls embraces completely the preceeding whorls. Additional interseptal stolons are present. Wall microgranular relatively thick but undifferentiated.

Remarks. Many "Paraglobivalvulina" of the literature (see for example, Kobayashi, 1997, pl. 4, figs. 1-5; Song et al., 2009, fig. 9.8-10) belong in reality to Paraglobivalvulinoides, a genus typical of the late Changhsingian.

Occurrence. Midian-Lopingian of Armenia, Turkey, Zagros, Fars, Alborz (Iran), NW Caucasus, Carnic Alps, Hungary, South China, Phillipines, ?Cyprus, Salt Range, Japan, and Thailand (Gaillot and Vachard, 2007).

Paraglobivalvulina mira Reitlinger, 1965

Figures 9.10, 10.11, 10.24

1965 Paraglobivalvulina mira Reitlinger, $p$. 65, pl. 1, figs. 13-14.

p. 1995 Paraglobivalvulina mira Reitlinger; Partoazar, pl. 1(1), fig. 6 (non fig. 7 $=$ ?Charliella? sp. 1), pl. 2(3), fig. 2.

1995 Paraglobivalvulina sp.; Partoazar, pl. 1(1), fig. 11.

2004 Paraglobivalvulina mira Reitlinger; Jenny et al., pl. 8, fig. 5 .

v. 2006 Paraglobivalvulina mira Reitlinger; Insalaco et al., pl. 2, fig. 6 .

v. 2007 Paraglobivalvulina mira Reitlinger; Gaillot and Vachard, p. 60-61, pl. 1, fig. 4, pl. 8 , fig. 6 , pl. 17 , figs. 18-19, pl. 18 , fig. 2 , pl. 32 , figs. $3-5,18-20$, pl. 34 , figs. $8,11-12$, pl. 36 , figs. $7-10$, pl. 39 , figs. 4-8 (with synonymy).

2010 Paraglobivalvulina sp.; Wang et al., fig. 4.18.

2010 Paraglobivalvulina aff. mira Reitlinger; Angiolini et al., fig. 4.10.

?2010 Urushtenella sp.; Wang et al., fig. 3.22.
Remark. All our specimens are broken; therefore, their measurements are a little smaller than those of the type material: $D=0.690-0.750 \mathrm{~mm} ; \mathrm{w}=$ $0.550-0.625 \mathrm{~mm} ; \mathrm{w} / \mathrm{D}=0.75-0.85 ; \mathrm{s}=0.025-0.040$ $\mathrm{mm}$. Some are questionably assigned to the species (P25, P50; Figure 10.24). Others have an initial part occasionally well-preserved (Figure 10.11).

Occurrence. Midian-Lopingian of Palaeo-Tethys and Neo-Tethys. Sporadic but common in samples P41 and P50 of Maku (Iran).

Subfamily DAGMARITINAE Bozorgnia, 1973 nom. translat. and emend. Gaillot and Vachard, 2007

Synonyms. Biseriamminidae Chernysheva, 1941 (pars); Globivalvulinidae Reitlinger, 1950 (pars); Louisettitinae Loeblich and Tappan, 1984; Louisettitidae nom. translat. Rauzer-Chernousova et al., 1996; dagmaritin-type biseriamminids sensu Altiner (1997, text-fig. 1 p. 3).

Description. Globivalvulinidae uncoiled biseriate (or exceptionally biserially coiled). Undivided or divided chambers, often with horn-like lateral expansions. Aperture basal simple with a valvula.

Composition. Dagmarita Reitlinger, 1965; Sengoerina Altiner, 1999; Crescentia Ciarapica, Cirilli, Martini and Zaninetti, 1986; Labiodagmarita Gaillot and Vachard, 2007; Bidagmarita Gaillot et al., 2009; Louisettita Altiner and Brönnimann, 1980; Danielita Altiner and Özkan Altiner, 2010.

Remarks. This subfamily corresponds to the lineage of Dagmarita, from the ancestor (Murgabian) Sengoerina to the last avatar (Changhsingian) Louisettita. This evolution is remarkably homogeneous from the loss of the coiling to the emergence of an endoskeleton; hence, the addition of taxa like Louisettitinae or Louisettitidae, as suggested by Loeblich and Tappan $(1984,1987)$, does not make sense. Sengoerina is transitional between Globivalvulina cyprica and Dagmarita according to the phylogeny reconstructed by Altiner (1997). Crescentia may be considered as a return to planispiral coilings. The group of Paradagmarita constitutes a second derivation from $G$. cyprica; that of the Paradagmaritinae.

Occurrence. Murgabian to latest Changhsingian; Palaeo-Tethyan and Neo-Tethyan.

\section{Genus DAGMARITA Reitlinger, 1965}

Type species. Dagmarita chanakchiensis Reitlinger, 1965.

Description. Test entirely biseriate (excepted maybe the three initial chambers more or less globivalvulinid in shape). Spines ("horny-like expansions") developed on the upper outer lateral side of the chambers. Oral tongue located at the distal 
extremity of septum. Wall single microgranular mono-, double- or trilayered. Aperture terminal basal.

Occurrence. Early Murgabian (Vachard, 1980) and/or early Maokouan (Lin et al., 1990) to latest Changhsingian (Zhao et al., 1981; Lin et al., 1990) of Palaeo-Tethys and Neo-Tethys: Italy, Montenegro, the Carnic Alps, Hungary, western Turkey, eastern Taurus, Hazro, Armenia, central Alborz (Bozorgnia, 1973; Jenny-Deshusses, 1983); central Iran (Mohtat-Aghai and Vachard, 2003); Lopingian of Zagros and Fars (Gaillot, 2006); central Afghanistan, Salt Range (Pakistan), Ladakh (Himalaya), South China, West Thailand, northwestern Thailand, Malaysia, Philippines, Cambodgia, Primorye and Japan.

Dagmarita aff. elegans Sosnina in Sosnina and Nikitina, 1977

Figure 12.1-6

1977 Dagmarita elegans Sosnina in Sosnina and Nikitina, p. 50, pl. 2, fig. 8.

Remarks. As in Afghanistan, these Dagmarita correspond probably to the oldest representatives of this genus whose FAD can be definitively emplaced in the early Murgabian. Their wall is monolayered, dark and microgranular.

Occurrence. Rare small specimens have been observed in the Murgabian of Maku (P3, P6, P10, P11, P14, P18, P19, P20, P23, and P25).

Dagmarita altilis Wang in Zhao et al., 1981 Figure 12.9

1981 Dagmarita altilis Wang in Zhao et al., p. 47, 74, pl. 1, fig. 21.

1988a Dagmarita altilis Wang in Zhao et al.; Pronina, pl. 2, figs. 10-11.

1989 Dagmarita altilis Wang in Zhao et al.; Pronina in Kotlyar et al., pl. 1, figs. 1011.

1990 Dagmarita altilis Wang in Zhao et al.; Lin et al., p. 122, pl. 2, fig. 20-22.

v. 2006 Dagmarita altilis Wang in Zhao et al.; Insalaco et al., p. 122, pl. 2, fig. 2.

v. 2007 Dagmarita altilis Wang in Zhao et al.; Gaillot and Vachard, p. 65-66, pl. 1, figs. $10-11$, pl. 5 , figs. $3,8,17$, pl. 15 , fig. 15 , pl. 17 , figs. 1,8 , pl. 27 , figs. 5 , 9, pl. 34, fig. 10, pl. 37, fig. 19, pl. 38 , fig. 14 ?, pl. 45 , fig. 1 , pl. 47 , figs. $12-13$ (with synonymy).

Description. There are only four specimens perfectly typical of this Chinese species re-analyzed in
Gaillot and Vachard (2007), the wall of which is also microgranular.

Occurrence. Murgabian-Lopingian of South China. Lopingian of Zagros, Fars, Turkey and Abu Dhabi. Changhsingian of Armenia. Murgabian-Midian of Maku (P17, P27, P34 and P41).

Dagmarita? shahrezaensis Mohtat-Aghai and Vachard, 2003

Figure 12.7-12.8

v. 2003 Dagmarita shahrezaensis MohtatAghai and Vachard, p. 38-40, pl. 1, figs. 1-13, 14? (with synonymy).

v. 2005 Dagmarita shahrezaensis MohtatAghai and Vachard; Mohtat-Aghai and Vachard, pl. 2, figs. 21-22, pl. 3, fig. 5.

v. 2007 Dagmarita? shahrezaensis MohtatAghai and Vachard; Gaillot and Vachard, p. 66, pl. 12, figs. 1, 19, pl. 31 , fig. 16 , pl. 35 , fig. 9 , pl. 37 , fig. 18 ? (with synonymy).

Description. This atypical Dagmarita is devoid of horny protuberances. It might represent another ancestor candidate of Paradagmarita.

Occurrence. Late Midian-Changhsingian of Zagros and Taurus. Late Wuchiapingian-?Changhsingian of central Iran, Himalaya, Armenia, South China and Malaysia. Questionable in early Changsinghian of Saudi Arabia and late Changhsingian of Primorye. Murgabian-Midian of Maku (P25, P40 and P41).

\section{Subfamily PARADAGMARITINAE Gaillot and Vachard, 2007}

Description. A subfamily of Globivalvulinidae (i.e., with a biserially coiled growth and a microgranular wall, occasionally differentiated) characterized by an uncoiling more or less developed after an initial coiling generally slightly trochospiral.

Composition. Paradagmarita Lys in Lys and Marcoux, 1978; Paradagmaritopsis Gaillot and Vachard, 2007; Paradagmaritella Gaillot and Vachard, 2007; Paradagmacrusta Vachard and Gaillot, 2007; Paremiratella Gaillot and Vachard, 2007.

Discussion. According to Altiner and Özcan-Altiner (2010), the genera Paradagmaritopsis; Paradagmaritella; Paremiratella are not phylogenetically related to Paradagmarita and its ancestors. Nevertheless, we do not find, during our study, any new data in order to modify the assignments of Gaillot and Vachard (2007). Paradagmaritinae differ from Globivalvulininae by the terminal uncoiled part of the test; they differ from 


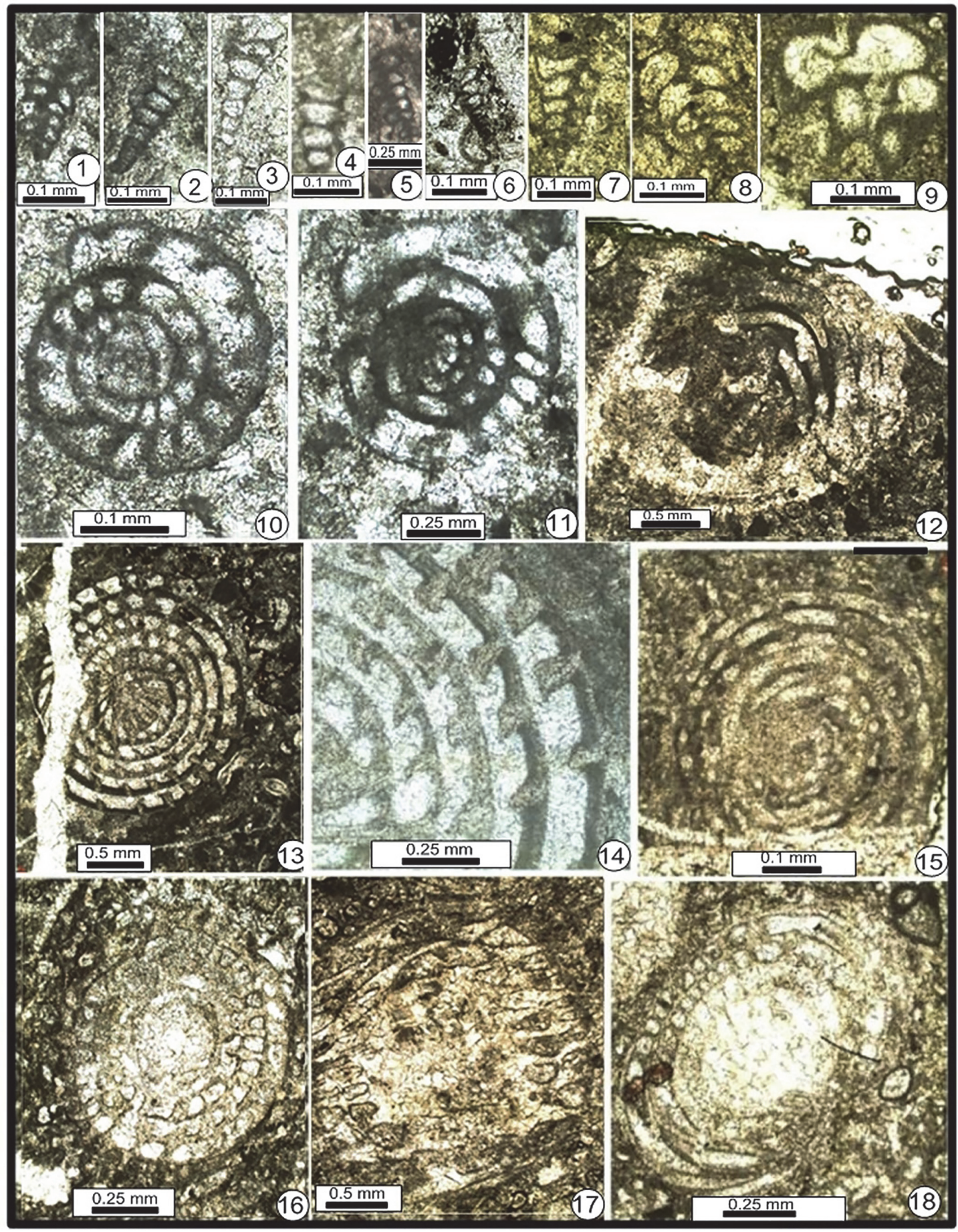

FIGURE 12. 1-6. Dagmarita aff. elegans Sosnina in Sosnina and Nikitina, 1977. 1. Axial section. P14-37. Murgabian. 2. Oblique section. P18-6. Murgabian. 3. Oblique section. P25-7. Murgabian. 4. Oblique section. P10-61. Murgabian. 5. Axial section. P2. Murgabian. 6. Subaxial section. P6-60. Murgabian. 7-8. Dagmarita? sharezaensis MohtatAghai and Vachard, 2003. 7. Subaxial section. P40-56. Midian. 8. Axial section. P40-28. Late Midian. 9. Dagmarita altilis Wang in Zhao et al., 1981. Axial section. P41-78. Latest Midian. 10-11, 12?. Sphaerulina sp. 1. 10. Transverse section. P18-20. Murgabian. 11. Subtransverse section. P14-54. Murgabian. 12. Subaxial section with developed chomata. P14-3. Murgabian. 13-15. Sphaerulina cf. zisongzhengensis Sheng, 1963. 13. Subtransverse section. P32-1. Midian. 14. Detail of a transverse section showing the typical recrystallization of the wall. P32-20. Midian 15. Subaxial section. P11-8. Murgabian. 16-17, 18? Sphaerulina sp. 3. 16. Subtransverse section. P1-26. Murgabian. 17. Subaxial section. P6-47. Midian. 18? Oblique section. P16-52. Murgabian. 
Dagmaritininae (= Louisettitinae) by the initial coiled part. No evidence of the phylogenic filiation between Dagmarita and Paradagmarita (as proposed by Altiner, 1997) has been observed in our material. A filiation from Globivalvulina seems to be more likely (see the specimens illustrated by Okimura et al., 1985, pl. 1, fig. 16, and BerczkiMakk et al., 1995, pl. 6, fig. 4), and eventually, those discovered in this study (Figure 10.19-10.20; see discussion above).

Occurrence. Lopingian, probably limited to the western Neo-Tethys (although questionably quoted from southern Italy to Thailand).

Genus PARADAGMARITA Lys in Lys and Marcoux, 1978 emend. Gaillot and Vachard, 2007

Type species. Paradagmarita monodi Lys in Lys and Marcoux, 1978.

Description. Small to medium-sized globivalvulinid paradagmaritin characterized by an early stage enrolled, biserial, involute, slightly trochospiral, and a later uncoiled, biserial stage, relatively long. Wall dark, microgranular, relatively thin, uni- or multilayered. Chambers inflated. Aperture simple, terminal, interio-marginal with a valvula.

Occurrence. Late Djulfian-Dorashamian. PalaeoTethyan and Neo-Tethyan, principally known in Turkey (Taurus), Iran (Zagros), Saudi Arabia (Vachard et al., 2005) and Armenia (Pronina-Nestell and Nestell, 2001), but mentioned (probably erroneously) from Italy to Japan (e.g., Jenny and Stampfli, 2000, p. 32). The Paradagmarita from Afghanistan described by Vachard (1980) are the westernmost representatives of this genus. Despite it seems likely that true Paradagmarita are present also in South China (Gaillot et al., 2009). The "Paradagmarita" from Thailand and Pakistan are very different and probably are derived from Charliella. The "Paradagmarita" from Japan (Kobayashi, 1997b, 2004) belong to Paradagmaritopsis, a genus also present in South China (Gaillot et al., 2009).

Paradagmarita? sp.

Figure 10.17-10.19

? 1985 Paradagmarita sp. of P. monodi group; Okimura et al., pl. 1, fig. 16 (the magnification indicated seems to be erroneous).

?p. 1988 Globivalvulina sp. 1; Pronina, pl. 2, fig. 6 (no fig. $5=$ Labioglobivalvulina baudi).
? 1988 Globivalvulina sp. 2; Pronina, pl. 2, fig. 7.

Description. Test small, planispiral to trochospiral but the uncoiling of the test is not yet clearly marked. However, the aperture simple, terminal, interio-marginal with a valvula (V-shaped) is clearly recognisable. Wall dark, microgranular, trilayered with a clear intermediary layer. Chambers inflated. They differ from an ancestral globivalvuline by more triangular to quadrate chambers in transverse section and more angular chambers in axial section.

Dimensions. Height $=0.200-0.400 \mathrm{~mm}$; width $=$ $0.220-0.240 \mathrm{~mm}$; ratio $=0.73$; number of uncoiled chambers: $3-4$ pairs; height of last chamber $=$ $0.100-0.160 \mathrm{~mm}$; wall thickness $=0.010-0.020$ $\mathrm{mm}$.

Occurrence. ?Changhsingian of Armenia. Lopingian of Zagros and Fars (southern Iran; Gaillot, 2006). Wuchiapingian of Hazro (Turkey). Djulfian of Maku (P40?, P50, and P51).

Subclass FUSULINANA Fursenko, 1958 nom. translat. Vachard et al., 2010

Order FUSULINIDA Wedekind, 1937

Superfamily STAFFELLOIDEA Miklukho-Maklay, 1949 nom. translat. Solovieva, 1978

Family STAFFELLIDAE Miklukho-Maklay, 1949 Genus SPHAERULINA Lee, 1933

Type species. Sphaerulina crassispira Lee, 1933. Description. Test large, subspherical, planispiral, early whorls about the subspherical proloculus have short axis and lenticular test (like in Nankinella), later whorls with somewhat lengthened axis and spherical test or with slightly depressed umbilici (like in Staffella). Septa plane. Wall thick, probably originally aragonitic, microgranular, dark and finely perforate, often recrystallized in whitish granular microsparite. Single tunnel, chomata low and asymmetrical, sloping gently toward the poles.

Remarks. Although our specimens are abundant, we have observed few well-oriented sections. Moreover, the species described in the literature are very abundant and generally poorly discriminated. Consequently, we remain our specimens in open nomenclaure. Nevertheless, three groups of sections may be characterized, Sphaerulina sp. 1, S. cf. zisongzhengensis Sheng, 1963, and S. sp. 3, respectively.

Occurrence. Late Permian (Lopingian); South China; Yunnan; Japan; Uzbekistan (SE Pamir); NW Iran, Armenia, Turkey, Croatia, Carnic Alps and Italy. 
Sphaerulina sp. 1

Figures 11.1-11.2, 11.5, 11.12?, 12.10-12.11, $12.12 ?$

Description. Test relatively small for the genus, planispirally coiled, involute nautiloid, with a rounded periphery. Chomata usually faint to absent. The principal character of this staffellid is constituted by the wall microstructure, well-preserved, microgranular and dark. This taxon is possibly identical to Sphaerulina iranensis Kobayashi and Ishii, 2003 (see also Leven and Gorgij, 2011), or related to S. croatica (Kochansky-Devidé, 1965). An atypical specimen exhibits well-developed chomata (Figure 12.12). It corresponds eventually to another taxon.

Occurrence. Early Murgabian-Djulfian of Maku (P1, P6, P8, P9, P14, P16, P17, P18, P19, P20, $\mathrm{P} 23, \mathrm{P} 25, \mathrm{P} 26, \mathrm{P} 30, \mathrm{P} 32, \mathrm{P} 34$ and P48).

Sphaerulina cf. zisongzhengensis Sheng, 1963

Figures 11.6-11.7, 11.10-11.11, 12.13-12.15

1963 Sphaerulina zisongzhengensis Sheng, p. 153-154, pl. 2, figs. 6-7.

1967 Staffella zisongzhengensis (Sheng); Leven, p. 125-126, pl. 1, figs. 6-8.

2004 Staffella zisongzhengensis (Sheng); Jenny et al., pl. 7, fig. 5 .

2012 Sphaerulina zisongzhengensis Sheng; Chang et al., pl. 2, fig. 1.

Description. Test relatively similar to Staffella but larger and almost spherical. The diameter is moderate to large. No chomata. The principal character of this species (well illustrated by Leven, 1967) is constituted by the wall microstructure: the original dark wall remains well-preserved, while the septa become microsparitized and, by constrast, appear whitish (see especially Figure 12.14).

Occurrence. Middle-Late Permian of South China, SE Pamir, Oman, Greece, Turkey and MurgabianDjulfian of Maku (P11, P14, P15, P16, P34 and P55).

\section{Sphaerulina sp. 3}

Figures 11.9, 12.16-17, 12.18?

Description. Test spherical to ovoid. The diameter is moderate. The chomata are faint to absent. The wall is generally microsparitized but the microsparitization is generally not complete and do not affect the last whorls. S. ogbinensis Rozovskaya, 1965 is relatively similar to this taxon (see also Staffella sp. sensu Partoazar, 1995, pl. 3(1), fig. 9, and Sphaerulina cf. ogbinensis sensu Leven, 1997, p. 58, pl. 1, fig. 8). S. ogbinensis was described in the
Midian of Armenia and is also known in the Midian of Oman and southern Afghanistan.

Occurrence. S. sp. 3 was rarely found in our Midian samples of Maku (?P32 and P37).

Genus NANKINELLA Lee, 1933

Type species. Staffella discoides Lee, 1933.

Description. Schwagerinidae lenticular, discoidal or rhomboidal up to $6 \mathrm{~mm}$ in diameter, poles rounded to umbilicate, early stage with angular to rounded periphery, later more angular, up to 14 whorls in the adult. Septa and walls typical of the family (see Staffella), median crescentic tunnel and distinct chomata. Wall probably originally aragonitic, microgranular, dark and finely perforate, often recrystallized in whitish granular microsparite.

Occurrence. Early Bashkirian to latest Permian (late Changhsingian); China; Japan; Russia (North Urals, Caucasus); Ukraine (Crimea); Armenia; Croatia; Turkey; Greece; Vietnam; North America.

Nankinella ex gr. minor Sheng, 1955

Figures 11.8, 13.1-4

$1955 \quad$ Nankinella minor Sheng, p. 291, pl. 1, fig. 7.

v. 2005 Nankinella minor Sheng; Mohtat-Aghai and Vachard, pl. 2, figs. 8-9.

2009 Nankinella minor Sheng; Song et al., fig. 9.6-7.

Description. Test relatively small for the genus, planispirally coiled, involute nautiloid, with rounded periphery. Chomata faint to absent. Wall generally well preserved, microgranular and dark.

Occurrence. Murgabian to Djulfian of Maku (P1, P3, P7, P9, P10, P12, P16, P17, P19 P20, P23, P24, P25, P27, P34, P39, P40, P44, P50 and P51).

Nankinella sp. 2

Figure 13.5?-13.6, 13.8

Description. Test moderate in size, weakly (Figure 13.8) to strongly recrystallized (Figure 11.6); occasionally slightly biumbilicate (Figure 13.6, 13.8). Our specimens resemble those illustrated by Zhang et al. (2010, p. 961-962, 965, 966, fig. 5-3-5; and 2012 , p. 145,146 , fig. $4 \mathrm{~K}-\mathrm{O}$ ) but relatively different of the type material of Sheng $(1963$, p. 32 , 156-157, pl. 3, figs. 7-15).

Occurrence. Murgabian-Midian of Maku (P3, P6, P11, P17, P23, P34 and P40).

\section{Nankinella sp. 3}

Figure 13.7

Description. Test moderate to large. Strongly recrystallized, except or the central part of the test. Number of whorls relatively high: 8-9.5. The carina 


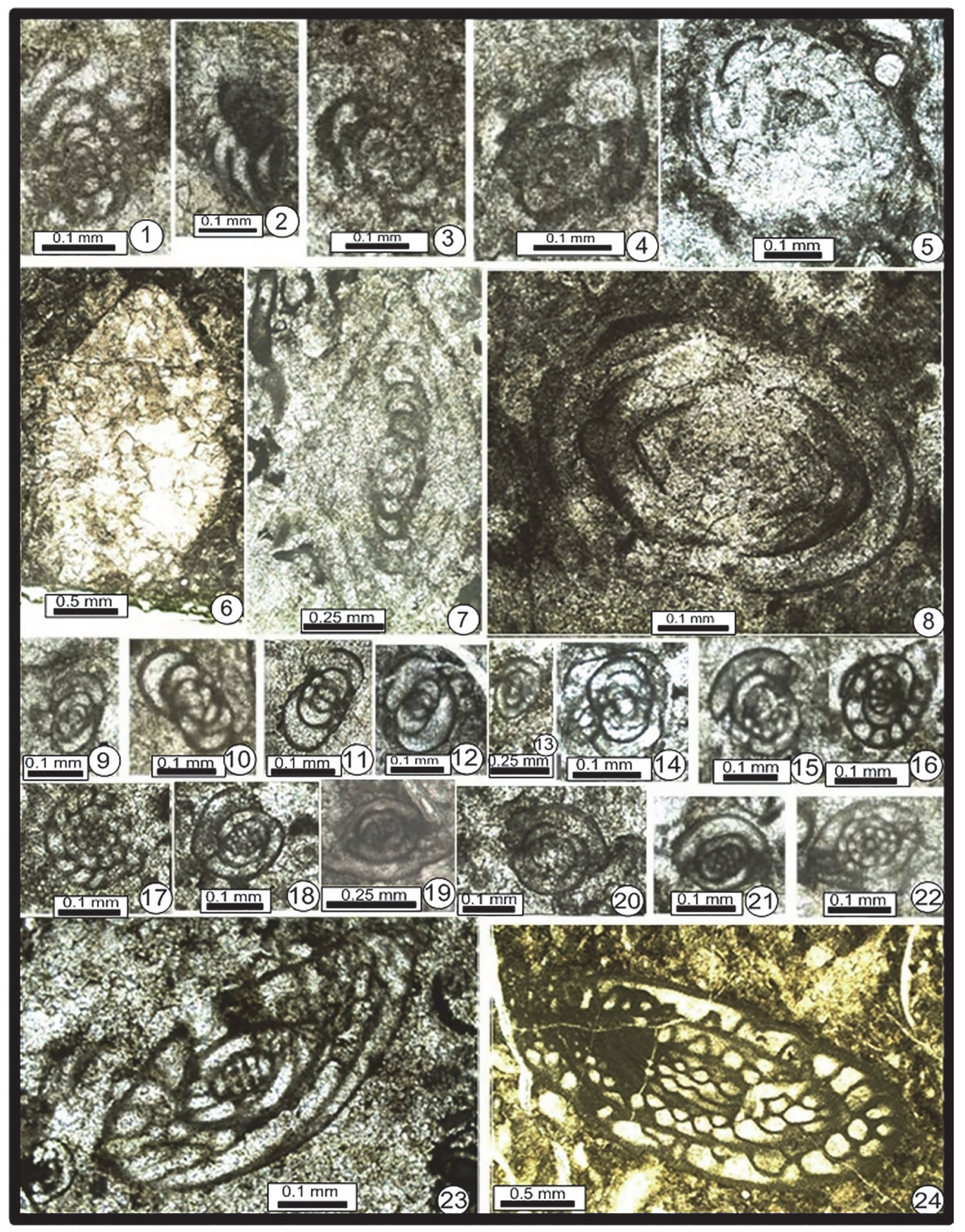

FIGURE 13. 1-4. Nankinella ex gr. minor Sheng, 1955.1. Subtransverse section. P10-6. Murgabian. 2. Oblique tranverse. P19-13. Murgabian. 3. Subaxial section. P17-34. Murgabian. 4. Subaxial section. P17-29. Murgabian. 5?-6, 8. Nankinella sp. 2. 5. Transverse oblique recrystallized section. P23-17. Murgabian. 6. Completely microsparitized section. P34-1. Midian. 8. Partially recrystallized axial section. P17-6. Murgabian. 7. Nankinella sp. 3. Axial section. P61. Murgabian. 9-12. Grovesella? ciryi Ebrahim Nejad and Vachard n. sp. 9. Paratype. Subaxial section. P17-30. Murgabian. 10. Holotype. Axial section. P10-8. Murgabian. 11. Paratype. Subaxial section. P22-11. Murgabian. 12. Paratype. Subaxial section with very enveloping last whorl. P34-16. Midian. 13-16. Grovesella sp. 13. Small axial section. P1-21. Murgabian. 14. Axial section. P14-24. Murgabian. 15. Subaxial section. P14-8. Murgabian. 16. Transverse section. P6-24. Murgabian. 7-22. Schubertella sp. 17. Transverse section. P22-19. Murgabian. 18. Axial section. P14-14. Murgabian. 19. Axial section. P2. Murgabian. 20. Axial section. P14-41. Murgabian. 21. Axial section. P2-21. Murgabian. 22. Axial section. P3-29. Murgabian. 23. Dunbarula aff. pusilla Skinner, 1969. Subaxial section. P30-12. Earliest Midian. 24. Chusenella sp. Subaxial section showing the septal folding. P41-54. Latest Midian. 
is well developed, and, by this character, our material resembles Nankinella acuta Rui, 1979 (p. 283, pl. 1, figs. 9-10), but the other parameters are too different to permit an assignment to this latter species.

Occurrence. Murgabian of Maku (P3 and P6).

Superfamily SCHUBERTELLOIDEA Skinner, 1931 nom. translat. Vachard in Vachard et al., 1993a

Remark. This superfamily encompasses the shortly fusiform fusulinids displaying a wall composed of a tectum and a protheca, and their ancestors with microgranular walls.

Family SCHUBERTELLIDAE Skinner, 1931 nom. translat Miklukho-Maklay et al., 1958

Subfamily SCHUBERTELLINAE Skinner, 1931 Genus SCHUBERTELLA Staff and Wedekind, 1910 emend. Sheng, 1963

Type species. Schubertella transitoria Staff and Wedekind

Description. See Shen (1963, p. 158).

Remarks. As Schubertella given rise to many lineages, many subgenera and/or genera might be created with the schubertellid ancestors, generally included in Schubertella sensu lato (a taxon which currently could include approximately 200 registered species). Apparently, the genera Grovesella Davydov and Arefifard, 2007 and Praedunbarula Vachard in Kolodka et al., 2012, both matched an attempt to individualize different trends in the genus Schubertella. However, Davydov and Arefifard (2013, p. 19) have written: "The morphology of the new genus Praedunbarula, in our opinion, is perfectly consistent with long-ranging Schubertella, indicating that the proposed age of the Praedunbarula Biozone is therefore questionable." Consequently, we deduced that our "dialectic" interpretation of Grovesella was erroneous. Furthermore, in our opinion, the phylogenies of Leven (2010) and Davydov (2011) established principally in using Grovesella and Zarodella Sosnina, 1981, and only based on the test morphologies (often convergent among the primitive fusulinids), are totally opposed to the wall microstructure analyses. For instance, the Bashikirian taxa have a microgranular dark wall, other representatives of the proposed lineage have a schubertelloid wall (i.e., tectum plus protheca), whereas Zarodella has a recrystallized wall (characteristic of the staffelloids), and, finally, all are given as ancestors of Pamirina Leven, 1970, which is a primitive Neoschwagerinoidea (i.e., a taxon with a fine keriothecal wall). Therefore, in the phylogeny proposed by Leven (2010), are closely linked in the same lin- eage, all the microstructures of walls of the order Fusulinida, considered by us as suprafamiliar characters (and even as order characters by some Russiuan authors: see Rauzer-Chernousova et al., 1996). In conclusion, a revision of the taxa included in Schubertella sensu lato remains necessary, but it starts pretty bad.

Occurrence. Typical Schubertella are distributed globally in all the palaeotropical areas, from Moscovian to Wordian (Rauzer-Chernousova et al., 1951; Skinner and Wilde, 1966; Leven, 1998a, b). Bashkirian-early Moscovian forms, because of their dark microgranular wall, belong more probably to the genus Schubertina Marshall, 1969 emend. Davydov, 2011 (= Eoschubertella Thompson, 1937 of the authors, non Thompson, 1937), whereas typical representatives are distributed from late Moscovian to latest Permian.

Schubertella sp.

Figure 13.17-13.22

Description. Test small, up to about $1.500 \mathrm{~mm}$ in length, early stage discoidal, later stage with sharply changed axis of coiling and becoming fusiform with acute poles, septa numerous, unfluted, or with slight fluting at the poles of the outer whorls; wall composed of tectum and protheca, chomata low, asymmetrical and bordering a broad low tunnel.

Occurrence. Murgabian, Midian, and Djulfian of Maku (P2, P3, P14, P16, P19, P20, P21, P25, P26, $\mathrm{P} 30, \mathrm{P} 39$ and P52).

Genus GROVESELLA Davydov and Arefifard, 2007

Type species. Grovesella tabasensis Davydov and Arefifard, 2007.

Diagnosis of Davydov and Arefifard (2007, p. 6). Test very small to moderate in size for this group of schubertellids discoidal to nautiloid or nearly globular, with broadly rounded periphery and weakly to mildly umbilicate flanks. Coiling skewed in initial one or two volutions or can be nearly straight. Length of the test is equal or less than width and consequently the means of form ratio is equal or less than one. Wall thin, poorly visible, most probably two layered with darker and thin tectum and slightly lighter, structureless primatheca. Chomata not observed in type species, but present in the Pennsylvanian representatives of the genus.

Composition (of Davydov and Arefifard (2007, p. 6)). Grovesella mosquensis (Rauzer-Chernousova in Rauzer-Chernousova et al., 1951); Grovesella compressa (Rauzer-Chernousova in Rauzer-Chernousova et al., 1951); Grovesella miranda (Leon- 
tovich in Rauzer-Chernousova et al., 1951); Grovesella globulosa (Safonova in Rauzer-Chernousova et al., 1951); Grovesella pseudoglobulosa (Safonova in Rauzer-Chernousova et al., 1951); Grovesella borealis (Rauzer-Chernousova in Rauzer-Chernousova et al., 1951).

Remarks. In reality, it is clear that the original diagnosis includes all the small, nautiloid to nearly globular schubertellids with a form ratio equal to, or less than 1.0. The primatheca mentioned in this diagnosis is probably a synonym of protheca used in our descriptions. Therefore, Grovesella has typically a schubertelloid wall, but it is not the case of the group initially named Schubertella mosquensis. All the authors admitted that this latter form is transitional between the Ozawainelloidea Profusulinellidae (with the dark microgranular wall of this group) and the Schubertellidae (with their typical shape, coiling, deviated juvenarium, septal folding, etc.). It is relevant, in this case, that Grovesella contains various lineages of small, globular schubertellins and encompasses several genera or subgenera; a Pennsylvanian part of them having a microgranular wall and being derived from Schubertina/ Eoschubertella (see above), the second part, Permian in age, having a typical schubertellid wall with a primatheca (or protheca) and probably derived from typical Schubertella.

Occurrence. Bashkirian(?)-Artinskian of UralsArctic, Carnic Alps-Chios, Darvaz, Afghanistan, and Central Iran (Davydov and Arefifard, 2007; Leven and Gorgij, 2011). Murgabian-Midian of Maku (this work).

\section{Grovesella cf. tabasensis Davydov and Arefifard, 2007}

Figure 13.13-16

2007

Grovesella tabasensis Davydov and Arefifard, p. 6, fig. 4.12-16.

Description. Small, nautiloid tests, slightly umbilicate, without chomata.

Remarks. One of the reviewer of our manuscript suggested that this taxon is identical to $G$. tabasensis, but this assignment is questionable, because, if our material is poor (20 specimens), the type material of $G$. tabasensis is even poorer. Indeed, $G$. tabasensis was described with a material of 5 specimens of the Early Permian of central Iran and 20 specimens of the Early Permian of Nevada (U.SA). However, some years later, Davydov (2011) created, with all the material of Nevada, the species G. nevadaensis Davydov, 2011. Consequently, the type material of $G$. tabasensis was reduced to five specimens. Therefore, (1) an accurate comparison is difficult, and (2) it is surprising that a genus of fusulinids was founded, in the 21th century, with a type species represented by only five specimens.

Occurrence. Murgabian-Midian of Maku (P2, P3, P7, P10, P20, P21, P30 and P34).

\section{Genus GROVESELLA?}

Comparison. Grovesella? differs from Grovesella by the smaller size, the discoidal test, the coiling more endothyroid than schubertelloid (in particular, the obvious absence of tight and deviated first whorls). It differs from Endothyra and Planoendothyra by the type of wall, which is typically schubertellid. It differs from all other schubertelloids by its character very primitive, and it is probably homeomorphous of the Bashkirian forms transitional from the pseudostaffelloids and the schubertelloids. Similarly, Grovesella? might constitute a parallel homeomorphous lineage with the Grovesella and Schubertella forms found in our material (see below).

Occurrence. As for Grovesella? ciryi n. sp.; i.e., Murgabian-early Midian of Maku

Grovesella? ciryi Ebrahim Nejad and Vachard n. sp.

Figure 13.9-12

zoobank.org/74752719-6E0E-4893-A8F1-BD1CC94258F3

Etymology. To the great specialist of fusulinids Raymond Ciry who created notably the genus Dunbarula.

Holotype. Figure 13.10 (P10).

Type locality. Maku (Northwest Iran).

Type level. Murgabian.

Diagnosis. An atypical Grovesella characterized by its "endothyrid" shape and type of coiling.

Description. Test subdiscoidal, compressed, with rounded periphery. Proloculus small, spherical. No juvenarium. Septa plane; only weakly curved at the poles. Deviation of axis permanent but slight (i.e., endothyroid in coiling). Chomata absent or very weak (Figure 11.9). Aperture basal in arch. Diameter $=0.150-0.220($ rarely $0.500 \mathrm{~mm}) \mathrm{mm}$; width $=$ $0.090-0.100 \mathrm{~mm}$ (rarely $0.300 \mathrm{~mm}$ ); $w / D=0.46$ 0.60 ; proloculus diameter $=0.020-0.035 \mathrm{~mm}$; number of whorls: $3-4$; number of chambers: $8-11$; height of last chamber: $0.030-0.050 \mathrm{~mm}$ (rarely $0.075 \mathrm{~mm}$ ); wall thickness at the last whorl: $0.005-$ $0.010 \mathrm{~mm}$ (rarely $0.015 \mathrm{~mm}$ ).

Material. 15 sections.

Repository of the material. University of Lille1, number USTL 100-3.

Comparison. In addition to the characters which differ from the typical genus, $G$.? cyrii n. sp. differs from the other Iranian species G. tabasensis by 
form ratio (w/D) of $0.46-0.60$, when the typical $G$. tabasensis have a w/D parameter of 0.60-0.85.

Occurrence. Murgabian-early Midian of Maku (P10, P17, P22 and P34).

\section{Genus DUNBARULA Ciry, 1948}

Type species. Dunbarula matthieui Ciry, 1948.

Description. Schubertelloid (i.e., having a wall with tectum and protheca) with a moderately sized, inflated fusiform test. First two to five volutions forming a juvenarium perpendicular to the two to three adult wide whorls, up to $3 \mathrm{~mm}$ in length, planispirally coiled throughout, about six or seven whorls, septa strongly folded at the poles, moderately to strongly fluted in the median portion of chambers; chomata low to high, narrow, and asymmetrical, aperture terminal central and septal pores.

Occurrence. Midian of Tunisia, Croatia, Slovenia, Italy (Istria, Monte Facito, Sicily), Greece (Chios), Cambodgia, Sumatra, Thailand, Malaysia, South China, North China, Tibet, Japan, New Zealand, Koryak Terrane, Pamir, Afghanistan, Oman, Armenia, Crimea, Northern Caucasus, Turkey, Iran (Abadeh and Kuh-e Shotor: Kahler and Kahler, 1979; central Alborz: Partoazar, pl. 1(3), fig. 13 (as Codonofusiella sp.); DjuIfa area: Shabanian et al., 2007; Zagros: Insalaco et al., 2006). Questionable in North America: Washington, Oregon, Texas (USA), British Columbia (Canada).

Remarks. We agree with Leven (e.g., Leven, 1998) for considering that the FAD of the genera Sumatrina, Dunbarula and Kahlerina is located at the the base of the Midian stage. This conclusion is discussed because for example Altiner and ÖzkanAltiner (2010; text-fig. 1) indicate that Dunbarula and Kahlerina exist before the FAD of Yabeina, theoretical unique unquestionable marker of the Midian. Kobayashi and Altiner (2011) have recently described a Dunbarula protomatthieui. This species is supposed early Murgabian in age, because it is associated with Praesumatrina. Nevertheless, this Dunbarula is yet an advanced form of the genus (especially if compared with the taxon described hereafter), very similar to Dunbarula tumida Skinner, 1969 (also described in Turkey), and is associated with Aulacophloia Gaillot and Vachard, 2007 (PI. 1, fig. 22) and Glomomidiella Vachard, Rettori, Angiolini and Checconi, 2004 (PI. 2, figs. 44-51), which are both Midian-Lopingian in age. Therefore, it is probable that this assemblage and this species of Dunbarula are Midian in age. Furthermore, the type material of the type species D. matthieui, from Jebel Tebaga (Tunisia) was probably defined in early Djulfian beds of this locality (study in progress with W. Ghizzay and S. Razgallah). Concerning the specimens of Praesumatrina associated with Dunbarula, there are at least three solutions: (a) a Lazarus effect in this single locality; (b) more likely, we have observed in a thin section from Afghanistan of the collection D. Vachard (University Lille 1), that an atypical Sumatrina specimen is devoid of transverse septula of second order; (c) moreover, in the same collection, it is conspicuous that the septula of the genera Afghanella and Sumatrina, are often rudimentary or even absent, and do not permit to assign many specimens to one or another genus. This problem might also exist in Turkey and is most probably ontogenetic than biostratigraphic.

Dunbarula aff. pusilla Skinner, 1969

Figure 13.23

1969 Dunbarula pusilla Skinner, p. 7-9, pl. 11, figs. 4-9, pl. 12, figs. 1-4.

?1983b ?Dunbarula sp.; Jenny-Deshusses, pl. 9, fig. 8.

Description. This species is very primitive and seems exactly transitional with Neofusulinella Deprat, 1912 (e.g., with N. aff. kobrigensis sensu Davydov et al., 1996), but it belongs yet to Dunbarula by the septal folding relatively intense at the poles and the deviation of juvenarium. Our material is relatively similar to $D$. pusilla, from the Midian of Turkey, but this one shows a stronger septal folding. True $D$. pusilla seem exist in Iran (Abadeh) under the name $D$. cf. matthieui sensu Kobayashi and Ishii (2003, p. 313, pl. 1, figs. 27-28).

Remark. The Dunbarula? of Jenny Deshusses (1983b) belongs eventually to this taxon or more probably are congeneric with the Alborz Neofusulinella illustrated by Bozorgnia (1973).

Occurrence. Early Midian of Maku (P30).

Superfamily SCHWAGERINOIDEA Dunbar and Henbest, 1930 nom. translat. Solovieva, 1978

Family CHUSENELLIDAE Kahler and Kahler, 1966 Genus CHUSENELLA Hsu, 1942

Type species. Chusenella ishanensis Hsu, 1942. Description. Test ovate, robust fusiform to elongate fusiform with sharp apices, up to $13.5 \mathrm{~mm}$ in length, small to medium-sized proloculus, early whorls tightly coiled, up to eight or nine volutions in the adult, later ones more loosely expanded, early septa without fluting, later septa highly and tightly fluted throughout length; wall thin, with tectum and weakly fibrous keriotheca increasing slowly in thickness, rudimentary chomata in the juvenile stage of some species, or chomata may be com- 
pletely lacking throughout, axial filling prominent, but tunnel present in the equatorial region.

Occurrence. Middle Permian: China, Laos, Croatia, Turkey, Iran, Tunisia, Pamir, Caucasus, Japan, and USA (California, Texas, Washington).

\section{Chusenella spp.}

Figures 13.24, 14.1-14.2, 14.6, 14.8

Description. Our specimens are relatively rare, and always cut in section subaxial to tangential sections. The most identifiable specimen (Figure 14. 1) seems to be relatively similar to Chusenella conicocylindrica Chen, 1956; especially, to the specimens attributed to this species by Leven (1998, pl. 6, figs. 11, 15, 19); Kobayashi and Ishii (2003, pl. 9, figs. 1-2); and Kobayashi (2011a, figs. 2.7-8). It seems also rather identical to Schwagerina sp. of Partoazar (1995, pl. 1(1), fig. 4). This test, relatively large, is inflated in the centre and conical at the poles; its keriotheca is well developed and resembles a stalactotheca; and its axial filling is heavy in the central areas.

Occurrence. Late Kubergandian-early Murgabian of Armenia. Midian of South China, Turkey, Japan, Greece (Hydra), Uzbekistan (Darvaz), and Iran (Abadeh). Midian of Maku (P34, P40 and P41).

Superfamily NEOSCHWAGERINOIDEA Dunbar and Condra, 1927 orth. mut. Minato and Honjo, 1966

Family NEOSCHWAGERINIDAE Dunbar and
Condra, 1927
Subfamily NEOSCHWAGERININAE Dunbar and
Condra, 1927

Genus NEOSCHWAGERINA Yabe, 1903

Type species. Schwagerina craticulifera Schwager, 1883.

Description. The genus Neoschwagerina has a medium to large and fusiform shell, with bluntly pointed to narrowly rounded poles. The spirotheca is composed of a tectum and a fine keriotheca. The septulum occurs in two directions, i.e., in the direction of the axis of coiling (axial septula) and in the direction of coiling (transverse or spiral septula). Primary transverse septula are contact with the parachomata only adjacent to the septa in primitive forms, but extend to the top of the parachomata in advanced forms. Secondary transverse septula are generally absent. Parachomata are broad and short in the primitive species and become relatively narrower and higher in the more-evolved species. There are foramina throughout the shell.

Occurrence. The range-zone is Murgabian-Midian in age; i.e., middle-late Middle Permian; the genus is relatively common in Palaeo-Tethys, Neo-Tethys and Panthalassa, but very rare in the USA.

Neoschwagerina simplex Ozawa, 1927 emend. Sheng, 1963

1927 Neoschwagerina simplex Ozawa, p. 153-154, pl. 34, figs. 7-11, 22-23, pl. 37, figs. $3,6 a$.

1963 Neoschwagerina simplex Ozawa; Sheng, p. 234-235, pl. 34, figs. 14-15.

1967 Neoschwagerina simplex Ozawa; Leven, p. 189-190, pl. 32, figs. 8-10.

1983b Neoschwagerina schuberti Kochansky-Devidé; Jenny-Deshusses, pl. 15, figs. 1, 5 .

1988 Neoschwagerina simplex Ozawa; Kobayashi, p. 11, pl. 6, figs. 11-17, pl. 13, figs. 6-7.

1993 Neoschwagerina ex gr. simplex Ozawa; Baghbani, pl. 2, figs. 10-14.

v. 2000 Neoschwagerina simplex Ozawa; Hauser et al., fig. 4.5.

2011b Neoschwagerina simplex Ozawa; Kobayashi, p. 524, 526, pl. 32, figs. 1 20 , pl. 37, figs. 1-3 (with synonymy).

Description. Most primitive species of the genus (see the emended diagnosis of Sheng, 1963) showing moderately large, ellipsoidal to inflated fusiform tests with broadly rounded poles.

Occurrence. Early Murgabian of Palaeo- and NeoTethys (Japan, Crimea, South China, North-Pamir, SE Pamir, Vietnam, Thailand, Central Mountains of Afghanistan, Iran (Kuh-e Jamal), Sumatra, Malaysia, NW Turkey, Oman). Early Murgabian of Maku (P3, P7 and P21).

\section{Genus SUMATRINA Volz, 1904}

Type species. Sumatrina annae Volz, 1904.

Description. Test of medium size, elongate fusiform to subcylindrical, large proloculus and few loosely coiled whorls, septa long, thin, and widely spaced, thin and short primary transverse septula, 2-4 thin secondary transverse septula between adjacent primary transverse septula, their lower part thickened and clavate, may have up to seven axial septula between adjacent septa; wall very thin, of tectum and extremely thin keriotheca, parachomata massive and high, attaching to the lower ends of the primary transverse septula, axial fillings present in all but part of the last whorl; numerous foramina occur throughout the length of the test. 


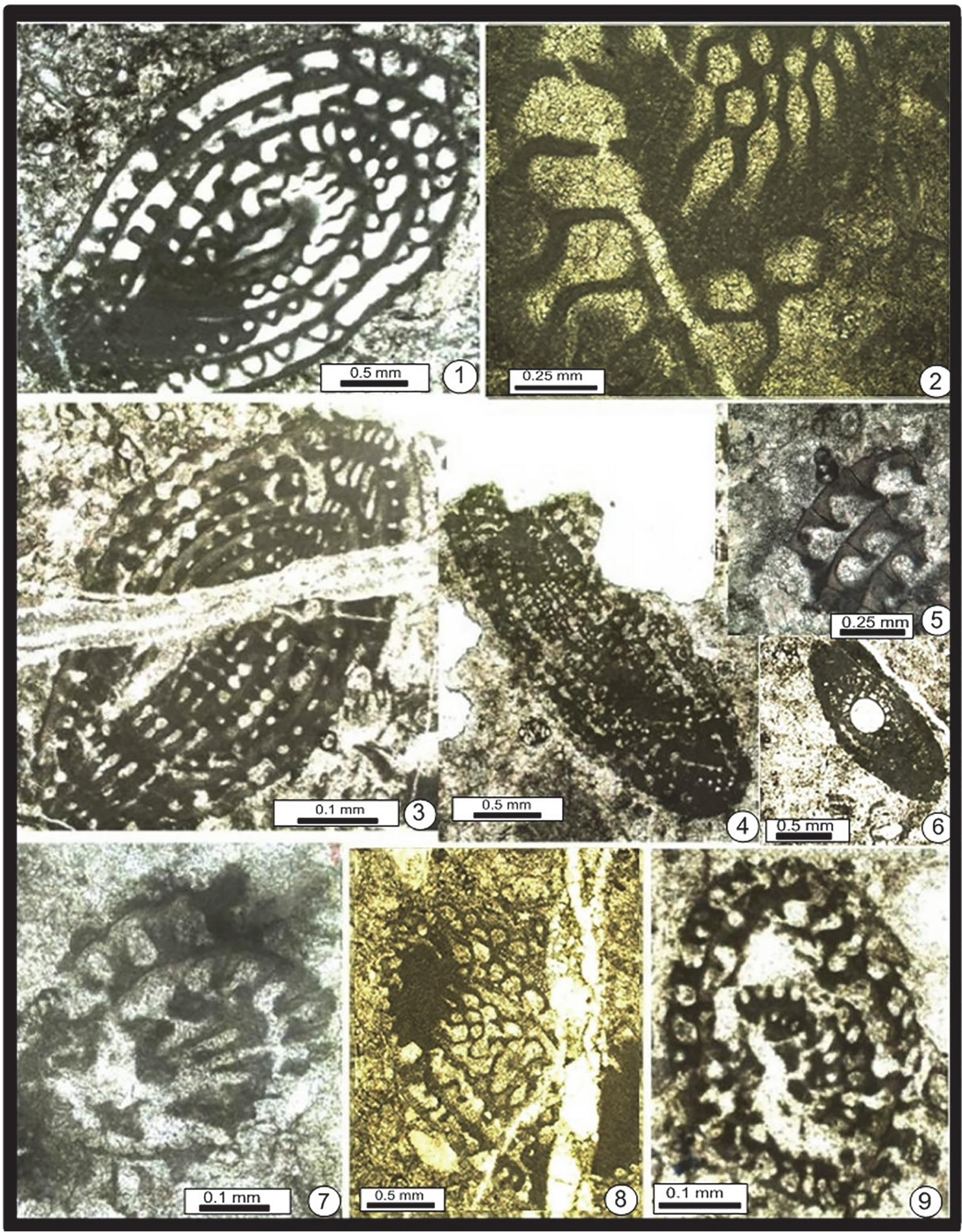

FIGURE 14. 1-2, 6, 8. Chusenella spp. 1. Subaxial section. P34-22. Midian. 2. Detail of the keriotheca. P41-25. Latest Midian. 6. Oblique section with the axial filling. P40-1. Latest Midian. 8. Oblique section with septal folding and axial filling. P40-60. Latest Midian. 3, 5, 7, 9. Neoschwagerina simplex Ozawa, 1927 emend. Sheng, 1963. 3. Subaxial section showing the parachomata and the transverse septula of first order. P21-51. Murgabian. 5. Fragment of transverse section showing the wall microstructure and the absence or rarity of axial septula. P3. Murgabian. 7. Oblique section. P3-13. Murgabian. 9. Oblique transverse section. P3-35. Murgabian. 4, 6. Sumatrina annae Volz, 1904.4. Subaxial section. P30-56. Earliest Midian. 6. Axial section of a young specimen. P30-54. Earliest Midian. 
Occurrence. Late Middle Permian (Midian); Sumatra, South China (Yunnan, Kueichow, Kwangsi), ?Tibet, Primorye, Laos, Cambodgia, Vietnam, Thailand, Malaysia, S.E. Pamir, Afghanistan, Japan, Iran (Espahan, Abadeh), Armenia, Turkey, Crimea, Greece, Croatia, Tunisia.

\section{Sumatrina annae Volz, 1904}

Figure 12.4-12.5

1904 Sumatrina annae Volz, p. 98-100, text figs. 27-31.

1963 Sumatrina annae Volz; Sheng, p. 245246, pl. 36, figs. 1-11.

1967 Sumatrina annae annae Volz; Leven, p. 200, pl. 37, figs. 6-7, 9.

1967 Sumatrina annae brevis Volz; Leven, p. 201, pl. 37, figs. 4-5.

? 1998 Sumatrina vediensis Leven, p. 325, pl. 9, figs. 18-20.

2003a Sumatrina annae Volz; Kobayashi and Ishii, fig. 5.7-8.

2003b Sumatrina annae Volz; Kobayashi and Ishii, p. 328, pl. 11, figs. 7-14.

2011 Sumatrina annae Volz; Leven and Gorgij, pl. 28, fig. 16.

Description. Test of medium size for the genus, elongate fusiform, with 9-10 whorls and a length of $5.600-6.500 \mathrm{~mm}$. Two to three transverse septula of second order are located between each transverse septulum of first order.

Remarks. The specific differences of $S$. annae, $S$. brevis and $S$. vediensis are not very easy to characterize, a synonymy is possible.

Occurrence. Midian of Sumatra, South China (Yunnan, Kueichow, Kwangsi), Tibet?, Laos, Viet nam, Thailand, Malaysia, S.E. Pamir, Afghanistan, Primorye, Japan, Turkey, Crimea, Italy, Croatia, Tunisia, Armenia and Iran (Espahan, Abadeh). Maku (P30).

\section{Class MILIOLATA Lankester, 1885}

Order MILIOLIDA Delage and Hérouard, 1896

Superfamily NUBECULARIOIDEA Jones in Griffith and Henfrey, 1875 nom. translat. Mikhalevich, 1988

Family CALCIVERTELLIDAE Loeblich and

Tappan, 1964 nom. translat. Reitlinger in Vdovenko et al., 1993 emend. Gaillot and Vachard, 2007

Genus PSEUDOVERMIPORELLA Elliott, 1958 emend. Henbest, 1963

Type species. Pseudovermiporella sodalica Elliott, 1958.
Remarks. Although the work of Henbest (1963) had definitively demonstrated that Pseudovermiporella is a miliolid foraminifer, this genus has been still recently considered as an alga (Granier and Deloffre, 1994; Gaetani et al., 2009; Angiolini et al., 2010; Schlagintweit, 2011) or a microproblematicum (Flügel, 2004). The type of development and the amber-coloured, well- preserved test are characteristic of a porcelaneous foraminifer. That is only after a microsparitic recrystallisation and an inner abrasion of the tube, that this porcelaneous can be confused with a dasyclad. Unlike Palaeonubecularial"Tolypammina", from Moscovian (Delvolvé et al., 1987, pl. 1, fig. 11) to Triassic time (Wendt, 1969), microreefs with Pseudovermiporella are lacking in the Earth history, probably due to the biological function of the pits, which cannot be covered. Our new material definitively confirms the existence of proloculi and juvenaria.

Although some questionable species, like Pseudovermiporella? graiferi (Baryshnikov in Baryshnikov et al., 1982 emend. Vachard and Krainer, 2001), appear in the latest Sakmarian, the FAD of true Pseudovermiporella is probably early Artinskian in age (Vachard, Krainer and Lucas, unpublished data). The main Middle-Late Permian species are $P$. nipponica (with its numerous synonyms), probably cosmopolite; $P$. sodalica, apparently limited to western Neo-Tethys; and $P$. elliotti, only known in Turkey and Oman (Vachard et al., 2001). The numerous other species described in the literature are probably all junior synonyms of these three ones.

Occurrence. Late Early Permian (Artinskian)-Late Permian (Changhsingian), cosmopolite. Common in Lopingian of southern Turkey (Hazro) and Zagros.

Pseudovermiporella nipponica (Endo in Endo and Kanuma, 1954)

Figure 15.3-15.4, 15.6, 15.8-15.10, 15.13-15.14

1954 Vermiporella (?) nipponica Endo in Endo and Kanuma, p. 191, pl. 13, figs. 2-5.

1963 Vermiporella nipponica Endo; Praturlon, p. 124-126, pl. 1, figs. 1-10 (with synonymy).

v. 1981 Pseudovermiporella ex gr. nipponica (Endo); Vachard in Vachard and Montenat, p. $72-73$, pl. 2, fig. 8 , pl. 13 , fig. 12, pl. 14, figs. 1-3.

1983b Pseudovermiporella ex gr. nipponica (Endo); Jenny-Deshusses, p. 155, pl. 


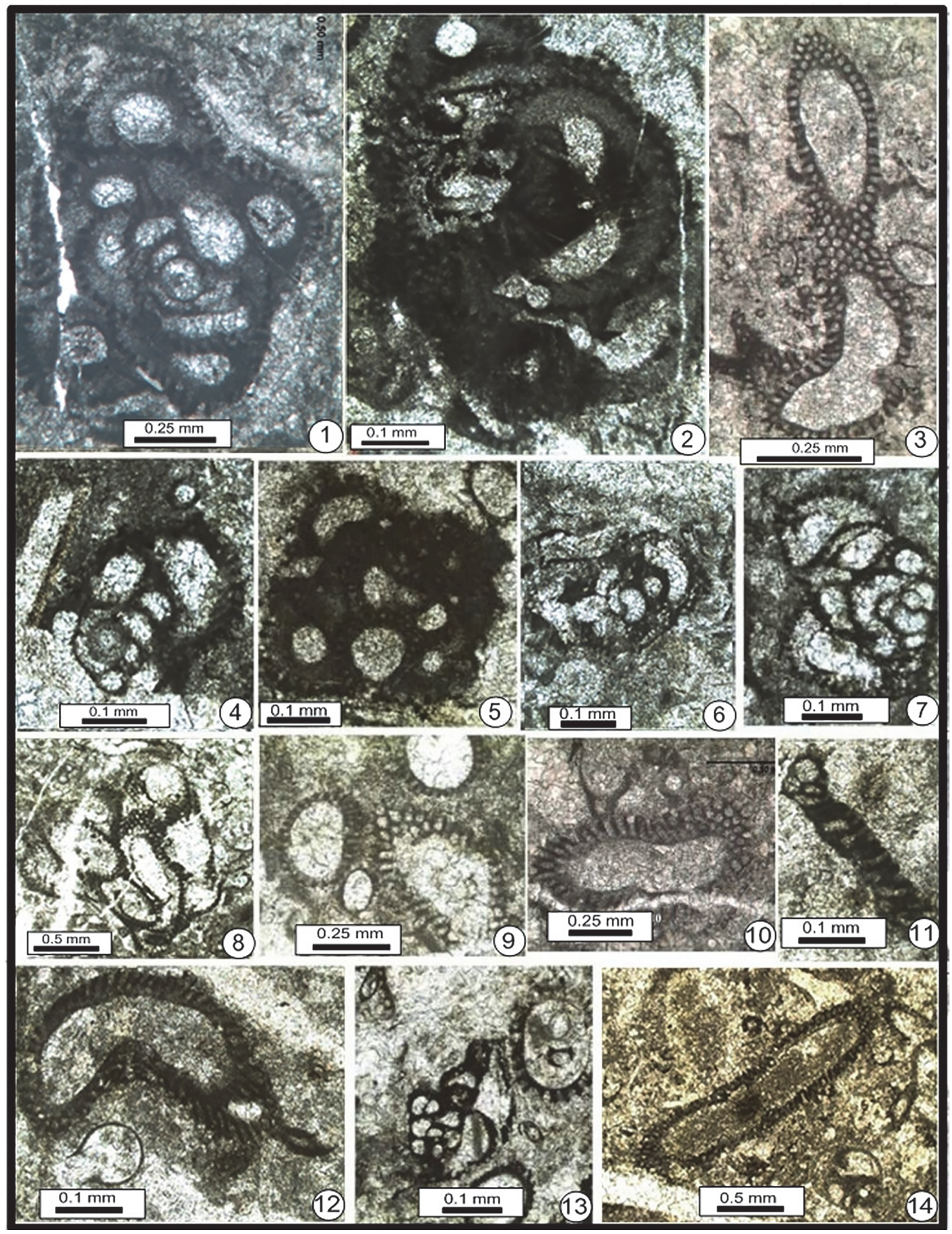

FIGURE 15. 1-2, 5, 7? Pseudovermiporella sodalica Elliott, 1958. 1. Typical specimen. P22. Murgabian. 2. Typical thick wall. P8-42. Murgabian. 7? Thick-walled specimen with the proloculus (centre, right). P27-7. Murgabian. 3-4, 6, 8-10, 13-14. Pseudovermiporella nipponica (Endo in Endo and Kanuma, 1954). 3. Longitudinal to tangential section. P22. Murgabian. 4. Juvenarium with the proloculus. P27-42. Murgabian. 8. Group of tubules. P27-37. Murgabian. 9. Two transverse sections. P16-42. Murgabian. 10. Longitudinal section. P22. Murgabian. 13. A juvenarium (centre) and various adult sections. P6. Early Murghabian. 14. Longitudinal section (centre) with Labioglobivalvulina cf. baudi (bottom right). P17-28. Murgabian. 11-12. Pseudovermiporella longipora (Praturlon, 1963). 11. Detail of the wall. P17-30. Murgabian. 12. Longitudinal section with Eotuberitina reitlingerae (Figure 8.2). P17-14. Murgabian. 
16, figs. 2, 5?, pl. 20, fig. 4 (with synonymy).

v. 1993a Pseudovermiporella ex gr. nipponica (Endo); Vachard et al., pl. 6, fig. 9, pl. 7, fig. 1.

1995 Vermiporella nipponica Endo; Partoazar, pl. 1(3), fig. 9, pl. 2(3), fig. 5, pl. $3(2)$, fig. 12, pl. 6(4), fig. 4, pl. 8(5), figs. 4, 6, 10.

v. 2001 Pseudovermiporella nipponica (Endo); Vachard and Krainer, p. 191, pl. 4, fig. 26 (with synonymy).

v. 2007 Pseudovermiporella nipponica (Endo); Gaillot and Vachard, p. 82-83, pl. 58, fig. 16 , pl. 59 , figs. 4,19 (with synonymy).

v. 2009 Pseudovermiporella ex gr. nipponica (Endo); Mohtat-Aghai et al., pl. 1, fig. 12.

2010 Mizzia velebitana Pia; Angiolini et al., fig. 4.33.

v. 2013 Pseudovermiporella nipponica (Endo); Parvizi et al., fig. 9h.

Description. Dimensions: $L=1.250-2.500 \mathrm{~mm}$; $D$ $=0.325-0.960 \mathrm{~mm} ; \mathrm{d}=0.170-0.440 \mathrm{~mm} ; \mathrm{s}=$ up to $0.260 \mathrm{~mm}$; width of pits $=0.015-0.036 \mathrm{~mm}$. Excellent examples of spherical or even reniform proloculi have been discovered in our material (Figure 15.4, 15.6).

Occurrence. As for the genus. Very common in all the series of Maku (P1, P3, P6, P7, P8, P9, P10, $\mathrm{P} 14, \mathrm{P} 16, \mathrm{P} 17, \mathrm{P} 18, \mathrm{P} 20, \mathrm{P} 21, \mathrm{P} 22, \mathrm{P} 23, \mathrm{P} 25$, P27, P30, P31, P34, P37, P39, P41, P44, P50, $\mathrm{P} 51, \mathrm{P} 54$ and P55).

Pseudovermiporella sodalica Elliott, 1958 Figure 15.1-15.2, 15.5, 15.7

1958 Pseudovermiporella sodalica Elliott, p. 419-422, pl. 1, figs. 1-6, pl. 2, figs. 2-6, pl. 3, figs. 1-4, 7 .

v. 2006 Pseudovermiporella sodalica Elliott; Insalaco et al., pl. 1, fig.12.

v. 2007 Pseudovermiporella sodalica Elliott; Gaillot and Vachard, p. 83, pl. 34, fig. 18 , pl. 57, figs. 2-6 (with synonymy).

v. 2013 Pseudovermiporella sodalica Elliott; Parvizi et al., fig. 9a-b.

Dimensions. $L=0.400-0.700 \mathrm{~mm}, D=0.400-$ $0.600 \mathrm{~mm}, \mathrm{~d}=0.500-0.600 \mathrm{~mm}, \mathrm{~s}=$ up to 0.600 $\mathrm{mm}$, width of pits $=0.020-0.040 \mathrm{~mm}$. Unquestionable proloculi and foraminiferal coiled first whorls have been observed (Figure 15.1, 15.7). The proloculi are also spherical or reniform.

Remarks. This species differs from $P$. nipponica by thicker walls, larger tubes and wider pits.

Occurrence. More endemic than $P$. nipponica. Common in Late Midian-Lopingian of Zagros, Iraq, Fars and Abu Dhabi. Murgabian in Maku (P1, P3, P5, P8 and P27).

Pseudovermiporella longipora (Praturlon, 1963)

Figure 15.11-15.12

1963 Vermiporella nipponica var. longipora Praturlon, p. 126, pl. 2, figs. 1-7.

v. 2001 Pseudovermiporella longipora (Praturlon) n. comb.; Vachard et al., p. 396, fig. 21.15-21.16.

v. 2003 Pseudovermiporella ex gr. nipponica (Endo); Vachard et al., pl. 4, fig. 3.

v. 2013 Pseudovermiporella longipora (PraturIon); Parvizi et al., fig. 9i.

Remarks. This species differs from $P$. nipponica by deeper and more curved pits.

Occurrence. Murgabian of Maku (P16 and P17).

Superfamily CORNUSPIROIDEA Schultze, 1854 nom. translat. Mikhalevich, 1988

Family CORNUSPIRIDAE Schultze, 1854

Subfamily CORNUSPIRINAE Schulze, 1854

Genus HEMIGORDIELLINA Marie in Deleau and

Marie, 1961 emend. Vachard in Vachard and Beckary, 1991

Type species. Glomospira diversa Cushman and Waters, 1930.

Synonyms. Glomospira (of the Russian authors; from Lipina, 1949 to Filimonova, 2010).

Remarks. Small glomospiroid porcelaneous tests are here assigned to Hemigordiellina, because "Glomospira" is truly agglutinated and Pseudoglomospira (of the authors) microgranular. Many micropalaeontologists do not admit this interpretation, and therefore, a new name might be introduced in the nomenclature. Among the Cornuspiridae, the most primitive, late Mississippian, streptospiral genus, Hemigordiellina, give rise, in the Pennsylvanian, to Hemigordius (the terminal stage of which is planispiral). Then, Hemigordius give rise to a Early Permian genus with an oscillating-sygmoidal terminal coiling, also called Hemigordius or Midiella in the literature. Both names are incorrect; the first one because of the different coiling, the second one because the typical Midiella appear very later in the Late Permian, coming from another lineage. 
Occurrence. Pennsylvanian-Permian; cosmopolite.

Hemigordiellina regularis (Lipina, 1949)

Figures 8.11, 9.1, 9.13, 16.2, 16.7-13, 19.28

1949 Glomospira regularis Lipina, p. 205, pl. 2, fig. 6.

p. 1981 Glomospira spp.; Okimura and Ishii, pl. 2, figs. 2?, 4 (neither fig. $3,5=$ Hemigordiellina? spp.; nor figs. 6-7 = Glomomidiella nestellorum).

v. 2005 Hemigordiellina regularis (Lipina); Vachard et al., p. 157, pl. 2.6, 2.8 (with synonymy).

v. 2006 Hemigordiellina regularis (Lipina); Insalaco et al., pl. 1, fig. 8.

v. 2007 Hemigordiellina regularis (Lipina); Gaillot and Vachard, p. 85, pl. 2, figs. $5-6,7$ ?, 8, 14, pl. 4, figs. 21-22, pl. 14, figs. 6,8 , pl. 63 , figs. $4-8$ (with synonymy).

2010 Hemigordiellina regularis (Lipina); Angiolini et al., fig. 4.14.

Dimensions. Our measurements are similar to those of the type material. $D=0.250-0.500 \mathrm{~mm} ; \mathrm{p}$ $=0.025-0.060 \mathrm{~mm} ; \mathrm{h}=0.050-0.075 \mathrm{~mm} ; \mathrm{s}=0.007-$ $0.015 \mathrm{~mm}$.

Occurrence. From Early Permian (Lipina, 1949; Lin et al., 1990) to latest Triassic (Salaj et al., 1983). Typical specimens of $H$. regularis are mostly present in the late Capitanian and abundant in the Djulfian of Persian Gulf. Very common and widespread in Maku (P1, P3, P6, P8, P9, P10, P16, $\mathrm{P} 17, \mathrm{P} 18, \mathrm{P} 19, \mathrm{P} 20, \mathrm{P} 21, \mathrm{P} 23, \mathrm{P} 30, \mathrm{P} 31, \mathrm{P} 32$, P33, P34, P35, P38, P39, P40, P41, P45 and P51).

Hemigordiellina? pulchrissima Ebrahim Nejad and Vachard $\mathrm{n}$. sp.

Figures 17.2-17.3, 17.21, 18.1

zoobank.org/20D6170D-D454-4FD2-9701-C355FB0A1FDF

p. 1981 Glomospira spp.; Okimura and Ishii, pl. 2, fig. 3 (neither figs. 2, $4-5=$ Hemigordiellina (sensu lato); nor figs. 6-7 = Glomomidiella nestellorum).

p. 1995 Kamurana jolfiensis Partoazar, pl. 2(1), fig. 13 (nomen nudum: no description, no holotype designation) (non fig. 21 = Glomomidiella cf. nestellorum).

?1997 Glomospira tenuifistula Ho; Kobayashi, pl. 3, figs. 19-20.

2007 Kamurana cf. Bronnimanni (sic); Shabanian et al., pl. 1, fig. 9.
Etymology. Latin, pulcher, pulchra, pulchrissima; i.e., a very nice small form.

Holotype. Figure 17.21 (P39).

Type locality. Maku (Northwest Iran).

Type level. Late Midian.

Diagnosis. An atypical Hemigordiellina due to the thin whorls, low tube and numerous whorls.

Description. Small ovoid test with numerous whorls. $D=0.200-0.275 \mathrm{~mm} ; \mathrm{w}=0.160-0.250 \mathrm{~mm}$. The central glomus is relatively large with numerous glomospiroid whorls, followed by oscillant whorls semi-evolute to evolute. The proloculus is small but larger than the first whorls; it measures $0.025-0.030 \mathrm{~mm}$. Up to seven initial, streptospiral whorls and two to three terminal whorls tending to be aligned. The porcelaneous wall is proportionally thin $(s=0.005-0.010 \mathrm{~mm})$. Aperture terminal, simple.

Material. 20 sections (P30 and P39).

Repository of the material. University of Lille 1 , number USTL 100-04.

Comparison. No typical Hemigordiellina can be compared with this new species; some coiling similarities exist with the Triassic genus Pilammina Pantic, 1965.

Occurrence. Iran: early Djufian of Djulfa; late Midian of Maku.

\section{Hemigordiellina? sp. 2}

Figure 16.14-17

p 1981 Glomospira spp.; Okimura and Ishii, pl. 2, fig. 5 (neither figs. 2-4 = Hemigordiellina (sensu lato); nor figs. 6-7 = Glomomidiella nestellorum).

Remarks. The material seems relatively typical of this long-ranged species or group of species (Artinskian-Dorashamian).

Occurrence. As for the genus. Murgabian-Djulfian in Maku (P3, P20, P30, P32, P34, P39, P40, P45, P51, P52, P54 and P55).

\section{Hemigordiellina? sp. 3}

Figure 15.1

1981

Glomospirella? sp.; Okimura and Ishii, pl. 2, fig. 23.

Remark. Our material is poor; the initial coiling is unconspicuous; the terminal whorls seem evolute; some pseudosepta seem present; and the wall is very thin for the genus. This taxon is also relatively similar to Pseudoagathammina Lin, Li and Sun, 1990, non sensu Filimonova, 2010.

Occurrence. Murgabian-Midian of Maku (P 10, P31, P39?).

Subfamily AGATHAMMININAE Ciarapica, Cirilli and Zaninetti in Ciarapica et al., 1987 


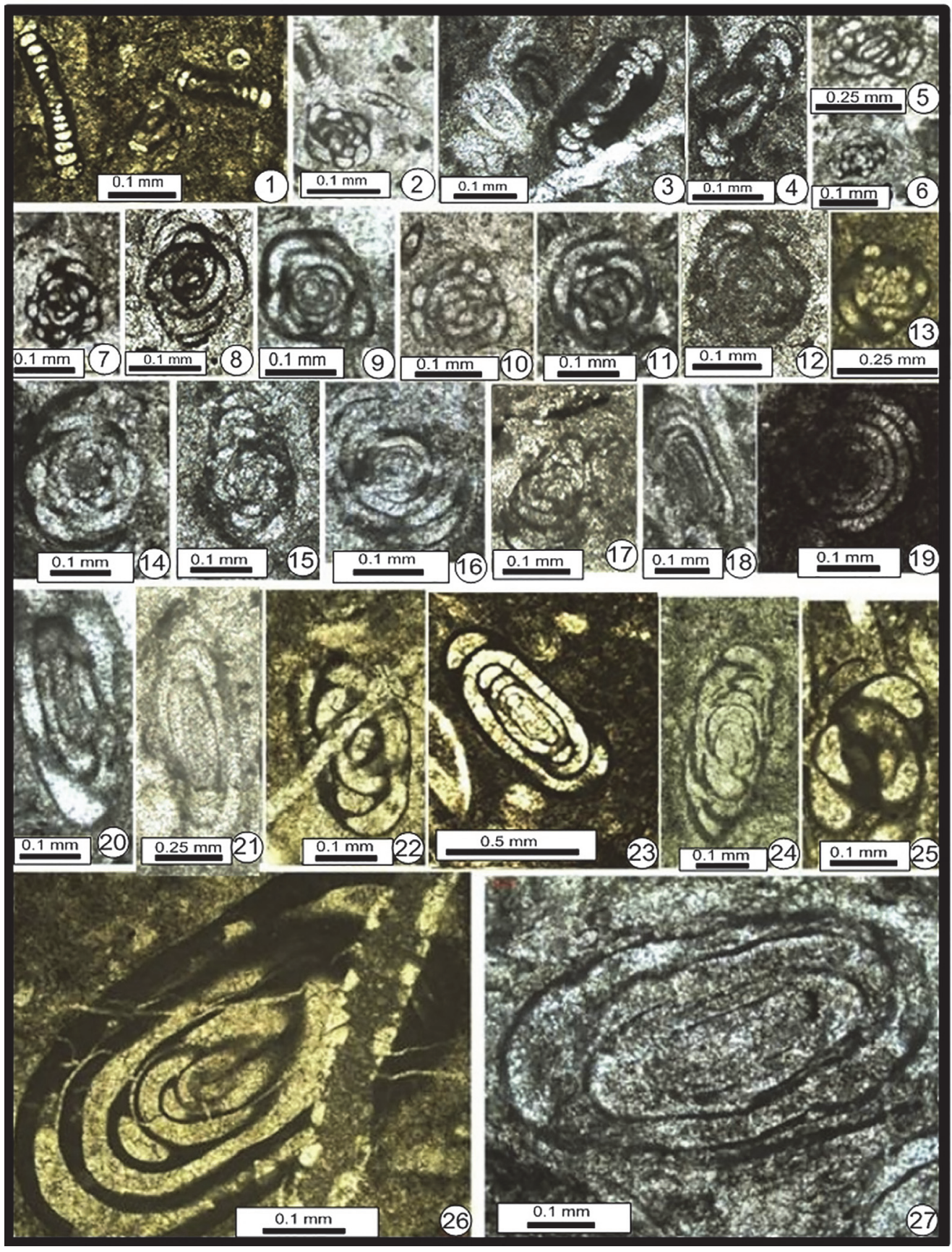

FIGURE 16. 1-2, 3?, 4?, 5?, 6?, 19? Okimuraites plana (Okimura and Ishii, 1981). 1 Two typical specimens (left and right) with Hemigordiellina? sp. (centre). P39-50. Midian. 2. Two axial sections (top) with Hemigordiellina regularis (bottom). P31-12. Murgabian. 3? Subaxial section (right) with Syzrania n. sp.? (left). P32-7. Midian. 4? Subaxial section. P32-22. Midian. 5? Subaxial section. P30-4. Midian. 6? Axial section. P18-13. Murgabian. 19? Transverse section. P27-18. Murgabian. 7-13. Hemigordiellina regularis (Lipina, 1949). Seven random sections. 7. P6-23. Murgabian. 8. P6-11. Murgabian. 9. P8-44. Murgabian. 10. P10-3. Murgabian. 11. P21-35. Murgabian. 12. P22-7. Murgabian. 13. P41-26. Midian. 14-17. Hemigordiellina? sp. 2. 14. Oblique section. P34-7. Midian. 15. Axial section. P32-33. Midian. 16. Oblique section. P32-33. Midian. 17. Subaxial section. P10-31. Murgabian. 18. Agathammina parvula (Lin, 1978). Three longitudinal sections. 18. P21-36. Murgabian. 20-21. Agathammina cf. rosella Pronina, 1988b. 20. P8-47. Murgabian. 21. P27-3. Murgabian. 22-25. Agathammina cf. subfusiformis Okimura and Ishii, 1981. Four subaxial sections. 22. P41-74. Latest Midian. 23. P41-8. Latest Midian. 24. P38-7. Midian. 25. P39-36. Midian. 26-27. Agathammina pusilla (Geinitz in Geinitz and Gutbier, 1848) emend. Wolanska, 1959. Two axial sections. 26. P41-47. Midian. 27. P34-33. Midian. 
Genus AGATHAMMINA Neumayr, 1887 emend. Wolanska, 1959

Type species. Serpula pusilla Geinitz in Geinitz and Gutbier, 1848.

Description. Test elongate. Chamber undivided, tubular with a quinqueloculine coiling. Wall porcelaneous. Aperture terminal, simple.

Remark. This genus constitutes the link between the Palaeozoic primitive Miliolata and the true Milolata. It is very easy to identify in thin sections; not only in axial sections but also in transverse sections.

Occurrence. FAD poorly known probably Artinskian (= Yakhtashian) of Darvas (Tajikistan), with A. darvasica Filimonova, 2010. The LAD occurs during the latest Permian; hence, the Triassic "Agathammina" belong to another genus. Essentially Palaeo- and Neo-Tethyan, the genus Agathammina is nevertheless present in the USA (New Mexico; Nestell and Nestell, 2006).

Agathammina parvula (Lin, 1978)

Figure 14.18

1978 Hemigordius parvulus Lin, p. 39, pl. 5, figs. 18-19.

v. 2007 Agathammina ovata Wang; Gaillot and Vachard, p. 88, pl. 22, fig. 7, pl. 55, fig. 6, pl. 67, fig. 6 .

2010 Agathammina ex gr. multa Pronina; Filimonova, pl. 2, fig. 17.

Remarks. This species is identical to $A$. pusilla but smaller for the same number of whorls. It differs from $A$. ovata Wang, 1976 by a smaller size; moreover, $A$. ovata is possibly a juvenarium of $A$. pusilla.

Occurrence. Middle Permian of South China and NW Caucasus. Late Midian-Changhsingian of Zagros. Kungurian (= Bolorian) of Armenia. Murgabian-Midian of Maku (P3, P7, P37 and P41).

Agathammina cf. rosella Pronina, 1988b Figure 16.20-21

1988b Agathammina rosella Pronina, p. 6162, fig. 3.11.

v 2007 Agathammina cf. rosella Pronina; Gaillot and Vachard, p. 88, pl. 67, fig. 1.

Description. Test ovoid elongate, medium-sized for the genus, thin-walled.

Occurrence. Murgabian-Midian of Maku (P1, P3, P6, P21, P23, P31, P32, P34 and P39).
Agathammina cf. subfusiformis Okimura and Ishii, 1981

Figures 16.22-25, 17.5

1981

Agathammina subfusiformis Okimura and Ishii, p. 16, pl. 1, figs. 7-8.

1995 Agathammina subfusiformis Okimura and Ishii; Partoazar, pl. 2(1), fig. 6, pl. 3(1), fig. 2 pl. 2(2), fig. 1.

Description. Test ellipsoidal, medium-sized and thick-walled.

Occurrence. Murgabian-Midian of Maku (P8, P10, P11, P20, P27, P30, P31, P34, P37, P38, P39 and P41).

Agathammina pusilla (Geinitz in Geinitz and Gutbier, 1848) emend. Wolanska, 1959

Figure 16.26-27

1848 Agathammina pusilla Geinitz in Geinitz and Gutbier, p. 6, pl. 3, figs. 3-6.

1959 Agathammina pusilla Geinitz; Wolanska, p. 47-48 (in Polish), 57 (in English), text-fig. 1-2 (p. 37), 3 (p. 41), 4 (p. 42), pl. 1, figs. 1a-3d, pl. 2, figs. A-C, 1-23, pl. 3, figs. 24-55 (with synonymy).

1988a Agathammina pusilla (Geinitz); Pronina, pl. 1, figs. 25-26.

1995 gathammina pusilla (Geinitz); Partoazar, pl. 2, fig. 15.

2006 Agathammina pusilla (Geinitz); Nestell and Nestell, p. 10, pl. 3, figs. 1-5 (with synonymy).

v. 2007 Agathammina pusilla (Geinitz); Gaillot and Vachard, p. 87-88, pl. 2, fig. 18, pl. 53, fig. 11, pl. 66, fig. 14.

2010 Agathammina aff. pusilla (Geinitz); Angiolini et al., fig. 4.13.

? 2011 "Agathammina"; Song et al., fig. 6.52.

Remarks. This species is large and elongate. Contrary to its name (pusillus means very small in Latin), A. pusilla is a large species. Other large or very large species have been described in the literature: A. magna sensu Ueno, 1992; A. psebaensis Pronina-Nestell and Nestell, 2001; A. gigantea Kobayashi, 2012. All are probably synonymous of A. pusilla. $\mathrm{D}=$ up to $0.900 \mathrm{~mm} ; \mathrm{w}=$ up to 0.350 $\mathrm{mm}$; $\mathrm{n}$ : up to $11-12$.

Occurrence. See the distribution indicated by Nestell and Nestell (2006) and add: Midian of Turkey; Changhsingian of South China and Primorye; Wuchiapingian of Iranian Djulfa; late Wuchiapingian to Changhsingian of Zagros. Form com- 


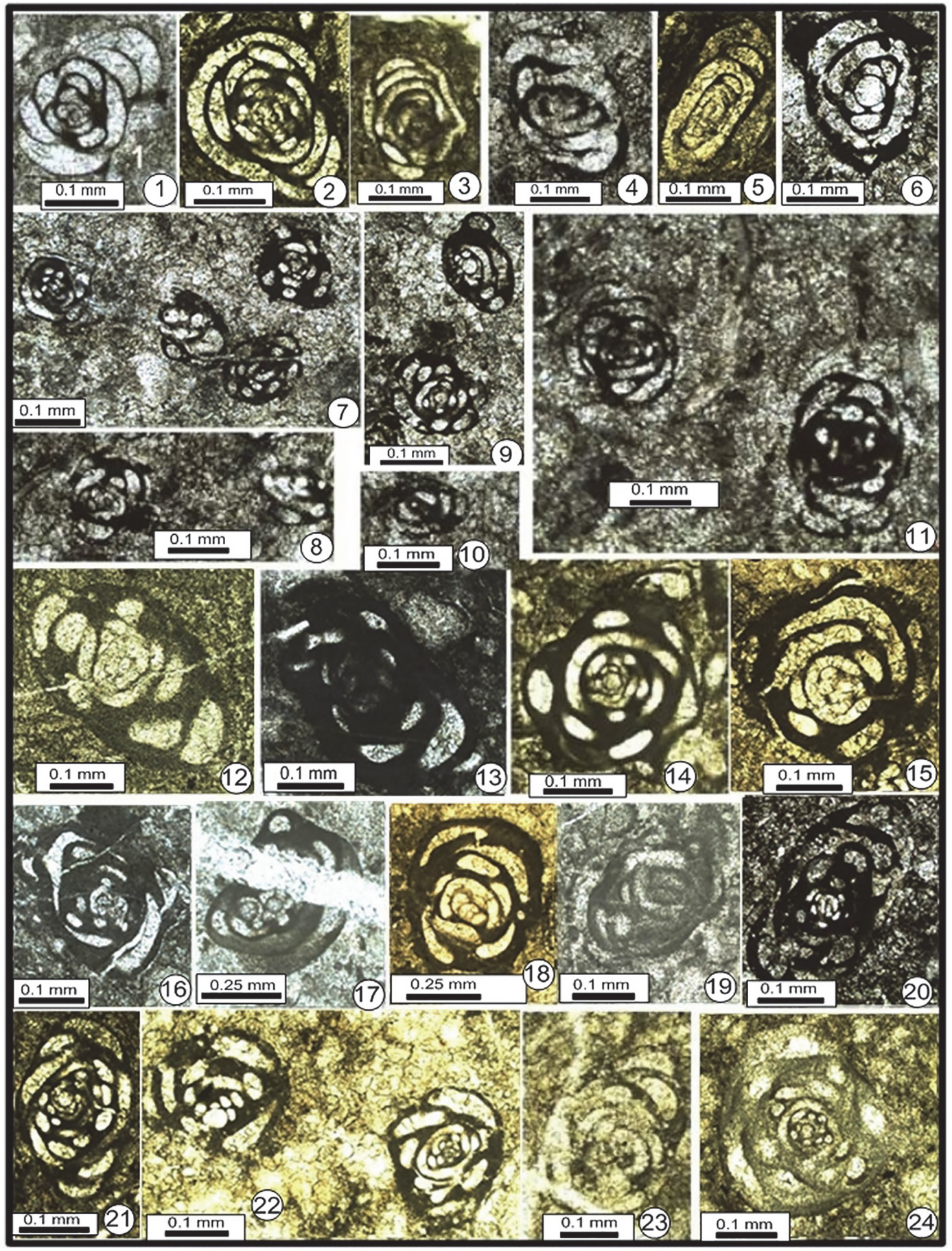

FIGURE 17. 1. Hemigordiellina? sp. 3. Axial section. P31-17. Midian. 2-3, 21. Hemigordiellina? pulchrissima Ebrahim Nejad and Vachard n. sp. Three axial sections. Midian. 2. Paratype. P39-23. 3. Paratype. P39-57. 21. Holotype. P39-45. 4, 6?, 7-11, 20? Glomomidiella nestellorum Vachard, Rettori, Angiolini and Checconi, 2008. 4. Axial section transitional to Neodiscus. P30-19. Midian. 6. Transverse section showing the pseudosepta. P30-20. Earliest Midian. 7-11. Various sections (7. P30-11; 8. P30-3; 9. P30-13; 10. P30-3; 11. P30-5). 20. P30-10. Midian. 16-17. Glomomidiella cf. gigantea (Lin, 1984). 16. P37-25. Murgabian. 17. P31-14. Midian. 5. Agathammina cf. subfusiformis Okimura and Ishii, 1981. Longitudinal section. P39-53. Midian. 12-13, 19. Neodiscus milliloides MiklukhoMaklay, 1953. Four axial sections. 12. P38-24. Midian. 13. P37-13. Midian. 19. P21-9. Murgabian. 14-15, 18. Glomomidiella? cf. specialisaeformis (Lin, Li and Sun, 1990). 14. P39-38. Midian. 15. P47-24. Djulfian.18. P47. Djulfian. 22. P47-12. Djulfian. 22-24. Glomomidiella cf. problema (Lin, 1978). 22. Two specimens. P47-24. 23. P40-13. Late Midian. 24. P44-20. Djulfian. 
mon in Maku (P32, P34, P37, P38, P39, P41 and P47).
Family HEMIGORDIIDAE Reitlinger in Vdovenko et al., 1993
Subfamily HEMIGORDIINAE Reitlinger in Vdovenko et al., 1993
Genus OKIMURAITES Reitlinger in Vdovenko et al., 1993 emend. herein

Type species. Discospirella plana Okimura and Ishii, 1981.

Synonym. Discospirella Okimura and Ishii, 1981 (preoccupied); Brunsispirella Gaillot and Vachard, 2007.

Emended diagnosis. Hemigordiinae small, discoid and with numerous planispirally coiled whorls, involute to semi-evolute and evolute.

Remarks. We consider here Okimuraites as a genus, and not as a subgenus of Hemigordius, because its more numerous for a smaller size, its more compressed and discoidal test, its stratigraphic range limited to the Midian and Late Permian, and its geographic distribution restricted to the Tethys. Our typical section of Figure 16.1-2 (left) can be compared with the associated, typical Hemigordius sp. (Figure 16.2 (right), 16.3-6) because of its more numerous whorls for a smaller size.

With the proposed emended diagnosis, Brunsispirella becomes a junior synonym of Okimuraites.

Occurrence. Midian-Lopingian of Palaeo-Tethys and Neo-Tethys.

Okimuraites plana (Okimura and Ishii, 1981)

Figures 8.7, 16.1-16.2 (top right and top left), 16.3?-16.6, 16.19?, 18.1

1981 Discospirella plana Okimura and Ishii, p. 13, pl. 1, figs.1-2.

1993 Hemigordius (Okimuraites) plana (Okimura and Ishii); Reitlinger in Vdovenko et al., p. 89, pl. 14, figs. 1819.

v. 2005 Glomospirella? linae Vachard and Gaillot in Vachard et al., p. 157, 159, pl. 4.3-4.17.

v. 2007 Brunsispirella linae (Vachard and Gaillot in Vachard et al.); Gaillot and Vachard, p. $98-99$, pl. 2, figs. 28, 29?, $30-31$, pl. 56 , figs. $1-2,4-7,12$, pl. 60 , fig. 1 , pl. 68 , figs. $6,9-10,13,15-17$, 20 (with synonymy).

2009 Hemigordius longus Grozdilova; Song et al., fig. 7.3-6.
2009

v. 2009

Hemigordius discoides $\mathrm{Lin}, \mathrm{Li}$ and Sun; Ueno and Tsutsumi, fig. 9.17.

Brunsispirella aff. linae (Vachard and Gaillot in Vachard et al.); Mohtat-Aghai et al., pl. 2, fig. 3.

Description. This Miliolata (i.e., with a porcelaneous wall) is a homeomorph of Brunsia spirillinoides (Grozdilova and Glebovskaya, 1948). It summarizes all the nomenclatural problems of Miliolata Cornuspiroidea and Fusulinata Pseudoammodiscoidea; and how two primitive taxa can appear similar, although they belong to two different classes. Like for Brunsia, in the abundant populations, some oblique, juvenile and transverse sections (Figure 16.3-6, 16.19) can be confused with other primitive undivided, bilocular genera.

Occurrence. Murgabian-Dorashamian of PalaeoTethys and Neo-Tethys. Murgabian-Midian (P6, P20, P21, P27, P30, P31, P32, P39 and P45).

Family NEODISCIDAE Lin, 1984 nom. translat. emend. Gaillot and Vachard, 2007

Description. Large Miliolata test composed of a spherical proloculus followed by an undivided tubular chamber, diversely coiled: entirely glomospiral (Crassiglomella Gaillot and Vachard, 2007), entirely glomospiral with pseudo-septa (Glomomidiella Vachard, Rettori, Angiolini and Checconi, 2008), initially glomospiral and then planispiral (or aligned) involute (Neodiscus Miklukho-Maklay, 1953), glomospiral becoming planispiral evolute or semi-involute (Graecodiscus Vachard in Vachard et al., 1993), planispirally involute compressed (Uralogordius Gaillot and Vachard, 2007 = Arenovidalina Baryshnikov, Zolotova and Kosheleva, 1982 non Ho, 1959; including Hemigordius magnus Rauzer-Chernousova in Akopian, 1974 and Neodiscus mirabilis Ueno, 1992) or inflated (Multidiscus Miklukho-Maklay, 1953), if slightly deviated at the beginning: Neohemigordius Wang and Sun, 1973), agathamminoid, i.e., pseudo-quinqueloculine (Septagathammina Lin, 1984). The chamber is semicircular in section (some flosculinisations are observable in advanced forms of Neodiscopsis Gaillot and Vachard, 2007), the thick wall is still re-inforced by buttresses at the contact with the preceding whorl. Aperture terminal simple.

Occurrence. ?Sakmarian, ?Artinskian, Lopingian with a late Changhsingian acme. Palaeo-Tethys from Greece to South China; Neo-Tethys: Taurides (Turkey), Zagros (southern Iran), Oman (Batain Plain). 


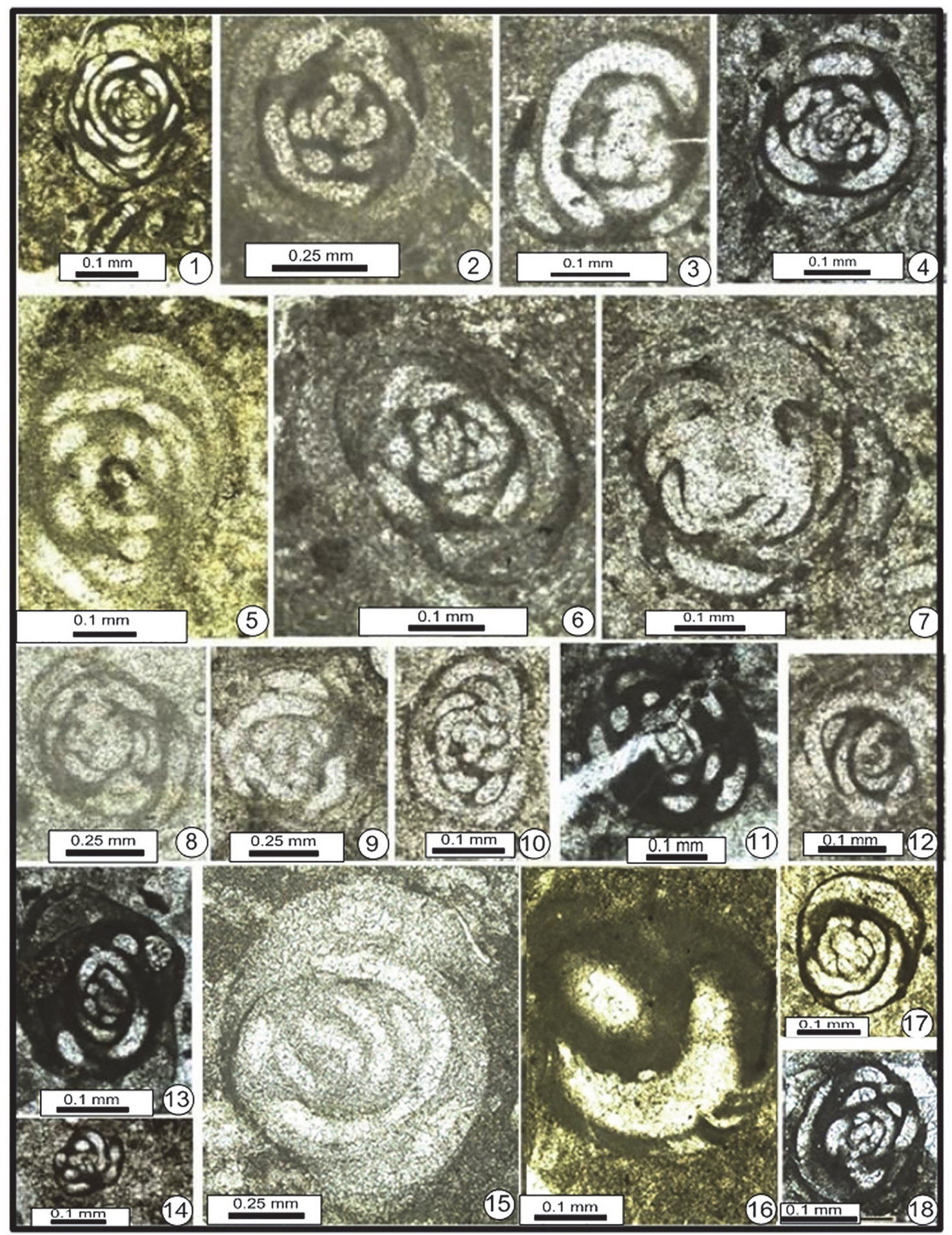

FIGURE 18. 1. Hemigordiellina? pulchrissima Ebrahim Nejad and Vachard $\mathrm{n}$. sp. Paratype (top) with Okimuraites plana (Okimura and Ishii, 1981) (bottom). P39-71. Midian. 2-4. Glomomidiella cf. problema (Lin, 1978). 2. P950. Murgabian. 3. with Hemigordiellina? sp. (bottom) P9-38. Murgabian. 4. P34 32. Midian. 5. Glomomidiella? sp. 5. P44-26. Djulfian. 6. Neodiscus milliloides Miklukho-Maklay, 1953. P9-18. Murgabian. 7, 15-16. Crassiglomella cf. guangxiensis (Lin, 1978) emend. Gaillot and Vachard, 2007. 7. P10-1. Murgabian. 15. P16- 44. Murgabian. 16. P4145. Latest Midian. 8-10, 12. Glomomidiella cf. problema (Lin, 1978). 8. P7-22. Murgabian. 9. P16 39. Murgabian. 10. P10-15. Murgabian. 12. P10-24. Murgabian. 11, 13-14, 17-18. Glomomidiella cf. gigantea (Lin, 1984). 11. P37-22. Midian. 13. P31-3. Midian. 14. P30-10. Earliest Midian. 17. P44-24. Djulfian. 18. P37-23. Midian. 
Genus GLOMOMIDIELLA Vachard, Rettori, Angiolini and Checconi, 2008

Type species. Glomomidiella nestellorum Vachard, Rettori, Angiolini and Checconi, 2008.

Description. Test spherical, rarely ovoid, involute, with rounded periphery and without umbilicus. Streptospirally coiled with the last few volutions rarely aligned. Spherical proloculus followed by an enrolled pseudoseptate second chamber gradually and proportionally increasing in size. Periphery margin broadly rounded. Two groups of specimens considered as megalospheric and microspheric generations. Wall calcareous porcelaneous, wellpreserved. The pseudoseptation produces a rugose inner periphery. Aperture simple at end of the tubular chamber.

Occurrence. Capitanian to Changhsingian. Palaeo-Tethys and Neo-Tethys: Tunisia, Croatia, Serbia, Hungary, Greece, Italy, Turkey, Iran, Himalaya, South China, Sumatra, and Malaysia.

Glomomidiella nestellorum Vachard, Rettori, Angiolini and Checconi, 2008

Figure 17.6-11

p. 1981 Glomospira spp.; Okimura and Ishii, pl. 2, figs. 6-7 (non figs. 2-5 = Hemigordiellina (sensu lato)).

1983b ?Kamurana; Jenny-Deshusses, pl. 20, figs. 3, 5.

?1995 Kamurana bronnimanni Altiner and Zaninetti; Partoazar, pl. 1(1), fig. 4, 1216.

v. 2008 Glomomidiella nestellorum Vachard, Rettori, Angiolini and Checconi, p. $354-356$, pl. 1 , figs. $1-19$, pl. 2, figs. 1 20 (with synonymy).

2004 Hemigordius ssp. (sic for spp.); Jenny et al., pl. 7, fig. 6 .

2009 Glomomidiella nestellorum Vachard, Rettori, Angiolini and Checconi; Song et al., fig. 8.33-34.

Description. Our specimens are consistent with the measurements of the type material.

Occurrence. As for the genus. Only abundant in one level of Maku (P30).

Glomomidiella cf. gigantea (Lin, 1984)

Figures 17.16-17, 18.11, 18.13-14, 18.17-18

?1981 Baisalina pulchra Reitlinger; Okimura and Ishii, p. 14-15, pl. 1, fig. 18.

1984 Baisalina giganta (sic) Lin, p. 127, pl. 3, figs. 22-23.
1995

Baisalina pulchra Reitlinger; Partoazar, pl. 2(1), figs. 1-5, pl. 4(1), fig. 1?, pl. 1(2), figs. 3-10, pl. 3(2), figs. 9-11.

?1995 Baisalina pulchra Reitlinger; BercziMakk, pl. 13, figs. 3-4, 6-7, pl. 14, figs. $4-5$, pl. 15 , fig. 6 ?.

1997 Neodiscus grandis (Lin, Li and Sun); Kobayashi, pl. 4, figs. 11-12.

2006b Baisalina sp.; Kobayashi, fig. 3.17-19.

v. 2008 Glomomidiella gigantea (Lin); Vachard et al., p. 354 (n. comb. orth. mut.; no illustration).

2011 Glomomidiella; Song et al., fig. 6.46.

Description. Although smaller than the species of Lin (1984), our material exhibits similar pseudosepta, irregular in length and location. The taxon described here is probably the direct ancestor of typical Baisalina pulchra Reitlinger, 1965. Besides, many false Baisalina pulchra from the literature are similar to Glomomidiella ex gr. gigantea (e.g., Lys in Montenat et al., 1976, pl. 17, fig. 4; Whittaker et al., 1979, pl. 1, figs. 1-7; Lys et al., 1980, pl. 2, figs. 2-4; Zaninetti et al., 1981, pl. 4, figs. 19-2; Okimura et al., 1985, pl. 1, fig. 9; Partoazar, 1995 and Berczki-Makk et al., 1995 (for these two latter, see the synonymy list)).

Occurrence. Midian Lopingian of Palaeo- and Neo-Tethys. Midian-Djulfian of Maku (P30, P31, P37 and P44).

Glomomidiella cf. problema (Lin, 1978)

Figures 17.22-17.24, 18.2-18.4, 18.8-18.10, 18.12

1978 Glomospira problema Lin, p. 11, pl. 1, figs. 6-7.

?1982 Neodiscus lianxanensis Hao and Lin, p. 27 , pl. 3, figs. $25-26$.

?1995 Foram. indet. sp.; Berczi-Makk et al., pl. 13, figs. 3-4, 6-7, pl. 14, figs. 4-5, pl. 15, fig. 6 ?.

?v. 1992 Baisalina (?) sp.; Fontaine et al., pl. 5, fig. 7 , pl. 20 , fig. 4 , pl. 35 , figs. 4, 7-9, pl. 36, figs. 1, 6-7, pl. 47, fig. 10.

?v. 2007 Neodiscus lianxanensis Hao and Lin; Gaillot and Vachard, p. 95, pl. 56, figs. 15-16 (with synonymy).

v. 2008 Glomomidiella problema (Lin); Vachard et al., p. 354 (n. comb. orth. mut.; no illustration).

v. 2009 Glomomidiella sp.; Mohtat-Aghai et al., pl. 1, fig. 16.

Description. Our specimens have a coiling which differs from that of $G$. cf gigantea being tighter in 
the beginning and with a thinner wall. This species is probably the transitional form between Glomomidiella and Crassiglomella.

Occurrence. Murgabian-earliest Djulfian of Maku (P7, P9, P10, P16, P31, P34, P40, P41, P44 and P47).

Glomomidiella? cf. specialisaeformis (Lin, Li and Sun, 1990) n. comb.

Figure 17.14-15, 17.18

1990 Hemigordius specialisaeformis Lin, Li and Sun, p. 216-217, pl. 26, figs. 1-3.

1995 Baisalina pulchra magna Lys; Partoazar, pl. 3(1), figs. 3-7.

Remark. This species seems to be the ancestor of Glomomidiellopsis Gaillot and Vachard, 2007, a characteristic genus of the Lopingian. It can be also transitional to Crassiglomella.

Occurrence. Midian-Djulfian of Maku (P31, P37, P39 and P47).

\section{Glomomidiella? sp. 5 \\ Figure 18.5}

Description. A unique specimen, the last whorls of which are aligned and give a compressed outline to the test, atypical for the genus.

Occurrence. Maku (P44).

Genus NEODISCUS Miklukho-Maklay, 1953 emend. Gaillot and Vachard, 2007

Type species. Neodiscus milliloides MiklukhoMaklay, 1953.

Synonyms. Glomospira Rzehak, 1885 (pars), Archaediscus Brady, 1873 (pars).

Description. Neodiscidae initially glomospiral and finally planispiral involute to semi-involute. Buttresses well developed. All volutions exhibit a high lumen.

Composition. Neodiscus milliloides MiklukhoMaklay, 1953; N. eximius Lin, Li and Sun, 1990; N. grandis Lin, Li and Sun, 1990; Neodiscus lianxianensis Hao and Lin, 1982; N. orbicus Lin, 1984; N. ovatus sensu Lin, Li and Sun, 1990 or sensu Ueno, 1992 non Grozdilova, 1956; N. plectogyraeformis Lin, Li and Sun, 1990; N. scitus Lin, 1984; Agathammina sp. B sensu Kobayashi, 1988, pl. 2, figs. 15, 22 (probably transitional to Crassiglomella n. gen.); Hemigordius reicheli globulus nom. nud. Altiner, 1981, pl. 44, figs. 11-13; Kamurana or Neodiscus sp. sensu Altiner and Özkan-Altiner, 1998, pl. 4, fig. 19; Neohemigordius maopingensis Wang and Sun, 1973 (part.).

Occurrence. Changhsingian of NW Caucasus (Miklukho-Maklay, 1953: indicated also as present in the Early Triassic). Midian of Oman (Vachard et al., 2002), Tunisia and central Japan, Changhsingian of Greece (Vachard et al., 1993a, b). Turkey (discovered in Hazro; present in Himmetli: D.V. unpublished data), and South China.

Neodiscus milliloides Miklukho-Maklay, 1953

Figures 8.8?, 17.12-13, 17.19, 18.6

1953 Neodiscus milliloides Miklukho-Maklay, p. 129, pl. 6, fig. 6.

?1981 Hemigordius abadehensis Okimura and Ishii, p. 16-17, pl. 1, figs.19-20.

?1988 Kamurana broennimanni Altiner and Zaninetti; Pronina, pl. 1, figs. 13-14.

2006a Neodiscus padangensis (Lange); Kobayashi, fig. 4.1-13, 4.21.

v. 2007 Neodiscus milliloides Miklukho-Maklay; Gaillot and Vachard, p. 95, pl. 21, fig. 3 ?, pl. 27, figs. $14-15$, pl. 53, figs. 1,7 , pl. 54, fig. 2?, pl. 71, figs. 7 ?, 8?

? $2011 \quad$ Multidiscus; Song et al., fig. 6.48.

Description. Neodiscus ovoid, slightly asymmetrical, last whorls aligned, involute to semi-evolute. D $=(0.640)-1.100-1.550 \mathrm{~mm}$ (type material: 2.000$2.500 \mathrm{~mm}), \mathrm{w}=0.730-0.910 \mathrm{~mm}$ (type material $=$ $1.000-1.600 \mathrm{~mm}), w / D=0.66-0.69, p=(0.060)$ $0.090 \mathrm{~mm}, \mathrm{n}=6-7, \mathrm{~h}=0.100-0.145 \mathrm{~mm}, \mathrm{~s}=0.050-$ $0.060 \mathrm{~mm}$.

Occurrence. ?Murgabian-?Midian of Armenia. Late Midian of Sumatra and central Japan. ?Kalabagh Member of Salt Range (Pakistan). Late Changhsingian of NW Caucasus, South China and Zagros. Murgabian-Djulfian in Maku (P9, P10?, P20, P21, P30, P31, P37, P38, P50 and P55).

Genus CRASSIGLOMELLA Gaillot and Vachard, 2007

Type species. Glomospira guangxiensis Lin, 1978.

Synonym. Glomospira Rzehak, 1885 (part.).

Description. Neodiscidae entirely glomospiral, showing well developed buttresses and a high lumen of the whorls.

Composition. Glomospira guangxiensis Lin, 1978; Agathammina pusilla sensu Berczi-Makk, 1978, pl. 1, fig. 1; A. pusulla (sic) sensu Nguyen Duc Tien, 1986a, pl. 5, fig. 5; A. sp. A sensu Kobayashi, 1988, pl. 2, figs. 7-12; Foram. Indet. sp. sensu Berczi-Makk et al., 1995, pl. 15, figs. 1-3; ?Baisalina pulchra sensu Berczi-Makk et al., 1995, pl. 13, figs. 3-4, 6-7, pl. 14, figs. 4-5, pl. 15, fig. 6?

Comparison. It differs from the other Neodiscidae by the entirely glomospiral coiling, and from the Glomospira auctorum (= Hemigordiellina Marie in Deleau and Marie, 1961 sensu Vachard in Vachard 
and Beckary, 1991) by the large size and the buttresses.

Occurrence. Midian of Oman (Vachard et al., 2002) and central Japan (Kobayashi, 1988, reinterpreted). Lopingian of Cambodgia (Nguyen Duc Tien, 1986a). Changhsingian of Greece (Vachard et al., 1993a, b). Turkey (discovered in Hazro; also present in Himmetli, Vachard unpublished data). South China. Zagros and Fars (Iran) (Gaillot, 2006). Murgabian to Djulfian of Maku (P6, P7, P9, P10, P16?, P20, P21, P31, P44 and P54).

Crassiglomella cf. guangxiensis (Lin, 1978) emend. Gaillot and Vachard, 2007

Figures 17.24, 18.7, 18.15-18.16

1965 Glomospira sp.; Kochansky-Devidé, pl. 13 , figs. 7-8.

? 1973 Hemigordius sp.; Bozorgnia, pl. 41, figs. 1, 3.

1978 Glomospira guangxiensis Lin, p. 11, pl. 1, figs. 2-3.

?1981 Hemigordius reicheli Lys; Altiner, pl. 44, figs. 9-10 (see below).

?1990 Neodiscus maopingensis (Wang and Sun); Lin et al., p. 202, pl. 22, figs. 7-8.

1990 Glomospira guangxiensis Lin; Lin et al., p. 86 (no illustration).

1991 Hemigordius; Baud et al., pl. 1, fig. 1, pl. 2, fig. 1?

v. 1993a Multidiscus ex gr. padangensis (Lange); Vachard et al., pl .6, figs. 1, 3.

v. 1993a Neodiscus milliloides MilklukhoMaclay (sic); Vachard et al., pl. 6, figs. 4-7.

v. 1993a Kamurana? sp.; Vachard et al., pl. 6, fig. 6.

v. 1993b Glomospira [(?) ou Kamurana (?)] guangxiensis Lin; Vachard et al., pl. 8, fig. 3.

2001 Kamurana? sp.; Ueno, pl. 2, fig. 10.

non 2002 Glomospira guangxiensis Lin; Gu et al., p. 165, pl. 1, fig. 23 (a Hemigordiellina).

v. 2002 "Glomospira" ex gr. guangxiensis Lin; Vachard et al., pl. 6, fig. 1.

v. 2006 Crassiglomella guangxiensis (Lin); Gaillot, p. 111-112, pl. Il.26, figs. 14, 16, pl. IV.4, fig. 12, pl. VI. 7 , figs. 14 , $17 ?$ v. 2007 Crassiglomella guangxiensis (Lin); Gaillot and Vachard, p. 96, pl. 22, figs. 14, 17?, pl. 54, figs. 14, 16.

v. 2009 Crassiglomella sp.; Mohtat-Aghai et al., pl. 1, fig. 13-15, pl. 2, fig. 1.

Description. Buttresses very developed. Last whorl partially involute. Large diameter but remaining always inframillimetric for 5-6 whorls. Diameter $(D)=0.500-0.900 \mathrm{~mm}$; width $(\mathrm{w})=0.400-0.600$ $\mathrm{mm} ; \mathrm{w} / \mathrm{D}$ ratio $=0.70-0.90$; number of volutions: 5 6 ; height of last volution $=0.100-0.200 \mathrm{~mm}$; wall thickness $=0.020-0.050 \mathrm{~mm}$.

Remarks. The type of sections and/or growths of the individuals are very diverse. Hence, some sections can be interpreted as Neodiscus or Multidiscus (see Bozorgnia, 1973; Altiner, 1981; Vachard et al., 1993a or Lin et al, 1990). An unpublished material from Hazro (Turkey) showed us that the taxa Glomospira guangxiensis, Multidiscus arpaensis and Neodiscus cf. milliloides in the sense of Vachard et al. (1993a) correspond in reality to the unique species Crassiglomella guangxiensis.

Occurrence. Midian of Oman, Midian of Yunnan (Ueno, 2001, updated by Gaillot and Vachard, 2007). Lopingian of Croatia and Hungary. Wuchiapingian of South China. Changhsingian of Greece, Turkey, and South China. Late Changhsingian of Abu Dhabi. Latest Changhsingian of Offshore Fars (Iran). Midian of Maku (P34, P38 and P 44).

Class NODOSARIATA Mikhalevich, 1993 Superfamily ROBULOIDOIDEA Reiss, 1963 nom. translat. Loeblich and Tappan, 1984 emend. Gaillot and Vachard, 2007

Family SYZRANIIDAE Vachard in Vachard and Montenat, 1981

Remarks. The original definition is confirmed here: tubular Nodosarioidea without septation or with faint pseudosepta.

Composition. Syzrania Reitlinger, 1950; Syzranella Mamet and Pinard, 1992; Amphoratheca Mamet and Pinard, 1992; Tezaquina Vachard in Vachard and Montenat, 1981 non Vachard, 1980; ?Vervilleina Groves in Groves and Boardman, 1999 (this latter possesses more complete septa, and might be alternatively assigned to the Protonodosariidae).

Occurrence. Late early Moscovian to late Changhsingian, cosmopolite during the Pennsylvanian and Cisuralian, posteriorly limited to Neo-Tethyan and Palaeo-Tethyan.

Genus SYZRANIA Reitlinger, 1950

Type species. Syzrania bella Reitlinger, 1950. 
Decription. Test cylindical, bilocular, undivided, with a proloculus followed by a chamber. Wall bilayered with an outer hyaline fibrous layer and an inner, microgranular wall. Aperture terminal simple. Remark. This genus is the most primitive taxon with a hyaline wall, and consequently, it is the ancestor of all the hyaline foraminifers (Rotaliata sensu lato) currently dominant among the group.

Occurrence. Moscovian-Changhsingian, cosmopolite from Moscovian to Artinskian; then, only Tethyan.

\section{Syzrania n. sp.?}

Figures 16.3, 18.1-3

1988a Syzrania sp.; Pronina, pl. 2, fig. 1.

v. 2007 Syzrania? sp.; Gaillot and Vachard, pl. 85, figs. $10,12$.

Description. Test similar to a large Syzrania; i.e., with thick outer hyaline wall, thin inner microgranular layer, cylindrical, no septation. Proloculus not observed. Length $=0.780-0.950 \mathrm{~mm}$; outer diameter $(D)=0.250-0.280 \mathrm{~mm}$; inner diameter $(\mathrm{d})=$ $0.170-0.200 \mathrm{~mm}$; $\mathrm{d} / \mathrm{D}$ ratio $=0.30-0.41$; wall thickness $=0.035-0.050 \mathrm{~mm}$.

Occurrence. Dorashamian of Armenia. Lopingian of Zagros and Guadalupian (Murgabian to Midian) of Maku (P6, P9 and P32).

Genus RECTOSTIPULINA Jenny-Deshusses, 1985 emend. Gaillot and Vachard, 2007

Type species. Rectostipulina quadrata JennyDeshusses, 1985.

Synonym. Stipulina Lys in Lys and Marcoux, 1978 (nomen nudum: no type species designated and/or described).

Description. Test tubular, small, undivided (or very rarely faintly divided), generally quadrate in transverse section. Wall hyaline yellowish. Proloculus are very rarely observed but present.

Discussion. Although criticized by Altiner and Savini (1997) and Groves (2000), the assignment of Rectostipulina to the Syzraniidae (Vachard and Montenat, 1981) or the Nodosariidae (Fontaine and Nguyen Duc Tien, 1989) is confirmed by the observation of some proloculi (Gaillot, 2006, pl. I.26, fig.10). Another proloculus of Rectostipulina was also published as "Syzrania sp." by Pronina (1988a: pl. 2, fig. 1; 1989: pl. 1, fig. 1). The proloculi of Rectostipulina are very rarely conspicuous, but similarly, Permian Earlandia seem to lack of proloculus and were erroneously separated as the distinct genus Aeolisaccus, but they exist in approximately 2 for 1000 sections (see Gaillot, 2006). Furthermore, Rectostipulina possesses clearly a nodosariin wall, easily comparable with the representatives of this suborder always very abundant with the Rectostipulina. It is impossible to conclude if Giraliarella Crespin, 1958 is a junior synonym or not of Rectostipulina, because another homeomorph exists: Chitralina Angiolini and Rettori, 1994, which possesses a microgranular wall, and is probably, although it lacks also of proloculus, an earlandioid foraminifer (see also ArnaudVanneau, 1980).

Composition. Rectostipulina quadrata JennyDeshusses, 1985; R. pentamerata Groves, Altiner and Rettori, 2005; $R$. syzranaeformis Gaillot and Vachard, 2007; R. hexacamerata Song and Tong in Song et al., 2009.

Occurrence. Rectostipulina is Midian-Lopingian in age in Palaeo-Tethys and Neo-Tethys. Pronina (1995) considered its FAD as Djulfian (= Wuchiapingian). Our material demonstrates the presence since the late Midian. Until now, the genus was known in the Lopingian of Cyprus, Afghanistan, Turkey, Greece, Alborz, Zagros, Armenia, Ladakh, West Thailand (Nguyen Duc Tien, 1988; Fontaine and Nguyen Duc Tien, 1989), Cambodgia (Nguyen Duc Tien, 1986a), Saudi Arabia (Vachard et al., 2005), and Yunnan (Ueno et al., 2010).

Rectostipulina quadrata Jenny-Deshusses, 1985 Figure 19.4-19.5

1965 Coupe d'un proloculum (Nodosaridaire?); Sellier de Civrieux and Dessauvagie, fig. 24.41 in text p. 152.

1985 Rectostipulina quadrata JennyDeshusses, p. 153-157, pl. 1, figs. 1-7.

1986a Stipulina?; Nguyen Duc Tien, pl. 1, fig. 4.

1988 Rectostipulina quatrata (sic) JennyDeshusses; Nguyen Duc Tien, p. 109, pl. 9, figs. 1-6.

1989 Rectostipulina quadrata JennyDeshusses; Fontaine and Nguyen Duc Tien, p. 120, 122, pl. 1, figs. 1-10, 14, 18 (non figs. 11-13, 15-18 part. = ?Donezella lutugini), pl. 2, figs. 1-6, 89 (part.) (non figs. 7, 9 (part.), 11-12, $14=$ ?D. lutugini) (with synonymy).

v. 1993a Rectostipulina quadrata JennyDeshusses; Vachard et al., pl. 7, figs. 10-12.

1995 Stipulina lysi Partoazar, pl. 2(1), fig. 19, pl. 1(3), fig. 1 (nom. nud.).

v. 2005 Rectostipulina sp.; Vachard et al., p. 166 , pl. 6 , fig. 8. 


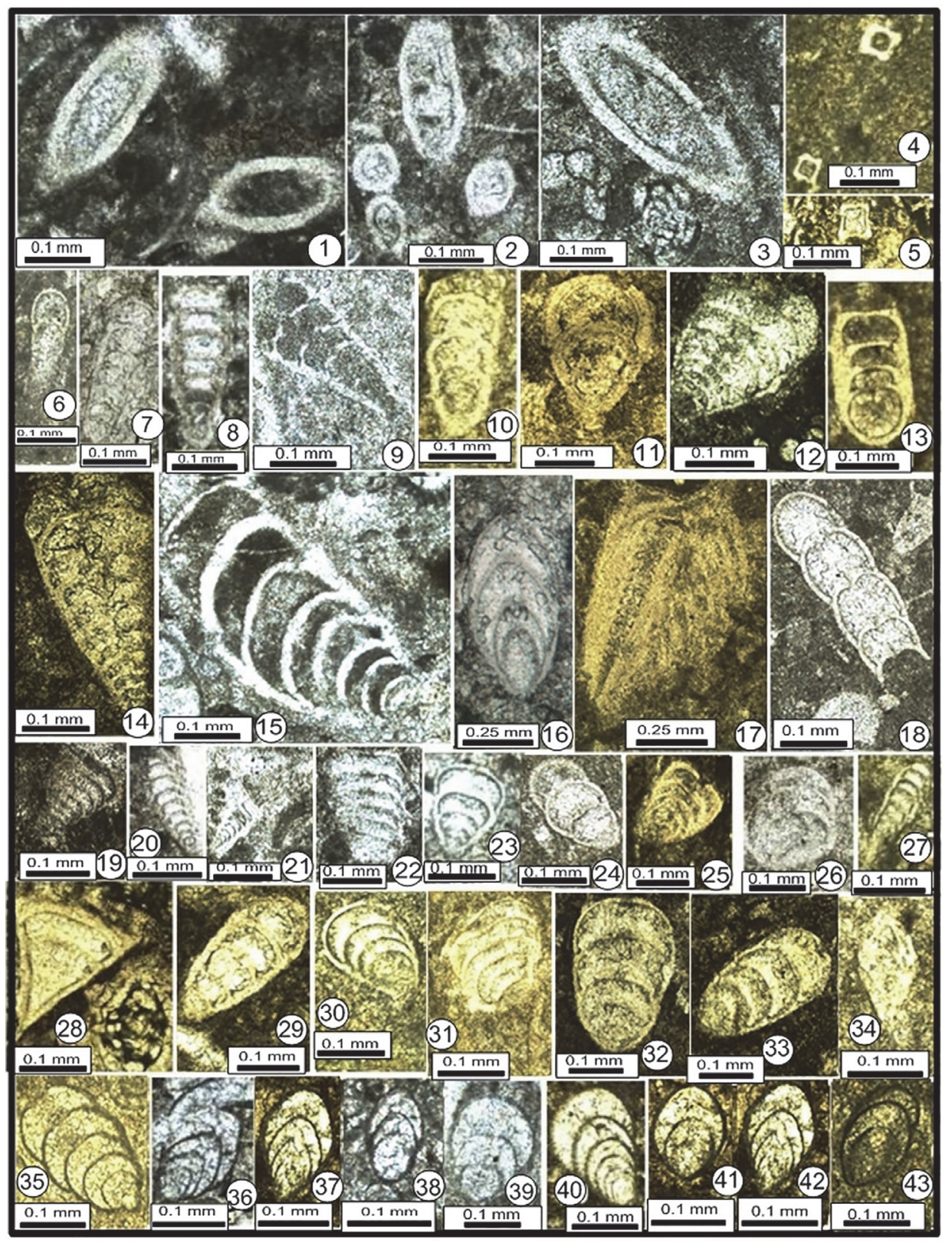

FIGURE 19. 1-3. Syzrania n. sp.? 1. P32-14. Midian. 3. With Globivalvulina and Hemigordiellina. P32-31. Midian. 45. Rectostipulina quadrata Jenny-Deshusses, 1985. 4. P50-35. Djulfian. 5. P47-6. Djulfian. 6. Protonodosaria cf. sagitta (Miklukho-Maklay, 1954). P9-11. Murgabian. 7-10, 29. Nodosinelloides spp. 7. P25-15. Murgabian. 8. P34-40. Midian. 9. P1-23. Murgabian. 10. P51-19. Djulfian. 29. P41-25. Latest Midian. 11. Langella perforata (Lange, 1925). Axial section. P56-9. Djulfian. 12, 19-22, 27, 31. Geinitzina sp. 12. P39-9. Midian. 19. P1-23. Murgabian. 20. P6-9. Murgabian. 21. P20-8. Murgabian. 22. P27-50. Murgabian. 27. P50-31. Djulfian. 31. P54-22. Djulfian. 13, 26. Pachyphloia ex gr. ovata Lange, 1925. 13. Frontal axial section. P54-5. Djulfian. 26. Sagittal axial section. P10-21. Murgabian. 14, 28. Pseudotristix sp. 14. Axial section. P41-24. Latest Midian. 28. subtransverse section with Hemigordiellina regularis. P47-43. Early Djulfian. 15. Pseudolangella? sp. Oblique section. P8-51. Murgabian. 16. Lingulina cf. imaginaria Pronina, 1999. P3. Early Murgabian. 17. Pachyphloia cf. iranica Bozorgnia, 1973. P41-46. Latest Midian. 18. Pseudolangella sp. P9-46. Murgabian. 23-24, 30, 32-33. Frondicularia sp. 23. P8-18. Murgabian. 24. P9-23. Murgabian. 30. P50-32. Djulfian. 32. P41-34. Latest Midian. 33. P39-52. Midian. 25. Colaniella aff. minuta Okimura, 1988. P41-37. Djulfian. 34. Robuloides lens Reichel, 1946. Axial section. P50-15. Djulfian. 35, 39-41, 43. Frondina permica Sellier de Civrieux and Dessauvagie, 1965. 35. P54-25. Djulfian. 39. P37-19. Midian. 40. P49-5. Djulfian. 41. P49-8. Djulfian. 43. P50-23. Djulfian. 36-38. Ichthyofrondina palmata (Wang, 1974). 36. P34-25. Midian. 37. P34-34. Midian. 38. P34-41. Midian. 42. P49-14. Djulfian. 
2005 Rectostipulina quadrata JennyDeshusses; Groves et al., p. 29-30, fig. 23.5-12 (with synonymy).

v. 2006 Rectostipulina quadrata JennyDeshusses; Gaillot, p. 127-128, pl. I.27, fig. 17, pl. I.31, figs. 9, 11, pl. I.41, fig. 7 , pl. II.27, figs. 1, 12, pl. III.10, fig. 14, pl. III.11, fig. 15, pl. III.12, fig. 12, pl. III.20, figs. 3,13 , pl. III.26, fig. 27 , pl. III.27, fig. 14, pl. V.6, fig. 8, pl. VI.13, figs. 4-5.

2007 Rectostipulina quadrata JennyDeshusses; Groves et al., fig. 6.9, fig. 7.1-3.

v. 2007 Rectostipulina quadrata JennyDeshusses; Gaillot and Vachard, pl. 63 , fig. 27 , pl. 73 , fig. 17 , pl. 75 , fig. 7 , pl. 76 , figs. 1,12 , pl. 77 , fig. 14 , pl. 78 , fig. 15 , pl. 79 , fig. 12 , pl. 80 , figs. 3,13 , pl. 81 , fig. 14 , pl. 82 , figs. $4-5$, pl. 87 , figs. 9, 11.

2009 Rectostipulina quadrata JennyDeshusses; Song et al., fig. 11.4-11.5.

2009 Rectostipulina quadrata JennyDeshusses; Ueno and Tsutsumi, figs. 9.20-9.21, 11.22.

2009 Rectostipulina quadrata JennyDeshusses; Nestell et al., pl. 2, fig. 1.

2010 Rectostipulina quadrata JennyDeshusses; Angiolini et al., fig. 4.304.31.

2010 Rectostipulina quadrata JennyDeshusses; Ueno et al., figs. 5.17, 6.8.

2012 Rectostipulina quadrata JennyDeshusses; Wignall et al., fig. 10J.

Remarks. Proloculus in section and complete longitudinal sections are very rare. Hence, the argument of the absence of proloculus is not definitive to exclude this taxon from the foraminifers, compared to the type of microstructure, entirely similar to the well characterized nodosariids contained in the same thin sections.

Occurrence. Lopingian of Turkey, Cyprus, Greece, northern Italy, Alborz, Zagros, Armenia, Saudi Arabia, Afghanistan, Ladakh, western Thailand, Cambodgia, Yunnan, New Zealand (e.g., Nguyen Duc Tien, 1986a, 1988; Fontaine and Nguyen Duc Tien, 1989; Vachard et al., 2005; Groves et al., 2005, 2007; Ueno et al., 2010). Djulfian of Maku (P40?, P47, P50 and P51).

Family PROTONODOSARIIDAE Mamet and Pinard, 1992 emend. Gaillot and Vachard, 2007
Subfamily PROTONODOSARIINAE Mamet and

Pinard, 1992 nom. translat. Gaillot and Vachard, 2007

Genus PROTONODOSARIA Gerke, 1959 emend. Sellier de Civrieux and Dessauvagie, 1965

Type species. Protonodosaria proceraeformis Gerke, 1959 orth. mut. Vachard et al., 2005.

Description. Cylindrical test, initially slightly tapering. Chambers uniseriate, hemispherical, increasing slowly in height, with depressed sutures. Wall fibrous monolayered. Aperture rounded, simple, terminal.

Composition. See Gaillot and Vachard (2007).

Occurrence. Late Pennsylvanian (Kasimovian)Late Permian, probably cosmopolite.

Protonodosaria cf. sagitta (Miklukho-Maklay, 1954) Figure 19.6

To compare with:

1954 Nodosaria sagitta Miklukho-Maklay, 1954, p. 27-28, pl. 2, fig. 14.

?2005 Nodosinelloides sagitta (MiklukhoMaklay); Groves et al., p. 17, fig. 18.14-18-21, 18.23-18.30 (with synonymy).

2005 Polarisella sagitta (Miklukho-Maklay); Hughes, pl. 3, fig. 12.

2009 Nodosinelloides sagitta (MiklukhoMaklay); Song et al., fig. 11.17-21.

2009 Polarisella sagitta (Miklukho-Maklay); Ueno and Tsutsumi, fig. 9.17.

Description. This species is characterized by its small test, thin hyaline wall, subquadratic chambers relatively high. Initially tapering, the test becomes rapidly cylindrical. Sutures of chambers are faint. $\mathrm{H}=0.500-0.600 \mathrm{~mm}, \mathrm{w}=0.035-0.050$ $\mathrm{mm}, \mathrm{w} / \mathrm{H}=0.25-0.33, \mathrm{n}=$ probably $5-6), \mathrm{h}=0.150-$ $0.200 \mathrm{~mm}, \mathrm{~s}=0.005-0.007 \mathrm{~mm}$. Our unique oblique section is incomplete but its similarity with $P$. sagitta is great. This species was already mentioned among the Alborz microfaunas by JennyDeshusses (1983b, p. 158, pl. 5, fig. 7).

Remark. An areal aperture is unquestionably present; therefore, this species belongs to Protonodosaria rather than Nodosinelloides. Although homeomorph, the specimens of Groves et al. (2005) are doubtful because their test is definitely bilayered. Our specimens are rare and insufficient to confirm the specific name.

Occurrence. Late Permian of northern Caucasus, Croatia, Japan, Ladakh, Taurus, NW Turkey, and South China. Murgabian-Djulfian of Maku (P3, P9?, P54 and P55). 
Protonodosaria aff. globifrondina Sellier de Civrieux and Dessauvagie, 1965

Figure 19.18

To compare with:

1965 Protonodosaria globifrondina Sellier de Civrieux and Dessauvagie, p. 67, pl. 5, fig. 24, pl. 9, fig. 5, pl. 15, fig. 1 , pl. 16, fig. 7.

1978 Protonodosaria globifrondina; Lys et al., pl. 8, figs. 9, 13.

1979 Protonodosaria globifrondina; Nguyen Duc Tien, p. 92-93, pl. 6, fig. 12.

1984 Protonodosaria globifrondina; Altiner, pl. 2, fig. 20.

1986a Protonodosaria globifrondina; Nguyen Duc Tien, pl. 2, fig. 12.

1989 Protonodosaria globifrondina; Köyluoglu and Altiner, pl. 9, fig. 20.

1994 Protonodosaria globifrondina; Fontaine et al., pl. 6, fig. 2.

Description. Test characterized by relatively embracing chambers, and septal and wall thicknesses relatively thin, and constant in size. Our unique section is oblique and broken, but might correspond to this species described in this genus.

Occurrence. FAD probably Midian-LAD Changhsingian; southern Turkey, Alborz, Himalaya, Malaysia and Cambodgia (i.e., a Perigondwanan and Indosinian species). Rare in Maku (P9, P35 and P55).

\section{Genus NODOSINELLOIDES Mamet and Pinard, 1992}

Type species. Nodosinelloides potievskayae Mamet and Pinard, 1996 (nomen novum for Nodosaria gracilis Potievskaya, 1962 preoccupied).

Description. Test subcylindrical, chambers generally hemispherical, not enveloping, increasing very slowly in height and width. Wall two layered with an ancestral microgranular inner layer and a typical fibrous outer layer (the corresponding evolutive stage of the archaediscids would be the concavus stage; e.g., Vachard, 1988). Lateral wall and septal wall are equal in thickness. Aperture terminal, simple, rounded, often not observable in section.

Composition. See Gaillot and Vachard (2007).

Occurrence. Late Pennsylvanian-Late Permian.

\section{Nodosinelloides spp.}

Figure 19.7-10, 19.29

Remark. Although ordinarily abundant in the Middle/Late Permian limestones, this genus is rare in our material.
Occcurrence. All the series of Maku (P1, P6, P23, P25, P32, P34, P35(2), P41, P50, P51, P55 and P56).

Subfamily LANGELLINAE Gaillot and Vachard, 2007

Genus LANGELLA Sellier de Civrieux and Dessauvagie, 1965

Type species. Padangia perforata Lange, 1925.

Description. Test small, medium, large or very large (height from 0.3 to $1.7 \mathrm{~mm}$ according to Sellier de Civrieux and Dessauvagie (1965) and up to $3.0 \mathrm{~mm}$ (Gaillot and Vachard, 2007)). From 4 to 11 chambers. Tapering cylindrical test, slightly compressed or not. Sagittal axial section oval, to triangular or bitriangular. Frontal axial section similar but more compressed. Transverse section circular to ovate. Absence of test nor proloculus ornementation. Aperture rarely observed in thin section; if present, it is simple, cylindrical, and lacking of particularities. Sutures absent. Chambers increase rapidly in height. Septa increase generally in thickness, except the last one generally thinner than the penultimate. Chambers curved, non-enveloping, relatively low at the beginning but becoming relatively high to high in the last part. Wall thick by covering of the successive layers, occasionally obviously lamellate. Some species seem to exhibit an "angulatus" stage as observed in the genus Nestellorella Gaillot and Vachard, 2007 (i.e., Langella conica sensu Bozorgnia, 1973 (part.), pl. 34, fig. 1 , whereas p. 36 , fig. 6 is really a Nestellorella). Composition. See Gaillot and Vachard (2007).

Occurrence. Rare in the Yakhtashian-Bolorian (= Longlingian of South China = Kungurian of Urals), acme in SE Asia during the Midian. LAD in the Changhsingian, Palaeo- and Neo-Tethys.

\section{Langella perforata (Lange, 1925)}

Figure 17.11

1925 Padangia perforata Lange, p. 228-229, pl. 1, figs. 21a-b.

v. 2007 Langella ex gr. perforata (Lange); Gaillot and Vachard, p. 122-123, pl. 89, fig. 23, pl. 94, fig. 5.

Description. Only one immature species was observed but the shape of the chambers and the microstructure of the wall are typical of this species.

Occurrence. Midian of Sumatra, Turkey, Afghanistan, Russia, NW Caucasus, Armenia, Thailand, Sarawak, Malaysia and Iran (Alborz). Lopingian of South China and Zagros, and Djulfian of Maku (P56). 
Genus PSEUDOLANGELLA Sellier de Civrieux and Dessauvagie, 1965

Type species. Pseudolangella fragilis Sellier de Civrieux and Dessauvagie, 1965.

Description. Test small to submillimetric (Height $=$ $0.300-0.900 \mathrm{~mm}$ ), with five to nine chambers. Sagittal axial section tapering. Frontal axial section compressed. Transverse section circular. Absence of ornementation of the test or proloculus. Aperture generally absent in thin-section or simple, cylindrical, without peculiar characteristics. Sutures absent. Chambers increase regularly in height. Septa increase weakly in thickness. Chambers curved, non-enveloping, relatively low at the beginning but becoming relatively high in the last part. Wall proportionally thin.

Occurrence. FAD probably Sakmarian-LAD Changhsingian in Palaeo- and Neo-Tethys. Maku (P6, P9, P10, P25, P35, P40 and P49).

\section{Pseudolangella? sp.}

Figure 19.15

Remark. Only an oblique section of great size might be related to this genus; nevertheless, all the chambers remain relatively low.

Occurrence. Early Murgabian of Maku (P8).

Family GEINITZINIDAE Bozorgnia, 1973 Genus GEINITZINA Spandel, 1901

Type species. Geinitzina postcarbonica Spandel, 1901.

Occurrence. Latest Pennsylvanian (Groves, 2000)-Permian, cosmopolite, up to Changhsingian (Lin et al., 1990).

Geinitzina sp.

Figure 19.12, 19.19-22, 19.27, 19.31

Description. The Geinitzina are poorly represented in our material, and apparently by a undetermined small species.

Occurrence. Murgabian-Djulfian of Maku (P1, P6, P8, P9, P20, P21, P23, P27, P31, P35, P35(2), P39, P40, P50 and P54).

\section{Genus FRONDICULARIA sensu Sellier de Civreux} and Dessauvagie, 1965

Type species. Renulina complanata Defrance, 1824.

Description. Biconical test, with long lower cone and small upper cone. Chambers low, broad and palmate to horseshoe-shaped. Aperture terminal, central, radiate, sometimes with a small neck.

Occurrence. Sakmarian to latest Changhsingian (Gaillot and Vachard, 2007).
Frondicularia sp.

Figure 19.23-19.24, 19.30, 19.32-33

Remark. This undetermined species is sporadic in our material (P8, P9, P39, P41 and P50).

Genus PSEUDOTRISTIX Miklukho-Maklay, 1960

Type species. Tristix (Pseudotristix) tcherdynzevi Miklukho-Maklay, 1960.

Synonym. Multifarina Lin, 1984.

Description. Similar to Geinitzina, but with an uniseriate development becoming triserial or with three diverging series of chambers.

Occurrence. The taxon is generally cited in the Wuchiapingian/Djulfian, from Turkey to South China (including Multifarina where it is indicated as Maokouan in age by Lin et al., 1990, p. 89). Its FAD seems to be late Midian in Sumatra, central Japan and Russia (Podvolzhya, Prekama, and Primorye), and its LAD is Changhsingian in age in Armenia, Italy, Cambodgia, South China, Yunnan, northern Thailand, Japan and Zagros.

Pseudotristix sp.

Figure 19.14, 19.28

Remark. These rare representatives of the genus correspond probably to a new species.

Occurrence. Latest Midian-Djulfian of Maku (P41, P47 and P51).

Family ROBULOIDIDAE Reiss, 1963 nom. translat. Loeblich and Tappan, 1984

Synonym. Eocristellariidae Loeblich and Tappan, 1984 (although this latter family was originally assigned to the Fusulinata).

Description. Planispirally coiled Robuloidoidea, sometimes secondarily uncoiled.

Occurrence. Earliest to latest Permian. Palaeoand Neo-Tethys.

Genus ROBULOIDES Reichel, 1946

Type species. Robuloides lens Reichel, 1946.

Occurrence. Midian-latest Changhsingian of Greece (Hydra, Attica), Cyprus, Hungary, Turkey, NW Caucasus, Armenia, Afghanistan, Salt Range, South China, Primorye, Japan and New Zealand.

Robuloides lens Reichel, 1946

Figure 19.34

1946 Robuloides lens Reichel, p. 536, textfigs. 21-26, pl. 19, figs. 6-7.

1981 Robuloides lens Reichel; Okimura and Ishii, p. 18-19, pl. 1, fig. 5.

non 1997 Robuloides lens Reichel; Kobayashi, pl. 5, figs. 7-10 (= Robuloides acutus Reichel or another species). 
v. 2005 Robuloides lens Reichel; Vachard et al., p. 170-171, pl. 6.9.

2005 Robuloides lens Reichel; Groves et al., p. 32-33, fig. 24.3-7, 24.10-13 (with synonymy).

non 2009 Robuloides lens Reichel; Song et al., fig. 10.33-35 (= R. acutus).

2009 Robuloides acutus Reichel; Nestell et al., pl. 2, figs. 22-25.

non 2010 Robuloides lens Reichel; Angiolini et al., fig. 4.32 (= Pararobuloides).

Description. Very rare but typical specimens.

Occurrence. Midian-Late Permian of Turkey, Greece (Attica), northern Italy, NW Caucasus, Armenia, Iran (Abadeh), Salt Range, Japan, South China, New Zealand (according to Groves et al., 2005, p. 33). Duhaysan Member (late Djulfian) of Saudi Arabia (Vachard et al., 2005). Djulfian of Maku (P45? and P50).

Family FRONDINIDAE Gaillot and Vachard, 2007

Description. A family of Nodosarioidea relatively common during the Midian/Capitanian and Late Permian. This family is characterized by its dark (microgranular hyaline) wall and the embracing shape of the chambers. The apertures, areal and simple, are smooth or accompanied by an internal neck.

Comparison. This family differs from all other ones of the Nodosarioidea by the return to a dark wall (i.e., that of the earliest ancestor Earlandia; see Vachard, 1994), whereas the members of the family are rigorously homeomorphous with some typical Nodosarioidea such as Ichthyolaria Wedekind, 1937. The link between Protonodosariidae and Frondinidae can be represented by the genus Tauridia Sellier de Civrieux and Dessauvagie, 1965 emend. Gaillot and Vachard, 2007 which exhibits a partial disappearance of the yellow external layer of the wall.

Occurrence. Capitanian-Changhsingian. Palaeoand Neo-Tethys.

\section{Genus FRONDINA Sellier de Civrieux and} Dessauvagie, 1965

Type species. Frondina permica Sellier de Civrieux and Dessauvagie, 1965.

Synonyms. Ichthyofrondina (part.); Lingulina (part.); Pseudoglandulina sp.; Ichthyolaria (part.); Frondicularia (part.).

Description. Test uniseriate with rectilinear axis of development. Chambers horseshoe shaped to semi-ellipsoidal, weakly enveloping to evolute. Wall hyaline but apparently dark. Aperture simple, terminal, central, with two inner oral tongues.

Composition. See Gaillot and Vachard (2007).

Occurrence. Late Midian-Changhsinghian, Palaeo- and Neo-Tethyan (Turkey, Iran, NW Caucasus, Armenia, NWThailand, South China, Japan, New Zealand; Gaillot and Vachard, 2007)

Frondina permica Sellier de Civrieux and Dessauvagie, 1965

Figure 19.35, 19.39-19.41, 19.43

1965 Frondina permica Sellier de Civrieux and Dessauvagie, p. 59-60, pl. 5, figs. 17-18, 21-23, 26-28, 32-33.

?1981 Lingulina sp. cf. L. elegantula (M-Maklay); Okimura and Ishii, p. 17-18, pl. 1, fig. 12.

1995 Frondina permica Sellier de Civrieux and Dessauvagie; Partoazar, pl. 2(1), figs. 12, 18.

1997 Lunucammina sp. B; Kobayashi, pl. 3, fig. 11.

2004 Frondina permica Sellier de Civrieux and Dessauvagie; Jenny et al., pl. 8, fig. 17.

2005 Frondina permica Sellier de Civrieux and Dessauvagie; Groves et al., p. 27, fig. 21.12, 21.20, figs. 22.6-22.13, 22.14 (with synonymy).

2005 Frondina permica Sellier de Civrieux and Dessauvagie; Hughes, pl. 2, figs. 9, 17-18.

v. 2005 Frondina permica Sellier de Civrieux and Dessauvagie; Mohtat-Aghai and Vachard, pl. 2, figs. 22-25.

v. 2006 Frondina permica Sellier de Civrieux and Dessauvagie; Insalaco et al., pl. 2, fig. 22.

v. 2007 Frondina permica Sellier de Civrieux and Dessauvagie; Gaillot and Vachard, p. 138-139, pl. 4, fig. 23, pl. 74 , figs. $1-2$, pl. 77 , figs. 16,22 , pl. 83 , fig. 22 , pl. 84 , fig. 23 pl. 91 , fig. 20 (with synonymy).

2009 Frondina permica Sellier de Civrieux and Dessauvagie; Song et al., fig. 11.37-39.

2009 Frondina palmata Sellier de Civrieux and Dessauvagie; Ueno and Tsutsumi, figs. 9.19, 11.31.

?2009 Frondina laxa (Lin, Li and Sun); Nestell et al., pl. 2, figs. 18-19. 
?2009 Frondina cf. F. paraconica (Lin, Li and Sun); Nestell et al., pl. 2, figs. 20-21.

v. 2009 Frondina permica Sellier de Civrieux and Dessauvagie; Mohtat-Aghai et al., pl. 2, figs. 25-26.

?2010 Pseudolangella? sp.; Ueno et al., fig. 5.26 .

? 2011 "Pseudoglandulina"; Song et al., fig. 6.44 .

Description. Test uniseriate with rectilinear axis of development. Chambers horseshoe shaped to semi-ellipsoidal, weakly enveloping to evolute. Wall hyaline but apparently dark. Aperture simple, terminal, central, with two inner oral tongues.

Dimensions. $\mathrm{H}=0.200-0.430 \mathrm{~mm}, \mathrm{w}=0.40-0.090$ $\mathrm{mm}, \mathrm{w} / \mathrm{H}=0.50-0.60, \mathrm{p}=0.020-0.030 \mathrm{~mm}$, chambers: (2) $4-5, h=0.035-0.060 \mathrm{~mm}, \mathrm{~s}=0.007-0.010$ $\mathrm{mm}$.

Occurrence. Lopingian of Turkey, Greece, Iran (Abadeh, Zagros), ?Yunnan and Cambodgia; and according to Groves et al. (2005, p. 27): northern Italy, Alborz, Koryak upland, NW Caucasus, Armenia, Lamayuru Block (Himalaya, Japan and Indochina). Midian-Djulfian of Maku (P31, P34, P37, P49, P51 and P54).

Genus ICHTHYOFRONDINA Vachard in Vachard and Ferrière, 1991 emend. Gaillot and Vachard, 2007

Type species. Ichthyolaria latilimbata Sellier de Civrieux and Dessauvagie, 1965.

Synonyms. Frondina Sellier de Civrieux and Dessauvagie, 1965 (part.); Lingulina (part.), Pseudoglandulina (part.); Ichthyolaria (part.); Frondicularia (part.).

Description. Test uniseriate. Chambers palmate, strongly enveloping, rarely evolute. Wall hyaline but apparently dark. Aperture simple, terminal, central, with two inner oral tongues, or absent.

Composition. See Gaillot and Vachard (2007, p. 139).

Occurrence. Late Midian-Changhsinghian, Palaeo- and Neo-Tethyan (Turkey, northern Caucasus, Armenia, Iran, South China, Thailand, New Zealand).

Ichthyofrondina palmata (Wang, 1974)

Figure 19.36-38

1974 Ichthyolaria palmata Wang, p. 287, pl. 149, fig. 11.

? 1995 Ichtyolaria latilimbata de Civrieux and Dessauvagie; Partoazar, pl. 1(1), fig. 12, pl. 2(2), fig. 4, pl. 3(1), fig. 13, pl. $3(2)$, fig. 7.
1997

2005

Lunucammina palmata

(Wang);

Kobayashi, pl. 3, figs. 13-14.

Ichthyofrondina palmata (Wang);

Groves et al., p. 25, fig. 22.1-22.5 (with

synonymy).

2006b Frondina palmata Wang; Kobayashi, fig. 9.4-9.8.

v. 2007 Ichthyofrondina palmata (Wang); Gaillot and Vachard, p. 139-140, pl. 10, fig. 11, pl. 73, fig. 6 (with synonymy).

2009 Ichthyofrondina palmata (Wang); Song et al., fig. 11.33-36.

2009 Ichthyofrondina palmata (Wang); Ueno and Tsutsumi, fig. 9.17.

2010 Ichthyofrondina palmata (Wang); Angiolini et al., fig. 4.24.

?2010 Ichthyofrondina sp.; Ueno et al., fig. 5.31 .

? 2011 "Ichthyofrondina"; Song et al., fig. 6.31.

Description. Test uniseriate with rectilinear axis of development. Chambers palmate, strongly enveloping. Wall hyaline but apparently dark. Aperture simple, terminal, central.

Dimensions. Very small test with palmate chambers. $\mathrm{H}=0.120-0.150 \mathrm{~mm}$; $\mathrm{w}=0.060-0.090 \mathrm{~mm}$; $\mathrm{w} / \mathrm{H}=0.60-0.75 ; \mathrm{p}=0.010-0.020 \mathrm{~mm}$; chambers: $5-6 ; \mathrm{h}=0.030-0.060 \mathrm{~mm} ; \mathrm{s}=0.007-0.010 \mathrm{~mm}$.

Occurrence. Lopingian of South China, Armenia, Turkey and Zagros (Gaillot and Vachard, 2007). Lopingian of Yunnan (Ueno et al., 2010). MidianDjulfian of Maku (P34, P39, P49, P50 and P51).

Family COLANIELLIDAE Fursenko in RauzerChernousova and Fursenko, 1959

Genus COLANIELLA Likharev, 1939

Type species. Pyramis parva Colani, 1924.

Occurrence. Late Midian-Dorashamian (Kotlyar et al., 1989; Jenny-Deshusses and Baud, 1989). Late Djulfian-Dorashamian (Vachard et al., 2002). Limited to the Changhsingian of South China (Lin et al., 1990, p. 83).

Colaniella aff. minuta Okimura, 1988

Figure 19.25

To compare to:

1988 Colaniella minuta Okimura, p. 719, 721, figs. 6.1-6.4.

v. 2005 Colaniella cf. minuta Okimura; Vachard et al., p. 173, pl. 6.6-6.7.

v. 2007 Colaniella aff. minuta Okimura; Vachard et al., p. 142, pl. 73, figs. 1213, pl. 74, figs. 9-10, 18, pl. 75, fig. 6, 
pl. 78 , fig. 11, pl. 83, figs. 16-17, 30, pl. 87 , fig. 12, pl. 91 , fig. 5 (with synonymy).

Remark. Only one specimen, but totally similar to the taxon described by Gaillot and Vachard (2007, p. 142) which constitutes probably a new species useful for the biozonation of Pakistan, NW Iran, Armenia and Saudi Arabia.

Occurrence. Very rare in Maku (P41).

Superfamily NODOSARIOIDEA Ehrenberg, 1838 nom. translat. Loeblich and Tappan, 1961

Famly NODOSARIIDAE Ehrenberg, 1838 Genus LINGULINA d'Orbigny, 1826

Type species. Lingulina carinata d'Orbigny, 1826. Lingulina cf. imaginaria Pronina, 1999

Figure 19.16

1999 Lingulina imaginaria Pronina, p. 12, pl. fig. 19.

Description. $\mathrm{H}=0.200-0.250 \mathrm{~mm} ; \mathrm{w}=0.105-$ $0.120 \mathrm{~mm} ; \mathrm{H} / \mathrm{w}=1.50-1.85$; number of whorls: 5 ; proloculus diameter: $0.020-0.030 \mathrm{~mm} ; \mathrm{h}=0.350$ $0.400 \mathrm{~mm}$.

Remarks. Our specimens are similar in size to $L$. imaginaria, although more compressed and with chevron-shaped rather than horseshoe-shaped chambers. The dating differs also since L. imaginaria is Dorashamian (i.e., latest Permian) in age.

Occurrence. Early Murgabian of Maku (P3).

\section{Family PACHYPHLOIIDAE Loeblich and Tappan,} 1984

Description. Test uniseriate, thick walled, with radiate aperture. Frontal and sagittal axial sections are very different in aspect. Sagittal axial sections show enveloping curved septa, whereas frontal axial sections show the thickened walls. Aperture stellate.

Occurrence. Sakmarian to Jurassic. The FAD of Pachyphloia is discussed: probably Middle Permian according to Pinard and Mamet (1998), late Early Permian: Chihsian (Lin et al., 1990) or Artinskian (Groves, 2000), may be early Early Permian (Sakmarian) (Vachard and Krainer, 2001). The LAD is Dorashamian (e.g., Lin et al., 1990; Pronina-Nestell and Nestell, 2001; Wang and Ueno, 2003; Shang et al., 2003).

\section{Genus PACHYPHLOIA Lange, 1925}

Type species. Pachyphloia ovata Lange, 1925 (see Loeblich and Tappan, 1987, non Sellier de Civrieux and Dessauvagie, 1965).

Occurrence. FAD in the Sakmarian; LAD: latest Permian. Acme and specific diversification: MidianLopingian in Hazro (Turkey) and Zagros (Iran).
Pachyphloia ex gr. ovata Lange, 1925

Figure 19.13, 19.26

1925 Pachyphloia ovata Lange, p. 231, pl. 1, fig. 24a-b.

v. 1993a Pachyphloia ovata Lange; Vachard et al., pl. 7, fig. 13.

p. 1997 Pachyphloia ovata Lange; Kobayashi, pl. 3, figs. 615, 20.27 (with synonymy).

2006b Frondina palmata Wang; Kobayashi, fig. 9.25-9.31

v. 2007 Pachyphloia ovata Lange; Gaillot and Vachard, p. 143-144, pl. 72, figs. 5, 23, pl. 73, figs. 4, 8 (with synonymy).

2009 Pachyphloia ovata Lange; Song et al., fig. 10.28-30.

2012 Pachyphloia ovata Lange; Wignall et al., fig. 10G.

Description. This species is the smallest Pachyphloia; it is subelliptical in axial section and fanshaped in transverse section. This species is relatively tolerant and well adapted; hence, it occupies all the occurrence zone of this genus. $\mathrm{H}=0.180$ $0.300 \mathrm{~mm} ; \mathrm{w}=0.120-0.200 \mathrm{~mm} ; \mathrm{w} / \mathrm{H}=0.75-0.80$; $\mathrm{p}=0.020-0.040 \mathrm{~mm} ; \mathrm{n}$ chambers: $4-6 ; \mathrm{h}=0.010$ $0.020 \mathrm{~mm}$.

Occurrence. Midian-Lopingian: Taurus, Zagros, Azarbaijan, Greece, Armenia, Italy, NW Caucasus, Pakistan, Indonesia, South China, Indochina, Japan, New Zealand. Murgabian- Djulfian in Maku (P9, P10, P14?, P17, P19, P32, P35, P35(2), P37, P40, P41, P52, P54 and P55).

Pachyphloia cf. iranica Bozorgnia, 1973

Figure 19.17

To compare to:

1973 Pachyphloia iranica Bozorgnia, p. 155156, pl. 37, figs. 1-6.

1980 Pachyphloia iranica Bozorgnia; Lys et al., p. 88-89, pl. 4 (non pl. 4, fig. 10: Pachyphloia iranica colcheni $\mathrm{n}$. subsp. $=\mathrm{a}$ colaniellid and probably a true Colaniella).

non 2005 Pachyphloia iranica Bozorgnia; Hughes, pl. 3, figs. 11, 22, pl. 4, figs 2, 4-5 (other nodosariates).

Description. Rare sections of this large forms with many chambers.

Occurrence. Murgabian-Djulfian of Alborz, Taurus, Ladakh (Himalaya), and New Zealand. Midian of Maku (P41). 


\begin{tabular}{|c|c|c|c|c|}
\hline REGIONS & TURKEY & IRAN & $\begin{array}{c}\text { AFGHANISTA } \\
\mathbf{N}\end{array}$ & PAMIR \\
\hline PERIHERCYNIAN & PONTIDES & $\begin{array}{c}\text { MASHHAD } \\
\text { area }\end{array}$ & $\begin{array}{c}\text { HINDU } \\
\text { KUSH }\end{array}$ & $\begin{array}{c}\text { NORTHER } \\
\mathbf{N} \\
\text { PAMIR }\end{array}$ \\
\hline $\begin{array}{c}\text { CIMMERIAN } \\
(= \\
\text { EXTRAGONDWANA } \\
\mathbf{N})\end{array}$ & $\begin{array}{c}\text { SARAKAYA } \\
\text { block }\end{array}$ & ALBORZ & $\begin{array}{l}\text { BAND-E } \\
\text { BAYAN }\end{array}$ & $\begin{array}{l}\text { RUSH } \\
\text { KOL } \\
\text { ZONE }\end{array}$ \\
\hline intermediary & $?$ & $?$ & $\begin{array}{c}\text { CENTRAL } \\
\text { MOUNTAINS } \\
\text { of } \\
\text { AFGHANISTAN }\end{array}$ & $\begin{array}{l}\text { S.E. } \\
\text { PAMIR }\end{array}$ \\
\hline PERIGONDWANAN & $\begin{array}{c}\text { TAURUS } \\
\stackrel{+}{+}^{-} \\
\text {KARABURU } \\
\text { N }+ \\
\text { CHIOS } \\
\end{array}$ & $\begin{array}{c}\text { NW IRAN (this } \\
\text { study), } \\
\text { ABADEH area, } \\
\text { ZAGROS }\end{array}$ & KABUL & $?$ \\
\hline GONDWANAN & ARABIA & ARABIA & INDIA & INDIA \\
\hline
\end{tabular}

FIGURE 20. Attempt of palaeogeographical correlations between the terranes separated by the Tethys ocean during the Permian (after Vachard, 1980; 1996; Vachard and Montenat, 1981, 1996; and D. Vachard (unpublished data)).

\section{DISCUSSION AND CONCLUSIONS}

The foraminiferal microfaunas of NW Iran are generally well-known and well-studied. Nevertheless, the section of Maku is permitted to find some new taxa and to accurately define the range of some other ones. No endemic forms have been encountered and the smaller foraminiferal microfauna is similar to that of the other regions of Iran (Bozorgnia, 1983; Partoazar, 1995; Gaillot, 2006; Insalaco et al., 2006; Gaillot and Vachard, 2007; Mohtat-Aghai et al., 2009; Kolodka et al., 2012; Parvizi et al., 2013; Filimonova, 2013). The fusulinids remain rare as in all the Palaeo-Tethys and Neo-Tethys western branches, compared to the central (e.g., Pamir) and western (e.g., South China) branches of these oceans. Some narrow similarities of the NW Iran microfauna with that of South China are confirmed in this study. Because of the foraminiferal assemblages, a palaeobio- and palaeogeographical location of NW Iran in the Perigondwanan Realm is suggested, contrary to many current reconstructions, which emplaced this area in the Cimmerian Continent located between Palaeo- and Neo-Tethys. Similarly, Armenia is a Perigondwanan territory because it contains Late
Permian smaller foraminifer "Angelina" Altiner, 1988 discovered by Pronina and Gubenko (1990). This genus was first defined in the Taurus Mountains in southern Turkey, which are unquestionably a part of the Perigondwanan border, and because the radiation centre of "Angelina" occurs in this area with the following lineage: (a) Lazarus effect of Pseudovidalina in the Murgabian-Midian (Zaninetti et al., 1981; Güvenç, 1988; Pronina and Gubenko, 1990); (b) primitive "Angelina" during the Midian time (Pronina and Gubenko, 1990); (c) advanced "Angelina" during the Late Permian subsystem (Güvenç, 1988). "Angelina" must be renamed because it is preoccupied by a Cambrian trilobite; it was synonymized by Pinard and Mamet (1998) with Xingshandiscus but this homeomorphous genus seems to be different due to its (primitive) bilayered wall. "Angelina" might be present in NW Iran and Zagros but it has not been yet discovered in both areas. As another explanation, "Angelina" can be restricted to Armenia and Taurus and constitutes a subprovince of the Perigondwanan Realm, probably isolated by sea currents or some continental barriers.

As in Zagros and Taurus, a primitive species of Paradagmarita, P. sp., has been found. Similarly, 


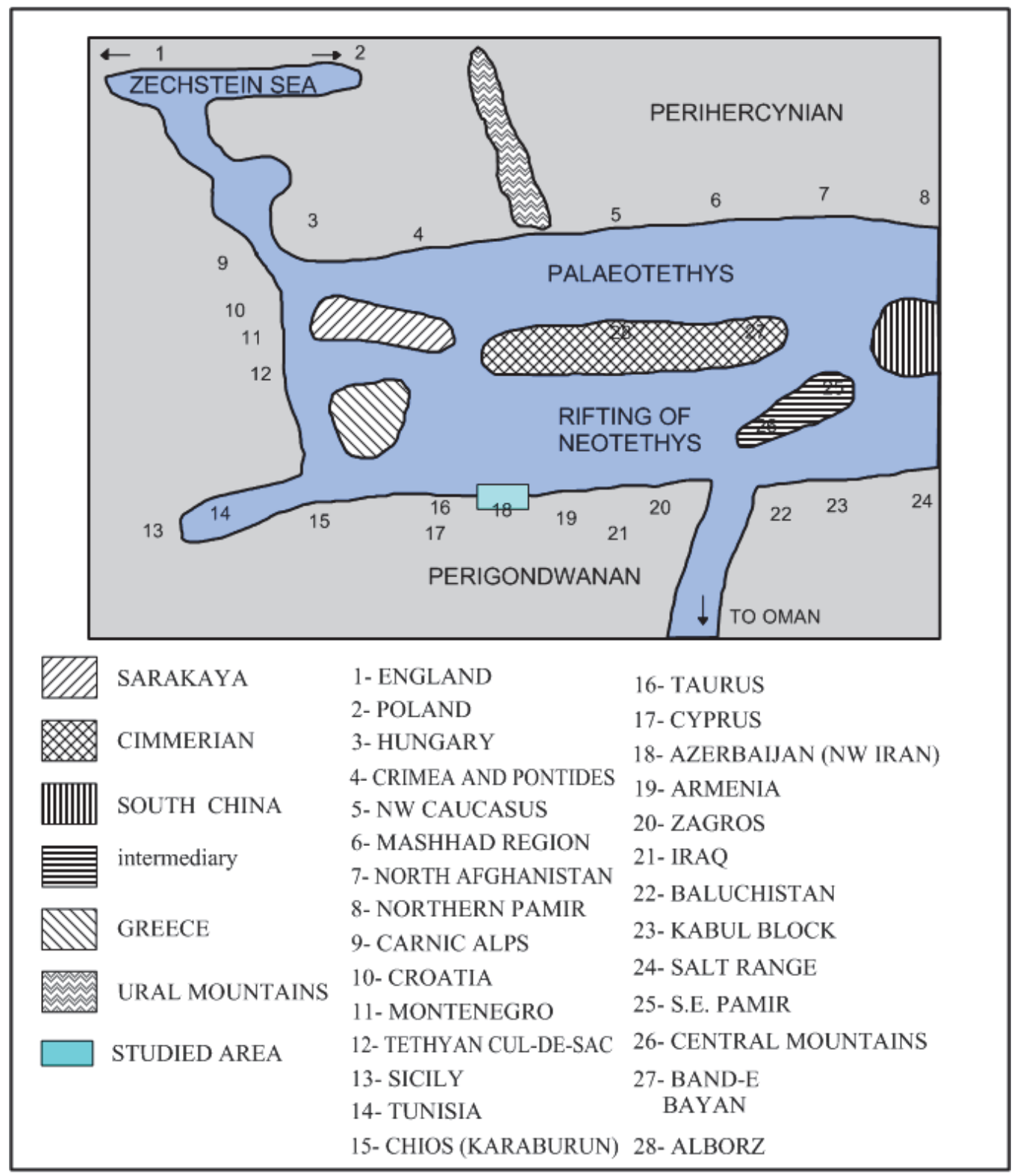

FIGURE 21. Proposed palaeomap of the Tethyan regions from western Europe to central Asia (according to Théry et al., 2007 modified; and D. Vachard (unpublished data)).

Frondina and Ichthyofrondina are common in the three regions (Zagros, NW Iran, Taurus), as well in Armenia.

Although the NW Caucasus belongs to the northern border of the Palaeo-Tethys, it is closely related with South China during the late Changhsingian, but its algal and foraminiferal populations differ sensibly from those of Armenia and NW Iranian Azerbaijan. These latter have been generally correlated with southern Crimea and Alborz Mountains as part of Cimmerian blocks (e.g., Wignall and Twichett, 2002; Théry et al., 2007). Bükk
Mountains and Greece are poorly constrained but seem to belong to one or two independent microplates.

The Perigondwanan Domain is considered here as it was interpreted by Vachard et al. (2005). It extends to the Tebaga in Tunisia. The eastern border of the Palaeo-Tethys-Neo-Tethys confluence is constituted by Italy and ex-Yugoslavia. Within the Peri-Hercynian Domain exist two confined seas: the Zechstein Sea and the Bellerophon Sea (e.g., Théry et al., 2007, fig. 8). This palaeogeography (Figures 20-21) was consistent with the 
distribution of the Permian markers first emphasized by Sengör et al. (1988), namely Eopolydiexodina, Shanita, Palaeofusulina and Colaniella, but is not consistent with some of our markers: e.g., Sumatrina, Glomomidiella transitional to Baisalina or to Neodiscopsis, Okimuraites (= Brunsispirella), primitive Paradagmarita and Colaniella aff. minuta.

As in Armenia, in Iranian Azerbaijan and especially in the Kuh-e Ali Bashi area, the Dorashamian (= Changhsingian) is represented by red nodular limestone rich in ammonoids and conodonts but poor in foraminifers (Altiner et al., 1980; Baud, 2008; Leda et al., 2013). That confirms the geographical affinities of Armenia and Azerbaijan, and their assignment to the Perigondwanan border.

If the Neo-Tethys, as an oceanic spreading area, opened in the Middle Permian (see Sharland et al., 2001), the Cimmerian Continent sensu lato (more exactly the Extragondwanan Realm of Vachard, 1980) was individualized as an island or archipelago since at least the late Viséan (Vachard, 1980; Okuyucu et al., 2013) with the following constitutents: Sarakaya Terrane in Turkey, Alborz in Iran and Band-e Bayan in Afghanistan (Figures 2021).

As indicated by Théry et al. (2007), both Palaeo- and Neo-Tethyan branches during the Middle-Late Permian belong to the same tropical/subtropical climatic zone, and the foraminiferal and algal assemblages do not permit to individualize each branch accurately. Nevertheless, due to some biomarkers, NW Iran, Armenia, Zagros and Abadeh appear geographically related, whereas they appear not connected with the Alborz (Figure 21).

\section{ACKNOWLEDGMENTS}

Thanks to Geological Survey Management of NW Iran, Tabriz (M,N. Oskuei, M. Faridi, A. Alavi and $P$. Sahbari) for helpful advice and guidance. Thanks also to V. Hayart, S. Clausen, T. Vachard, and L. Devaere (Villeneuve d'Ascq, France) for their technical help.

\section{REFERENCES}

Aghanabati, A. 2006. Geology of Iran. Geological Survey of Iran.

Akopian, V.T. 1974. Atlas of the fossil fauna from Armenia SSR. Akademiya Nauk Armenia SSR, Institut Geologicheskykh Nauk, Erevan. (In Russian)
Alavi Naini, M. and Bolourchi, H. 1973. Geology of the Makou area. Geological Survey of Iran, Report No. Al.

Alipour, Z., Hosseini-Nezhad, S.M., Vachard, D., and Rashidi, K. 2013. Biostratigraphy and description of smaller foraminifers of Dorud Group (uppermost Gzhelian-lower Sakmarian) in Tang-e Shamshirbor section, eastern Alborz, Iran. Geological Journal, 48 (4):385-402.

Altiner, D. 1978. Trois nouvelles espèces du genre Hemigordius (Foraminifère) du Permien supérieur de Turquie (Taurus oriental). Notes du Laboratoire de Paléontologie de l'Université de Genève, 2:27-31.

Altiner, D. 1981. Recherches stratigraphiques et micropaléontologiques dans le Taurus Oriental au NW de Pinarbasi (Turquie). Unpublished PhD Thesis, Université de Genève, $\mathrm{n}^{\circ} 2005$.

Altiner, D. 1984. Upper Permian foraminiferal biostratigraphy in some localities of the Taurus Belt. International Symposium of the Geology of the Taurus Belt 1983, Reprint M.T.A.: 255-268.

Altiner, D. 1988. Pseudovidalinidae n. fam. and Angelina n. gen. from the Upper Permian of South and Southeast Turkey. Revue de Paléobiologie, special volume $N^{\circ}$ 2, Benthos'86 Genève:25-36.

Altiner, D. 1997. Origin, morphologic variation and evolution of Dagmaritin-type Biseriamminid stock in the late Permian, p. 1-4. In Ross, C.A., Ross, J.R.P., and Brenckle, P.L. (eds.), Late Paleozoic foraminifera, their biostratigraphy, evolution and paleoecology, and the Mid-Carboniferous boundary. Cushman Foundation for Foraminiferal Research, Special Publication 36:1-4.

Altiner, D. 1999. Sengoerina argandi, n. gen., n. sp., and its position in the evolution of late Permian biseriamminid foraminifers. Micropaleontology, 45:215-220.

Altiner, D. and Brönnimann, P. 1980. Louisettita elegantissima, n. gen. n. sp., un nouveau foraminifère du Permien supérieur du Taurus oriental (Turquie). Notes du Laboratoire de Paléontologie de l'Université de Genève, 6:39-43.

Altiner, D. and Özkan Altiner, S. 1998. Baudiella stampflii n. gen. n. sp., and its position in the evolution of Late Permian ozawainellid fusulines. Revue de Paléobiologie, 17:163-175.

Altiner, D. and Özkan Altiner, S. 2010. Danielita gailloti n. gen., n. sp., within the evolutionary framework of Middle-Late Permian dagmaritins. Turkish Journal of Earth Sciences, 19:497-512.

Altiner, D. and Savini, R. 1997. New species of Syzrania from the Amazonas and Solimöes basins (North Brazil): remarks on the generic and suprageneric position of syzraniid foraminifers. Revue de Paléobiologie, 16 (1):7-20.

Altiner, D., Baud, A., Guex, J., and Stampfli, G. 1980. La limite Permien-Trias dans quelques localités du Moyen-Orient: recherches stratigraphiques et micropaléontologiques. Rivista Italiana di Paleontologia, 85 (1979):683-714. 
Angiolini, L. and Rettori, R. 1994. Chitralina undulata gen. n. sp. n. (Foraminiferida) from the Late Permian of Karakorum (Pakistan). Rivista Italiana di Paleontologia e Stratigrafia, 100:477-492.

Angiolini, L., Checconi, A., Gaetani, M., and Rettori, R. 2010. The latest Permian mass extinction in the Alborz Mountains (North Iran). Geological Journal, 45:216-229.

Armstrong, A.K. and Mamet, B. 1977. Carboniferous microfacies, microfossils, and corals, Lisburne Group, Arctic Alaska. U.S. Geological Survey Professional Paper, 849:1-144.

Arnaud-Vanneau, A. 1980. Micropaléontologie, paléoécologie et sédimentologie d'une plate-forme carbonatée de la marge passive de la Téthys: l'Urgonien du Vercors septentrional et de la Chartreuse (Alpes occidentales). Géologie Alpine, Mémoire 11:269-874.

Assereto, R. 1963. The Paleozoic Formations in Central Elburz (Iran). Rivista Italiana di Paleontologia, 69:503-543.

Baghbani, D. 1993. The Permian sequence in the Abadeh region, Central Iran. Occasional Publications ESRI, new series 9 A-B, part II:7-22.

Baryshnikov, V.V., Zolotova, V.P., and Kosheleva, V.F. 1982. Novye vidy foraminifer artinskogo yarusa permskogo Priuralya [New species of foraminifers from Artinskian stage of the Pre-Ural]. Akademiya Nauk SSSR, Uralskii Nauchnyi Tsentr, Institut Geologii i Geokhimii, Preprint:1-54. (In Russian)

Baud, A. 2008. Correlation of Upper Permian localities in the Kuh-e-Ali Bashi area, NW Iran: old collections and new data. Permophiles, 52:6-11.

Baud, A., Magaritz, M., and Holser, W.T. 1989. PermianTriassic of the Tethys: carbon isotope studies. Geologische Rundschau, 78:649-677.

Baud, A., Jenny, C., Papanikolaou, D., Sideris, Ch., and Stampfli, G. 1991. New observations on Permian stratigraphy in Greece and geodynamic interpretation. Bulletin of the Geological Society of Greece, 25:187-206.

Berczi-Makk, A. 1978. Tengeri felsöperm üledékek Budapesttöl DK-re a Sári-2. Sz. Szénhidrogénkutató fúrásban Földtani Közlöny. Bulletin of the Hungarian Geological Society, 108:313-327.

Berczi-Makk, A., Csontos, L., and Pelikán, P. 1995. Data on the Upper Permian foraminifer fauna of the Nagyvisnyó Limestone formation from borehole Mályinka-8 (Northern Hungary). Acta Geologica Hungarica, 38:185-250.

Bolourchi, M.H. 1979. Text of the Kabudar Ahang Quadrangle Map, 1:250000. Geological Survey of Iran, Report No. D5.

Bozorgnia, F. 1973. Paleozoic foraminiferal biostratigraphy of central and east Alborz Mountains, Iran. National Iranian Oil Company, Geological Laboratories, Publication no. 4:1-185.
Brady, H.B. 1873. On Archaediscus Karreri a new type of Carboniferous foraminifera. Annals and Magazine of Natural History, 4 (12):286-290.

Brady, H.B. 1876. A monograph of Carboniferous and Permian foraminifera (the genus Fusulina excepted). Palaeontographical Society, 30:1-166.

Brady, H.B. 1884. Report of the foraminifera dredged by H.M.S. Challenger during the years 1873-1876. Reports on the Scientific Results of the Exploratory Voyage of the H.M.S. Challenger, Zoology, 9:1-814.

Brenckle, P.L. 2005. A compendium of Upper DevonianCarboniferous type foraminifers from the former Soviet Union. Cushman Foundation for Foraminiferal Research, special publication 38:1-153.

Bykova, E.V. and Polenova, E.N. 1955. Foraminifery, radiolarii $i$ ostrakody Devona Volgo-Uralskoi oblasti [Foraminifers and radiolaria from the Volga-Ural area and the central Devonian Field and their stratigraphical importance]. Trudy VNIGRI, 87:1-141. (In Russian; French translation, CEDP $n^{\circ} 1603$, BRGM: 1154)

Canuti, P., Marcucci, M., and Pirini Radrizzani, C. 1970. Microfacies e microfaune nelle formazioni paleozoiche dell'anticlinale di Hazro (Anatolia sud-orientale, Turchia). Bolletino Societá Geologica Italiana, 89:2140.

Cavalier-Smith, T. 2002. The phagotrophic origin of eukaryotes and phylogenetic classification of Protozoa. International Journal of Systematic and Evolutionary Microbiology, 52:297-354.

Cavalier-Smith, T. 2003. Protists phylogeny and the highlevel classification of Protozoa. European Journal of Protistology, 39:338-348.

Chang, Xiaolin, Shi, He, Li, Kui, and Hu, Fang 2012. Biostratigraphy and chronostratigraphic boundaries of the Permian at the Ganzhai section, Pingtang, Guizhou Province. Acta Micropaleontologica Sinica, 29:391-401. (In Chinese with English summary)

Chediya, I.O., Bogolovskaya, M.F., Davydov, V.I., and Dmitriev, V.Yu. 1986. Fuzulinidy $i$ ammonoidei v stratotipe kubergandinskogo yarusa (Yugo-vostochnyy Pamir) [Fusulinids and ammonoids from the Kubergandian stratotype (SE Pamir)]. Akademiya Nauk SSSR, Ezhegodnik Vsesoyuznogo Paleontologischeskogo Obshchestva, 29:28-53. (In Russian)

Chen, S. 1956. The Fusulinidae of South China. Palaeontologica Sinica, 140, part ii, ser. b, 6:1-71.

Chernysheva, N.E. 1941. Novyi rod foraminifer iz turneiskikh otlozhenii Urala [New genus of foraminifera from the Tournaisian deposits of the Urals]. Doklady Akademiya Nauk SSSR, 32:69-70. (In Russian)

Chernysheva, N.E. 1948. Nekotororye novye vidyi foraminifer iz vizeyskogo yarusa Makarovskogo raiona (Yuzhnyi Ural) [Some new species of Viséan foraminifers from the Makarov District (southern Urals)]. Akademiya Nauk SSSR, Trudy Instituta Geologicheskikh Nauk, 62, geologiskaya seriya, 19:246-250. (In Russian) 
China, W.E. 1965. Opinion 724. Endothyra bowmani Phillips (1846) (Foraminifera): valided under the plenary powers. Bulletin of Zoological Nomenclature, 22:37-39.

Ciarapica, G., Cirilli, S., Martini, R., and Zaninetti, L. 1986. Une microfaune à petits foraminifères d'âge permien remaniée dans le Trias moyen de l'Apennin méridional (Formation du Monte Facito, Lucanie occidentale); description de Crescentia vertebralis $\mathrm{n}$. gen. n. sp. Revue de Paléobiologie, 5:207-215.

Ciarapica, G., Cirilli, S., Passeri, L., Trincati, E., and Zaninetti, L. 1987. "Anidriti di Búrano" et "Formation du Monte Cetona" (nouvelle formation), biostratigraphie des deux séries-types du Trias supérieur dans l'Apennin septentrional. Revue de Paléobiologie, 6:341-409.

Ciry, R. 1948. Un nouveau Fusulinidé permien: Dunbarula matthieui. Bulletin Scientifique de Bourgogne, 11 (1946-47):103-110.

Colani, M. 1924. Nouvelle contribution à l'étude des fusulinidés de l'Extrême-Orient. Mémoires du Service géologique de l'Indochine, 11:9-199.

Conil, R., Groessens, E., and Lys, M. 1977. Etude micropaléontologique de la tranchée d'Yves-Gomezée ( $\mathrm{Tn}$ $3 c-V 1-V 2$, Belgique). Bulletin de la Société belge de Géologie, 82 (1973):201-239.

Crespin, I. 1958. Permian Foraminifera of Australia. Commonwealth of Australia, Department of National Development, Bureau of Mineral Resources, Geology and Geophysics, 48:1-207.

Cummings, R.H. 1955. Nodosinella Brady, 1876 and associated Upper Paleozoic genera. Micropaleontology, 1:221-238.

Cushman, J.A. and Waters, J.A. 1928. Some Foraminifera from the Pennsylvanian and Permian of Texas. Contributions from the Cushman Laboratory for Foraminiferal Research, 4:31-55.

Cushman, J.A. and Waters, J.A. 1930. Foraminifera of the Cisco Group. Bulletin University of Texas, 3019:22-81.

Davydov, V.I. 2011. Taxonomy, nomenclature, and evolution of the early schubertellid fusulinids. Acta Palaeontologica Polonica, 56 (1):181-194.

Davydov, V.I. and Arefifard, S. 2007. Permian fusulinid fauna of Peri-Gondwanan affinity from the Kalmard region, east-Central Iran and its significance for tectonics and paleogeography. Palaeontologia Electronica, 10 (2), 10A:1-40.

Davydov, V.I. and Arefifard, S. 2013. Middle Permian (Guadalupian) fusulinid taxonomy and biostratigraphy of the mid-latitude Dalan Basin, Zagros, Iran and their applications in paleoclimate dynamics and paleogeography. GeoArabia, 18 (2):17-62.

Davydov, V.I., Belasky, P., and Karavayeva, N.I. 1996. Permian fusulinids from the Koryak terrane, northeastern Russia, and their paleobiogeographic affinity. Journal of Foraminiferal Research, 26:213-243.
Davydov, V.I., Krainer, K., and Chernykh, V. 2013. Fusulinid biostratigraphy of the Lower Permian Zweikofel Formation (Rattendorf Group; Carnic Alps, Austria) and Lower Permian Tethyan chronostratigraphy. Geological Journal, 48:57-100.

Delage, Y. and Hérouard, E. 1896. Traité de Zoologie Concrète, volume 1: la cellule et les Protozoaires. Paris, Schleicher Frères.

Deleau, P. and Marie, P. 1961. Les Fusulinidés du Westphalien $\mathrm{C}$ du bassin d'Abadla et quelques autres foraminifères du Carbonifère algérien. Publications Service Carte Géologique Algérie, 25:45-160.

Delvolvé, J.J., Perret, M.F., and Vachard, D. 1987. Découverte du Kachirien (Moscovien inférieur) à fusulines et algues dans le massif de Cinco Villas (Pyrénées basques, Espagne). Geobios, 20 (4): 541548.

Deprat, J. 1912. Sur deux genres nouveaux de Fusulinidés de l'Asie orientale, intéressants au point de vue phylogénique. Comptes Rendus de l'Académie des Sciences de Paris, 154:1548-1550.

Deprat, J. 1913. Les Fusulinides des calcaires carbonifériens et permiens du Tonkin, du Laos et du NordAnnam. Mémoire du Service Géologique de I'Indochine, 2 (1), Etude des Fusulinides de Chine et d'Indochine et classification des calcaires à fusulines II. Mémoire:1-74.

Derville, H. 1952. A propos de Calcisphères (rectification). Comptes Rendus Sommaires de la Société Géologique de France, 6:236-237.

d'Orbigny, A. 1826. Tableau méthodique de la classe des Céphalopodes. Annales des Sciences Naturelles, 7:245-314.

Dunbar, C.O. and Condra, G.E. 1927. The Fusulinidae of the Pennsylvanian system in Nebraska. Nebraska Geological Survey, 2nd series, Bulletin 2:1-135.

Dunbar, C.O. and Henbest, L.G. 1930. The fusulinid genera Fusulina, Fusulinella and Wedekindella. American Journal of Science, 5th series, 20:357-364.

Ehrenberg, C.G. 1838. Über dem blossen Auge unsichtbare Kalkthierchen und Kieselthierchen als Hauptbestandtheile der Kreidgebirge. Bericht über die zu Bekanntmachung geeigneten Verhandlungen der königlischen preussischen Akademie der Wissenschaften zu Berlin, 1838 (3):192-200.

Elliott, G.F. 1958. Fossil microproblematica from the Middle East. Micropaleontology, 4:419-428.

Endo, R. and Kanuma, M. 1954. Stratigraphical and paleontological studies of the Later Paleozoic calcareous algae in Japan, VII. Geology of the Mino Mountain Land and southern part of Hida Plateau, with description of the algal remains found in those districts. Science Reports of the Saitama University, B, 1:177-205.

Filimonova, T.V. 2010. Smaller foraminifers of the Lower Permian from Western Tethys. Stratigraphy and Geological Correlation, 18:687-811. 
Filimonova, T.V. 2013. Smaller foraminifers from the Permian of Central Iran. Stratigraphy and Geological Correlation, 21:18-35.

Flügel, E. 2004. Microfacies of Carbonate Rocks, Analysis, Interpretation and Application. Springer Publisher.

Fontaine, H. and Nguyen Duc Tien 1989. Etude morphologique de Rectostipulina quadrata JennyDeshusses (Foraminifère du Permien supérieur) après sa découverte en Thaïlande. Revue de Micropaléontologie, 32:118-125.

Fontaine, H., Bin Aman, I., Khoo, H.P., Nguyen, D.T., and Vachard, D. 1992. The Neoschwagerina-Zone to Palaeofusulina-Zone interval (= upper half of the Permian) and the Permian-Triassic boundary in Malaysia. Geological Survey of Malaysia - Palaeontology of Malaysia, 1:1-100.

Fontaine, H., Suteethorn, V., and Vachard, D. 1993. Carboniferous and Permian limestones in Sop Pong area: unexpected lithology and fossils. International Symposium Biostratigraphy of mainland Southeast Asia: facies and paleontology, 2:319-336.

Fontaine, H., Bin Amnan, I., Khoo, H.P., Nguyen, D.T. and Vachard, D. 1994. The Neoschwagerina and Yabeina-Lepidolina zones in Peninsular Malaysia, and Dzhulfian and Dorashamian in Peninsular Malaysia, the transition to the Triassic. Geological Survey of Malaysia, Geological Papers, 4:1-175.

Fursenko, A.V. 1958. Osnovnye etapy razvitiya faun foraminifer $v$ geologicheskom prohlom [Fundamental stages of development of foraminiferal fauna in the geological past]. Trudy Instituta Geologicheskikh Nauk, Akademiya Nauk Beloruskoi SSR, 1:10-29. (In Russian)

Gaillot, J. 2006. The Late Permian-Early Triassic Khuff Formation in the Middle-East, sequence biostratigraphy and palaeoenvironments by means of calcareous algae and foraminifers. Unpublished PhD., University of Lille 1.

Gaillot, J. and Vachard, D. 2007. The Khuff Formation (Middle East) and time-equivalents in Turkey and South China: biostratigraphy from Capitanian to Changhsingian times (Permian), new foraminiferal taxa, and palaeogeographical implications. Coloquios de Paleontología, 57:37-223.

Gaillot, J., Vachard, D., Galfetti T., and Martini, R. 2009. New latest Permian foraminifers from Laren (Guangxi Province, South China). Palaeobiogeographic implications. Géobios, 42:141-168.

Galloway, J.J. 1933. A manual of Foraminifera. James Furman Kemp Memorial Ser. The Principia Press Incorporated, Bloomington, Indiana, Publication $\mathrm{n}^{\circ} 1$.

Geinitz, H.B. and Gutbier, A. 1848. Die Versteinerungen des Zechsteingebirges und Rothliegenden. Arnold, Dresden, Heft 1.
Gerke, A.A. 1959. O novom rode permskikh nodosarividnykh foraminifer $i$ utochnenii kharakteristiki roda Nodosaria [On a new genus of nodosarian-like foraminifer and the specific characteristics of the genus Nodosaria]. Sbornik Statey po Paleontologii i Biostratigrafii, Nauchno-issledovatelskiy Institut Geologii Artiki (NIIGA), 17:41-59. (In Russian)

Glaessner, M.F. 1945. Principles of micropalaeontology. Melbourne University Press.

Glaus, M. 1964. Trias und Oberperm im Zentrische Elburs (Persien). Eclogae Geologicae Helvetiae, 57:497-508.

Granier, B. and Deloffre, R. 1994. Inventaire critique des algues dasycladales fossiles, Ille partie : les algues dasycladales du Permien et du Trias. Revue de Paléobiologie, 14:49-84.

Grant, R.E., Nestell, M.K., Baud, A., and Jenny, C. 1991. Permian stratigraphy of Hydra Island, Greece. Palaios, 6:479-497.

Griffith, J.W. and Henfrey, A. 1875. The Micrographic Dictionary. London, van Voorst, 1, 3rd edition.

Groves, J.R. 1988. Calcareous foraminifers from the Bashkirian stratotype (Middle Carboniferous, South Urals) and their significance for intercontinental correlations and the evolution of the Fusulinidae. Journal of Paleontology, 62:368-399.

Groves, J.R. 1991. Fusulinacean Biostratigraphy of the Marble Falls limestone (Pennsylvanian), western Llano region, central Texas. Journal of Foraminiferal Research, 21:67-95.

Groves, J.R. 1992. Stratigraphic distribution of nonfusulinacean foraminifers in the Marble Falls Limestone (Lower Middle Pennsylvanian), western Llano region, central Texas, p. 145-161. In Sutherland, P.K. and Manger, W.L. (eds.), Recent advances in MiddleCarboniferous biostratigraphy. Oklahoma Geological Survey:145-161.

Groves, J.R. 2000. Suborder Lagenina and other smaller foraminifers from Uppermost Pennsylvanian-Lower Permian rocks of Kansas and Oklahoma. Micropaleontology, 46:285-326.

Groves, J.R. and Boardman, H. 1999. Calcareous smaller foraminifers from the Lower Permian Council Grove Group near Hooser, Kansas. Journal of Foraminiferal Research, 29:243-262.

Groves, J.R., Altiner, D., and Rettori, R. 2005. Extinction, survival, and recovery of Lagenide foraminifers in the Permian-Triassic boundary interval, Central Taurides, Turkey. Paleontological Society Memoir, Journal of Paleontology (supplement):1-38.

Groves, J.R., Rettori, R., Payne, J.L., Boyce, M.D., and Altiner, D. 2007. End-Permian mass extinction of Lagenide foraminifers in the southern Alps (northern Italy). Journal of Paleontology, 81:415-434. 
Grozdilova, L.P. 1956. Miliolidy verkhneartinskikh otlozhenii nizhnei Permi zapadnogo sklona Urala [Miliolids of the upper Artinskian deposits (Lower Permian) of the western slope of the Urals]. Trudy VNIGRI, 98, Microfauna of USSR, 8:521-528. (In Russian)

Grozdilova, L.P. and Glebovskaya, E.M. 1948. Materialy k izucheniyu roda Glomospira $i$ otlozheniyakh Makarovskogo, Krasnokamskogo, Kizelovskogo i Podmoskovnogo raionov [Material of the genus Glomospira in the Viséan deposits from the areas of Makarov, Krasnokam, Kizel and Submoscow]. Akademiya Nauk SSSR, Trudy Instituta Geologicheskikh Nauk, 62, geologicheskaya seriya, 19:145-149. (In Russian)

Gu, Song-zhu, Pei, Jing-cheng, Yang, Feng-qing, and Gao, Yong-qun 2002. Smaller Foraminifera fauna from the Changxingian of the Sidazhai section, Ziyun County, southern Guizhou Province. Acta Micropaleontologica Sinica, 19:163-169. (In Chinese)

Habeeb, K.H. 1979. SEM study of foraminiferal wall structure in the Lower Carboniferous Limestone. Abstracts of Papers, Ninth International Congress of Carboniferous Stratigraphy and Geology, May 19-26, 1979, University of Illinois at Urbana-Champaign: 8283.

Hance, L., Hou, H.F., and Vachard, D. 2011. Upper Famennian to Visean foraminifers and some carbonate microproblematica from South China, Hunan, Guangxi and Guizhou. Geological Science Press, Beijing, Geological Science Press, Beijing.

Hao, X. and Lin, J. 1982. Foraminifera assemblages of upper Carboniferous Huanglung Formation in Yangchun of Guangdong. Earth Sciences, Journal of Wuhan College of Geology, 3:99-106.

Hauser, M., Vachard, D., Martini, R., Matter, A., Peters, T. and Zaninetti, L. 2000. The Permian sequence reconstructed from reworked carbonate clasts in the Batain Plain (Northeastern Oman). Comptes Rendus de l'Académie des Sciences, 320:273-279.

Henbest, L.G. 1963. Biology, mineralogy, and diagenesis of some typical late Paleozoic sedimentary foraminifera and algal-foraminiferal colonies. Cushman Foundation for Foraminiferal Research, Special Publication, 6:1-44.

Henderson, C.M., Davydov, V.I., and Wardlaw, B.R. (contributors: Gradstein, F.M. and Hammer, O.) 2012. Chapter 24: The Permian Period. In Gradstein, F.M., Ogg, J.G., Schmitz, M.D. and Ogg, G.M., The geologic time scale 2012. Elsevier Publisher.

Ho, J. 1959. Triassic Foraminifera from the Chialingchiang Limestone of South Szechuan. Acta Paleontologica Sinica, 7:387-418. (In Chinese)

Holser, W.T. and Magaritz, M. 1987. Events near the Permian-Triassic boundary. Modern Geology, 11:155-180.
Horacek, M., Richoz, S., Brandner, R., Krystyn, L., and Spötl, C. 2007. Evidence for recurrent changes in Lower Triassic oceanic circulation of the Tethys: the d13C record from marine sections in Iran. Palaeogeography, Palaeoclimatology, Palaeoecology, 252:355-369.

Hsu, Y.C. 1942. On the type species of Chusenella. Bulletin of the Geological Society of China, 22:175-176.

Hughes, G.W. 2005. Saudi Arabian Permo-Triassic biostratigraphy, micropaleontology and palaeoenvironment, p. 91-108. In Powell, A.J. and Riding, J.B. (eds.), Recent Developments in Applied Biostratigraphy. The Micropalaeontological Society, Special Publications:91-108.

Hughes, G.W. 2012. Late Permian to Late Jurassic microproblematica of Saudi Arabia: Possible palaeobiological assignments and roles in the palaeoenvironmental reconstructions. GeoArabia, 18:57-92.

Insalaco, E., Virgone, A., Courme, B., Gaillot, J., Kamali, M., Moallemi, A., Loftpour, M., and Monibi S. 2006. Upper Dalan Member and Kangan Formation between the Zagros Mountains and Offshore Fars, Iran: depositional system, biostratigraphy and stratigraphic architecture. GeoArabia, 11:75-176.

Jenny, C. and Stampfli, G. 2000. Permian palaeogeography of the Tethyan Realm. Permophiles, 37:24-33.

Jenny, C., Izart, A., Baud, A. and Jenny J. 2004. Le Permien de l'île d'Hydra (Grèce), micropaléontologie, sédimentologie et paléoenvironnements. Revue de Paléobiologie, 23:275-312.

Jenny-Deshusses, C. 1983a. Paraglobivalvulina mira Reitlinger (Foraminifère): précisions morphologiques et application stratigraphique dans le Permien supérieur d'Iran. Revue de Micropaléontologie, 25:265-272

Jenny-Deshusses, C. 1983b. Le Permien de l'Elbourz Central et Oriental (Iran) : stratigraphie et micropaléontologie (foraminifères et algues). Unpublished PhD, Université de Genève, no. 2103.

Jenny-Deshusses, C. 1985. Rectostipulina n. gen. (= Stipulina Lys, 1978), un organisme incertae sedis du Permien supérieur de la Téthys moyen-orientale: description morphologique et remarques stratigraphiques. Revue de Paléobiologie, 4:153-158.

Kahler, F. and Kahler, G. 1966. Fossilium Catalogus, I. Animalia: Fusulinida (Foraminiferida). Teil 1, pars 111:1-254; Teil 2, pars 112:255-538; Teil 3, pars 113: 539-870. W. Junk Publishers, The Hague.

Kahler, F. and Kahler, G. 1979. Fusuliniden (Foraminifera) aus dem Karbon und Perm von Westanatolien und dem Iran. Mitteilungen österreichische geologische Gesellschaft, 70:187-269.

Kakuwa, Y. and Matsumoto, R. 2006. Cerium negative anomaly just before the Permian and Triassic boundary event- the upward expansion of anoxia in the water column. Palaeogeography, Palaeoclimatology, Palaeoecology, 229:335-344. 
Kobayashi, F. 1986. Middle Permian foraminifers of the Gozenyama Formation, southern Kwanto Mountains, Japan. Bulletin of the National Science Museum, series $C$ (Geology and Paleontology), 12:131-163.

Kobayashi, F. 1988. Middle Permian foraminifers of the Omi Limestone, central Japan. Bulletin of the National Science Museum, series C (Geology and Paleontology), 14:1-35.

Kobayashi, F. 1997. Upper Permian foraminifers from the Iwai-Kanyo area, West Tokyo, Japan. Journal of Foraminiferal Research, 27:186-195.

Kobayashi, F. 2004. Late Permian foraminifers from the limestone block in the southern Chichibu Terrane of west Shikoku, SW Japan. Journal of Paleontology, 78:62-70.

Kobayashi, F. 2006a. Middle Permian foraminifers of the Izuru and Nabeyama Formations in the Kuzu area, central Japan. Part 2. Schubertellid and ozawainellid fusulinoideans, and non-fusulinoidean foraminifers. Paleontological Research, 10:61-77.

Kobayashi, F. 2006b. Middle Permian foraminifers of Kaize, southern part of the Saku Basin, Nagano Prefecture, central Japan. Part 2. Paleontological Research, 10:179-194.

Kobayashi, F. 2011a. Middle Permian (Wordian) foraminifers of the Furen Limestone, Oita Prefecture, Japan. Humans and Nature, 22:21-25.

Kobayashi, F. 2011b. Permian fusuline faunas and biostratigraphy of the Akasaka limestone (Japan). Revue de Paléobiologie, Genève, 30:431-574.

Kobayashi, F. 2012. Permian non-fusuline foraminifers of the Akasaka Limestone (Japan). Revue de Paléobiologie, Genève, 31:313-335.

Kobayashi, F. 2013. Late Permian (Lopingian) foraminifers from the Tsukumi Limestone, southern Chichibu terrane of eastern Kyushu, Japan. Journal of Foraminiferal Research, 43:154-169.

Kobayashi, F. and Altiner, D. 2011. Discovery of the lower Murgabian (Middle Permian) based on neoschwagerinids and verbeekinids in the Taurides, southern Turkey. Rivista Italiana di Paleontologia e Stratigrafia, 117:39-50.

Kobayashi, F. and Ishii, K. 2003a. Permian fusulinaceans of the Surmaq Formation in the Abadeh region, central Iran. Rivista Italiana di Paleontologia e Stratigrafia, 109:307-337.

Kochansky-Devidé, V. 1965. Die Fusuliniden Foraminiferen aus dem Karbon und Perm in Velebit und in der Lika (Kroatien) Mittleres und Oberes Perm. Jugoslavenka Akademija Znanosti i Umjetnosti, Odjel za primodne nauke, Acta Geologica, V:101-150.

Kochansky-Devidé, V. 1970. Permski mikrofosili zahodnih Karavank. Geologija, Razprave in Porocila, 13:175-256.
Kolodka, C., Vennin, E., Vachard, D., Trocmé, V., and Goodarzi, M. 2012. Timing and progression of the end-Guadalupian crisis in the Fars province (Dalan Formation, Kuh-e Gakhum, Iran) constrained by foraminifers and other carbonate microfossils. Facies, 58:131-153.

Korte, C. and Kozur, H.W. 2005. Carbon isotope stratigraphy across the Permian/Triassic boundary at Jolfa (NW-Iran), Peitlerkofel (Sass de Pütia, Sass de Putia), Pufels (Bula, Bulla), Tesero (all three Southern Alps, Italy) and Gerennavár (Bükk Mts., Hungary). Journal Alpine Geology, 47:119-135.

Korte, C., Kozur, H.W. and Partoazar, H. 2004. Negative carbon isotope excursion at the Permian/Triassic boundary section at Zal, NW-Iran. Hallesches Jahrbuch Geowissenschaften, Reihe B, Beiheft, 18:6971.

Kotlyar, G.V., Zakharov, Y.D., Kochirkevich, B.V., Kropacheva, G.S., Rostovtscev, K.O., Chediya, I.O., Vuks, G.P., and Guseva, E.A. 1984. Pozdnepermskii etap evolyutsii organicheskogo mira, Dzhulfinskii $i$ Dorashamskii yarusy SSSR [Evolution of the latest Permian biota, Dzhulfian and Dorashamian stages of the USSR]. Akademiya Nauk SSSR, Dalnevostochnyi Nauchnyi Tsentr, Biologo-Pochvennyi Institut Leningrad:1-200. (In Russian)

Kotlyar, G.V., Zakharov, Yu.D., Kropacheva, G.S., Pronina, G.P., Chediya, I.O., and Burago, V.I. 1989. Pozdnepermskii etap evolyutsii organicheskogo mira, Midinskii yarus SSSR [Evolution of the latest Permian biota, Midian regional stage of the USSR]. Leningrad "Nauka", Leningradskoe Otdelennie:1-177. (In Russian)

Köylüoglu, M. and Altiner, D. 1989. Micropaléontologie (foraminifères) et biostratigraphie du Permien supérieur de la région d'Hakkari (SE Turquie). Revue de Paléobiologie, 8:467-503.

Kozur, H.W. 2004. Pelagic uppermost Permian and the Permian-Triassic boundary conodonts of Iran, Part I: Taxonomy. Hallesches Jahrbuch Geowissenschaften, Reihe B, Beiheft, 18:39-68.

Kozur, H.W. 2005. Pelagic uppermost Permian and the Permian-Triassic boundary conodonts of Iran. Part II: Investigated sections and evaluation of the conodont faunas. Hallesches Jahrbuch Geowissenschaften, Reihe B, Beiheft, 19:49-86.

Kozur, H.W. 2007. Biostratigraphy and event stratigraphy in Iran around the Permian-Triassic Boundary (PTB): Implications for the causes of the PTB biotic crisis. Global and Planetary Change, 55:155-176.

Lange, E. 1925. Eine mittelpermische Fauna von Guguk Bulat (Padanger Oberland, Sumatra). Verhandelingen van het geologisch mijnbouwkunding Genootschap voor Nederland en Koloniën, geologisch serie, 7:213-295.

Lankester, E.R. 1885. Protozoa, p. 830-836. In: Encyclopedia Britannica, 19, 9th edition. 
Lasemi, Y. 2001. Facies analysis, depositional environments and sequence stratigraphy of the upper PreCambrian and Paleozoic rocks of Iran. Geological Survey of Iran.

Leda, L., Korn, D., Ghaderi, A., Hairapetian, V., Struck, U., and Reimold, W.U. 2013. Lithostratigraphy and carbonate microfacies across the Permian-Triassic boundary near Julfa (NW Iran) and in the Baghuk Mountains (Central Iran). Facies, DOI 10.1007/ s10347-013-0366-0

Lee, J.S. 1931. Distribution of the dominant types of fusulinoid foraminifera in the Chinese Seas. Geological Society China, Bulletin, Grabau Anniversary, 10:273-290.

Lee, J.S. 1933. Taxonomic criteria of Fusulinidae with notes on seven new Permian genera. Memoirs of the National Research Institute of Geology, 14:1-32.

Leven, E.Ya. 1967. Stratigrafiya i fuzulinidy permskikh otlozheniy Pamira [Stratigraphy and fusulinids from the Permian deposits of the Pamir]. Akademiya Nauk SSSR, Geologicheskiy Institut, Izdatelstvo Nauka, 167:1-224. (In Russian)

Leven, E.Ya. 1970. O proiskhozhdenii vysshikh fuzulinid [On the origin of the advanced fusulinids]. Paleontologicheskiy Zhurnal, 1970 (3):18-25. (In Russian; English translation: Paleontological Journal, 1970, 3:303-309)

Leven, E.Ya. 1975. A stage scale for the Permian deposits of Tethys. International Geology Review, 18:807819. (English translation from Russian)

Leven, E.Ya. 1981. Permian-Tethys stage scale and correlation of sections of the Mediterranean-Alpine folded belt. IGCP, $N^{\circ} 5$ Newsletter, 3:100-112.

Leven, E.Ya. 1992. Problems of Tethyan Permian stratigraphy. International Geology Review, 34:976-985.

Leven, E.Ya. 1997. Permian stratigraphy and fusulinida of Afghanistan with their paleogeographic and paleotectonic implications. Geological Society of America, Special Paper, 316:1-134.

Leven, E.Ya. 1998. Permian fusulinid assemblages and stratigraphy of Transcaucasia. Rivista Italiana di Paleontologia e Stratigrafia, 104:299-328.

Leven, E.Ya. 2010. Origin of higher fusulinids of the order Neoschwagerinida Minato et Honjo, 1966. Stratigraphy and Geological Correlation, 18:290-297. (English translation)

Leven, E.Ya. and Gorgij, M.N. 2011. Fusulinids and Stratigraphy of the Carboniferous and Permian in Iran. Stratigraphy and Geological Correlation, 19:687-776. (English translation)

Likharev, B.K. 1939. Atlas rukovodyashchikh form iskopaemykh faun SSSR [Atlas of the leading forms of the fossil fauna of the U.S.S.R]. Tsentralnyi Nauchno-issledovatelskii Geologo-razvedochnyi Institut, Leningrad, 6 (permskaya sistema):1-268. (In Russian)
Lin, J.X. 1978. Carboniferous and Permian Foraminiferida, p. 10-43. In Hubei Institute of Geological Science and others (eds.), Paleontological Atlas of Central South China (micropaleontological volume). Geological Publishing House, Beijing. (In Chinese)

Lin, J.X. 1984. Biostratigraphy of the Yangtze Gorge area, (3) Late Paleozoic era. Museum Changzhou, Changzhou City, Jiangsu Province, Geological Publishing House:110-117 (In Chinese), 323-364. (In English)

Lin, J.X. 1985. Foraminifera from the Lower Permian Qixia Formation of Jiahe, Guangdong. Geological Review, 31 (4):289-294. (In Chinese)

Lin, J.X., Li, L.X., and Sun, Q.Y. 1990. Late Paleozoic foraminifers in South China. Science Publication House Beijing:1-269. (In Chinese)

Lipina, O.A. 1949. Melkie foraminifery pogrebennykh massivov Bashkirii [Smaller foraminifers from the buried massifs of Bashkiria]. Akademiya Nauk SSSR, Trudy Instituta Geologicheskikh Nauk, 105, geologiskaya seriya, 35:198-235. (In Russian; French translation BRGM, no. 791)

Loeblich, A.R. and Tappan, H. 1961. Suprageneric classification of the Rhizopodea. Journal of Paleontology, 35:245-330.

Loeblich, A.R. and Tappan, H. 1964. Sarcodina, chiefly "Thecamoebians" and Foraminiferida, p. C1-C900. In Moore, R.C. (ed.), Treatise of Invertebrate Paleontology, Part C, Protista 2. The Geological Society of America and the University of Kansas Press, 2 volumes.

Loeblich, A.R. and Tappan, H. 1982. Classification of the Foraminiferida. p. 22-36. In Broadhead, T.W. (ed.), Foraminifera, notes for a short course organized by Buzas M.A. and Sen Gupta, B.K. University of Tennessee, Knoxville, Department of Geological Sciences, Studies in Geology, 6.

Loeblich, A.R. and Tappan, H. 1984. Suprageneric classification of the Foraminiferida (Protozoa). Micropaleontology, 30:1-70.

Loeblich, A.R. and Tappan, H. 1987. Foraminiferal genera and their classification. Van Nostrand Reinhold Company Publisher, New York, 2 volumes.

Lys, M. and Marcoux, J. 1978. Les niveaux du Permien supérieur des Nappes d'Antalaya (Taurides occidentales, Turquie). Comptes Rendus Académie Sciences Paris, 286, série D:1417-1420.

Lys, M., Colchen, M., Bassoullet, J.P., Marcoux, J., and Mascle, G. 1980. La biozone à Colaniella parva du Permien supérieur et sa microfaune dans le bloc calcaire exotique de Lamayuru, Himalaya du Ladakh. Revue de Micropaléontologie, 23:76-108.

Malakhova, N.P. 1965. Foraminifera from the Permian deposits of the eastern slope of the Urals. Akademiya Nauk SSSR, Uralskii Filial, Trudy Instituta Geologii, 74:155-173. (In Russian) 
Mamet, B. 1970. Carbonate microfacies of the Windsor Group (Carboniferous), Nova Scotia and New Brunswick. Geological Survey of Canada, Paper 70-21:1121.

Mamet, B.L. 1974.Taxonomic note on Carboniferous Endothyracea. Journal of Foraminiferal Research, 4:200-204.

Mamet, B. 1996. Algues calcaires marines du Paléozoïque supérieur (Equateur, Bolivie). Annales de la Société géologique de Belgique, 117 (1994):155167.

Mamet, B. and Pinard, S. 1992. Note sur la taxonomie des petits foraminifères du Paléozoïque supérieur. Bulletin de la Société belge de Géologie, 99 (1990):373-398.

Marshall, F.C. 1969. Lower and Middle Pennsylvanian fusulinids from the Bird Spring Formation near Mountain Springs Pass, Clark County, Nevada. Brigham Young University Geological Studies, 16 (1):97-154.

Mertmann, D. 2000. Foraminiferal assemblages in Permian carbonates of the Zaluch Group (Salt Range and Trans Indus Range, Pakistan). Neues Jahrbuch für Paläontologie Monathefte, 2000 (3):129-146.

Mikhailov, A. 1939. K kharakteristike rodov nizhnekamennougolnykh foraminifer territorii SSSR; nizhekamennougolnye otlozhenii severo-zapadnogo kryla Podmoskogo basseina [On characteristic genera of Early Carboniferous foraminifers on the territory of the USSR; the Lower Carboniferous deposits of the northwestern limb of Moscow basin]. Sbornik Leningrad Geologicheskogo Upraleniya, Symposium, 3: 47-62. (In Russian)

Mikhalevich, V.I. 1980. Sistematika i evolyutsiya foraminifer $v$ svete novykhh dannykh po ikh litologii $i$ ultastrukture [Systematics and evolution of foraminifera by means of new data about their lithology and ultrastructure]. Trudy Zoologicheskogo Instituta, Akademiya Nauk SSSR, 94:42-61. (In Russian)

Mikhalevich, V.I. 1988. Sistema podklassa Miliolata (Foraminifera) [Systematics of the subclass Miliolata (Foraminifera)]. Trudy Zoologicheskogo Instituta, Akademiya Nauk SSSR, 184:77-110. (In Russian)

Mikhalevich, V.I. 1993. New higher taxa of the subclass Nodosariata (Foraminifera). Zoosystematica Rossica, 2:5-8.

Mikhalevich, V.I. 1998. Makrosistema Foraminifer [Macrosystematics of Foraminifera]. Izvestiya Akademii Nauk SSSR, seriya biologicheskaya 1998 (2):266271. (In Russian)

Mikhalevich, V.I. 2004. On the heterogeneity of the former Textulariina (Foraminifera), p. 317-349. In Bubík, M. and Kaminski, M.A. (eds.), Proceedings of the Sixth International Workshop on Agglutinated Foraminifera. Grzybowski Foundation Special Publication, 8.
Miklukho-Maklay, A.D. 1949. Verkhnepaleozoyskie fuzulinidy Sredney Azii, Fergana, Darvaz i Pamir [Late Paleozoic fusulinids of central Asia, Fergana, Darvaz and Pamir]. Leningradskii Gosudarstvennyi Ordena Lenina, Universitet Imeni A. A. Zhdanova, Institut Zemoi Kory, 3:1-111. (In Russian)

Miklukho-Maklay, A.D. 1953. K sistematike semeitsva Archaediscidae [On the systematics of the family Archaediscidae]. Ezhegodnik Vsesoyuznogo Paleontologischeskogo Obshchestva (1948-1953), 14:127131. (In Russian)

Miklukho-Maklay, A.D. 1958. Novoe semeistvo foraminifer - Tuberitinidae M.Maclay fam. nov. [A new family of Foraminifera, Tuberitinidae M.Maclay fam. nov.]. Voprosy Mikropaleontologii, 2:130-135. (In Russian)

Miklukho-Maklay, A.D. 1960. Novye rannekammennougolnye Arkhedistsidy [New early Carboniferous Archaediscids], p. 149-151. In Novye vidy drevnikh rasteniy i bespozvonochnykh SSSR. Trudy VSEGEI, Gosgotekhizdat, 1. (In Russian)

Miklukho-Maklay, A.D., Rauzer-Chernousova, D.M., and Rozovskaya, S.E. 1958. Sistematika i filogeniya fuzulinidei [Systematics and phylogeny of fusulinids]. Voprosy Mikropaleontologii, 2: 5-21. (In Russian; French translation: Editions Technip Paris)

Miklukho-Maklay, K.V. 1954. Foraminifery verkhnepermskikh otlozhenii severnogo Kavkaza [Foraminifers from the Late Permian deposits of the northern Caucasus]. Trudy VSEGEI, Gosgeoltekhizdat, 1:1163. (In Russian; French translation BRGM $\mathrm{n}^{\circ}$ 2683:1-216)

Miklukho-Maklay, K.V. 1960. Novye Kazanskie Lagenidy Russkoy Platformy [New Kazanian Lagenidae of the Russian Platform]. In: Novye vidy drevnikh rasteniy i bespozvonochnykh SSSR, pt. 1. Trudy VSEGEI, Gosgeoltekhizdat: 153-161. (In Russian)

Minato, M. and Honjo, S. 1966. Filogeniya podsemeystva Neoschwagerininae [Phylogeny of the subfamily Neoschwagerininae]. Voprosy Mikropaleontologii, 10:109-124. (In Russian)

Mohtat-Aghai, P. and Vachard, D. 2003. Dagmarita shahrezahensis n. sp. globivalvulinid foraminifer (Wuchiapingian, Late Permian, Central Iran). Rivista Italiana di Paleontologia i Stratigrafia, 109:37-44.

Mohtat-Aghai, P. and Vachard, D. 2005. Late Permian foraminiferal assemblages from the Hambast region (Central Iran) and their extinctions. Revista Española de Micropaleontología, 37:205-227.

Mohtat-Aghai, P., Vachard, D., and Krainer, K. 2009. Transported foraminifera in Palaeozoic deep red nodular limestones exemplified by latest Permian Neoendothyra in the Zal section (Julfa area, NW Iran). Revista Española de Micropaleontología, 41:197-213.

Mokhtar Pour, A. 1997. Lithology, Sedimentary Environment and Sequence of Permian Rocks in Alborz Area, Northern Iran. Unpublished PhD thesis, Islamic Azad University. (In Persian) 
Montenat, C., Lapparent, A. de, Lys, M., Termier, H., Termier, G., and Vachard, D. 1976. La transgression permienne et son substratum dans le Jebel Akhdar (Montagnes d'Oman, Péninsule Arabique). Annales de la Société géologique du Nord, 96:239-258.

Morozova, V.G. 1949. Predstaviteli semeytsv Lituolidae $i$ Textulariidae iz verkhnekamennougolnykh $i$ artinski otlozhenii bashkirskogo Priuralya [Members of families Lituolidae and Textulariidae from late Carboniferous and Artinskian from the Bashkir Pre-Urals]. Akademyia Nauk SSSR, Trudy Instituta Geologicheskikh Nauk, 105, geologicheskaya seriya, 35:244275. (In Russian; French translation: BRGM, $n^{\circ} 783$ ).

Nabavi, M. 1976. Introductory to the Geology of Iran. Geological Survey of Iran.

Nestell, G.P. and Nestell, M.K. 2006. Middle Permian (late Guadalupian) foraminifers from Dark Canyon, Guadalupe Mountains, New Mexico. Micropaleontology, 52:1-50.

Nestell, G.P., Sudar, M.N., Jovanovic, D., and KolarJurkovsek, T. 2009. Latest Permian foraminifers from the Vlasic mountain area, northwestern Serbia. Micropaleontology, 55:495-513.

Nestell, K.M. and Pronina, G.P. 1997. The distribution and age of the genus Hemigordiopsis. In Ross, C.A., Ross J.R.P., and Brenckle P.L. (eds.), Late Paleozoic foraminifera; their biostratigraphy, evolution, and paleoecology; and the Mid-Carboniferous boundary. Cushman Foundation for Foraminiferal Research, Special Publication, 36:105-110.

Neumayr, M. 1887. Die natürlichen Verwandtschaftverhältnisse der schalentragenden Foraminiferen. Sitzungsberichte der kaiserliche Akademie der Wissenschaften in Wien, Mathematisch-Naturwissenschaftliche Klasse, 95:156-186.

Nguyen Duc Tien 1979. Etude micropaléontologique (foraminifères) de matériaux du Permien du Cambodge. Unpublished $\mathrm{PhD}$ thesis, Université Paris Sud, Orsay.

Nguyen Duc Tien 1986a. Foraminifera and algae from the Permian of Kampuchea, p. 116-137. In Fontaine $\mathrm{H}$. et al. (eds.), The Permian of Southeast Asia, Appendix 2. CCOP Technical Bulletin, 18.

Nguyen Duc Tien 1986b. Foraminifera and algae from the Permian of Guguk Bulat and Silungkang, Sumatra, p. 138-147. In Fontaine $\mathrm{H}$. et al. (eds.), The Permian of Southeast Asia. CCOP Technical Bulletin, 18.

Nguyen Duc Tien 1988. Note on two "incertae sedis" from the Permian of West Thailand, p. 109-111. In Fontaine et al. (eds.), Late Palaeozoic and Mesozoic fossils of West Thailand and their environments. Appendix 1. CCOP Technical Bulletin, 20.

Okimura, Y. 1988. Primitive colaniellid foraminiferal assemblage from the Upper Permian Wargal Formation of Salt Range, Pakistan. Journal of Paleontology, 62:715-723.
Okimura, Y. and Ishii, K. i. 1981. Smaller foraminifera from the Abadeh Formation, Abadehian stratotype, central Iran. Reports Geological Survey Iran, 49:727.

Okimura, Y., Ishii, K.I., and Ross, C.A. 1985. Biostratigraphical significance and faunal provinces of Tethyan Late Permian smaller foraminifera, p. 115138. In Nakazawa, K. and Dickins, J.M. (eds.), The Tethys, her paleogeography and paleobiogeography from Paleozoic to Mesozoic. Tokai University Press.

Okuyucu, C., Vachard, D., and Göncüoglu, M.C. 2013. Refinements in biostratigraphy of theforaminiferal zone MFZ11 (late early Viséan, Mississippian) in the Cebeciköy Limestone (Istanbul Terrane, NW Turkey) and palaeogeographic implications. Bulletin of Geosciences, 88:621-645.

Ozawa, Y. 1925. On the classification of Fusulinidae. Journal of the College of Science, Imperial University of Tokyo, 45 (art. 6):1-90.

Ozawa, Y. 1927. Stratigraphical studies of the Fusulina limestones of Akasaka, Province of Mino. Imperial University of Tokyo, Journal, 2:121-164.

Pantic, S. 1965. Pilammina densa n. gen. n. sp. and other Ammodiscidae from the Middle Triassic in the Cr. Mnica (Montenegro). Geoloski Vjesnik, 18:189192.

Partoazar, H. 1995. Permian deposits in Iran p. 1-7 +1340. In Hushmandzadeh, A. (ed.), Treatise on the Geology of Iran, 22. (In Persian with English abstract)

Parvizi, T., Rashidi K., and Vachard, D. 2013. Middle Permian calcareous algae and microproblematica (Dalan Formation, Dena Mountain, High Zagros, SW Iran). Facies: doi:10.1007/s10347-012-0357-6.

Phillips, J. 1846. On the remains of microscopic animals in the rocks of Yorkshire. Proceedings of the Geological and Polytechnic Society of the West Riding of Yorkshire (1844-1845), 2:274-285.

Pinard, S. and Mamet, B. 1998. Taxonomie des petits foraminifères du Carbonifère supérieur-Permien inférieur du bassin de Sverdrup, Arctique canadien. Paleontographica Canadiana, 15:1-253.

Plummer, H.J. 1930. Calcareous foraminifera in the Brownwood shale near Bridgeport, Texas. Bulletin University of Texas, 3019:5-21.

Praturlon, A. 1963. Dasycladaceae from Upper Permian of the Dolomites (Italy). Geologica Romana, 2:119150.

Pronina, G.P. 1988a. The Late Permian smaller foraminifers of Transcaucasus. Revue de Paléobiologie, volume spécial no. 2, Benthos'86, 1:89-96.

Pronina, G.P. 1988b. Poznepermskie Miliolyaty Zakavkazya [Late Permian Miliolates of Transcaucasia]. Trudy Zoologicheskogo Instituta, Akademiya Nauk SSSR, 184:49-63. (In Russian)

Pronina, G.P. 1995. Upper Permian small foraminifers zonal standard in the Tethyan realm. 13e International Congress on Carboniferous-Permian (XIII ICC$P)$, Kracow, Abstracts:118. 
Pronina, G.P. 1999. Novye vidy melkikh foraminifer iz verkhnei Permi Zakavkazya [New species of smaller foraminifera from Late Permian of Transcaucasia]. Sankt-Peterburgskii Gosudarstvennyi Universitet, Voprosy Paleontologii, 11:4-14. (In Russian)

Pronina, G.P. and Gubenko, T.A. 1990. Planoarkhedistsidy pozdnei Permi Zakavkazya (Late Permian planoarchaediscids from Transcaucasia). Paleontologicheskii Zhurnal, 1990 2:119-123. (In Russian; English translation: Paleontological Journal, 1990 2:119-123)

Pronina-Nestell, G.P. and Nestell, M.K. 2001. Late Changhsingian foraminifers of the northwestern Caucasus. Micropaleontology, 47:205-234.

Rauzer-Chernousova, D.M. 1948. Nekotorye novye nizhnekamennougolnye foraminifery Syzranskogo raiona [Some new foraminifers from the Early Carboniferous of Syzran area]. Akademiya Nauk SSSR, Trudy Instituta Geologicheskikh Nauk, 62, geologicheskaya seriya, 19:239-243. (In Russian)

Rauzer-Chernousova, D.M., Bensh, F.R., Vdovenko, M.V., Gibshman, N.B., Leven, E.Ya., Lipina, O.A., Reitlinger, E.A., Solovieva, M.N., and Chediya, I.O. 1996. Spravochnik po sistematike foraminifer Paleozoya; Endothyroidy, Fuzulinoidy [Reference-book on the systematics of Paleozoic foraminifers; Endothyroida and Fusulinoida]. Rossiiskaya Akademiya Nauk, Geologicheskii Institut, Moskva "Nauka":1207. (In Russian)

Rauzer-Chernousova, D.M. and Fursenko, A.V. 1937. Opredelitel foraminifer neftenosnykh raionov SSSR [Determination of foraminifera from the petroliferous regions of the USSR]. Glavnaya Redaktsya GornoToplivnoi Literatury Leningrad:1-315. (In Russian)

Rauzer-Chernousova, D.M. and Fursenko, A.V. 1959. Osnovy Paleontologii [Fundamentals of paleontology], spravochnik dlya paleontologov i geologov SSSR, Tom 1, Obshchaya chast proteishie [Class Protista] Izdateltsvo Akademii:1-368. (In Russian)

Rauzer-Chernousova, D.M., Gryslova, N.D., Kireeva, G.D., Leontovich, G.E., Safonova, T.P., and Chernova, E.I. 1951. Srednekamennougolnye fuzulinidy Russkoi Platformyi sopredelnykh oblastei [Middle Carboniferous fusulinids of the Russian Platform and adjacent regions]. Akademiya Nauk SSR, Institut Geologichevskikh Nauk, Ministerstvo Neftyanoi Promyshlennosti, SSSR:1-380. (In Russian)

Reichel, M. 1946. Sur quelques foraminifères nouveaux du Permien méditerranéen. Eclogae Geologicae Helvetiae, 38 (1945):524-560.

Reiss, Z. 1963. Reclassification of perforate Foraminifera. Bulletin of the Geological Survey of Israel, 35:1111.

Reitlinger, E.A. 1949. Melkie foraminifery nizhnei chasti srednego karbona Srednego Urala i Prikamya [Smaller foraminifers in the lower part of the Middle Carboniferous in the Central Ural and Prekama]. Akademiya Nauk SSSR, Izvestia, geologicheskaya seriya se, 6:149-164. (In Russian)
Reitlinger, E.A. 1950. Foraminifery srednekamennougolnykh otlozhenii tsentralnoi chasti Russkoi platformy (isklyuchaya semeistvo Fusulinidae) [Foraminifera from Middle Carboniferous deposits of the central part of the Russian Platform (excepting the family Fusulinidae)]. Akademiya Nauk SSSR., Trudy Instituta Geologicheskikh Nauk, 126, geologichevskaya seriya, 47:1-126. (In Russian, French translation BRGM no. 1456)

Reitlinger, E.A. 1965. Razvitie foraminifer $v$ pozdnepermskogo i rannetriasovyuf epokhi na territorii Zakavkazya [Development of the foraminifers in the Late Permian and Early Triassic times in Transcaucasia]. Voprosy Mikropaleontologii, 9:45-70. (In Russian)

Rhumbler, L. 1895. Entwurf eines natürlichen Systems der Thalamophoren. Nachrichten von der Gesellschaft der Wissenschaften zu Göttingen, Math. Phys. Klasse, Jahr 1895 (1):51-98.

Richoz, S. 2006. Stratigraphie et variations isotopiques du carbone dans le Permien supérieur et le Trias inférieur de la Néotéthys (Turquie, Oman et Iran). Mémoires de Géologie de Lausanne, 46:1-251.

Richoz, S., Krystyn, L., Baud, A., Brandner, R., Horacek, M., and Mohtat-Aghai, P. 2010. Permian-Triassic boundary interval in the Middle East (Iran and $\mathrm{N}$. Oman): progressive environmental change from detailed carbonate carbon isotope marine curve and sedimentary evolution. Journal of Asian Earth Sciences, 39:236-253.

Rigaud, S., Vachard, D., Martini, R., and Rettori, R. Agglutinated versus microgranular: End of a paradigm? Journal of Systematic Palaeontology (in press).

Rozovskaya, S.E. 1965. Fusulinidy, p. 26-34, 137-146. In Ruzhentsev V.E. and Sarycheva, T.G. (eds.), Razvitie i smena morskikh organizmov na rubezhe Paleozoya i Mezozoya. Akademiya Nauk SSSR, Trudy Paleontologicheskogo Instituta, 108. (In Russian)

Rui, L. 1979. Upper Permian fusulinids from western Guizhou. Acta Paleontologica Sinica, 18:271-297. (In Chinese with English abstract)

Rzehak, A. 1885. Bemerkungen über einige Foraminiferen der Oligocän Formation. Verhandlunge des Naturforschenden Vereins in Brünn, 23:123-129.

Salaj, J., Borza, K., and Samuel, O. 1983. Triassic Foraminifera of the West Carpathians. Geologicky Ustav Dionyza Stura:1-213.

Schlagintweit, F. 2011. Remarks on the Pseudovermiporella Elliott, 1958 and the origin of thaumatoporellacean algae, p. 76-77. In Bucur, I.I. and Sasaran, E. (eds.), Abstracts. 10th International Symposium on Fossil Algae, Cluj-Napoca, Romania, 12-18 September 2011.

Schubert, R.J. 1908. Beiträge zu einer natürlichen Systematik der Foraminiferen. Neues Jahrbuch für Mineralogie, Geologie und Paläontologie, BeilageBand, 25:232-260. 
Schubert, R.J. 1921. Paläontologische Daten zur Stammesgeschichte der Protozoen. Paläontologische Zeitschrift, 3 (1920):129-188.

Schultze, M.S. 1854. Über den Organismus der Polythalamien (Foraminiferen) nebst Bemerkungen über die Rhizopoden im allgemeinen. Wielhem Engelmann, Leipzig.

Schwager, C. 1883. Karbonische Foraminiferen aus China und Japan. In von Richthofen, F., China. Berlin, Dietrich Reimer, Band 4:106-159.

Sellier de Civrieux, J.M. and Dessauvagie, T.F.J. 1965. Reclassification de quelques Nodosariidae, particulièrement du Permien au Lias. Maden Tetkik ve Arama Enstitüsü Yayinlarindan (M.T.A.), 124:1-178.

Sengör, A.M.C., Altiner, D., Clin, A., Ustaösmer, T., and Hsü, K.J. 1988. Origin and assembly of the Tethyside orogenic collage at the expense of Gondwana Land. In Audley-Charles, M.G. and Hallam, A. (eds.), Gondwana and Tethys. Special Publication Geological Society of London, Special Publication, 37:119-181.

Shabanian, R., Tehrani, K.K., and Momeni, I. 2007. Stratigraphy and micropaleontology of the Permian rocks in NW Iran. Geosciences:1-12.

Shang, Q.H., Vachard, D., and Caridroit, M. 2003. Smaller foraminifera from the late Changhsingian (latest Permian) of southern Guangxi and discussion on the Permian-Triassic boundary. Acta Micropaleontologica Sinica, 20:377-388.

Sharland, P.R., Archer, R., Casey, D.M., Davies, R.B., Hall, S.H., Heward, A.P., Horbury, A.D., and Simmons, M.D. 2001. Arabian Plate Sequence Stratigraphy. GeoArabia, Special Publication, 2:1-371.

Shen, S.Z. and Mei, S.L. 2010. Lopingian (Late Permian) high-resolution conodont biostratigraphy in Iran with comparison to South China zonation. Geological Journal, 45:135-161.

Sheng, J.C. 1955. Some fusulinids from Changhsing Limestone. Acta Paleontologica Sinica, 3:287-308.

Sheng, J.C. 1963. Permian fusulinids of Kwangsi, Kueichow and Szechuan. Palaeontologica Sinica, new series, B, 10:1-247. (In Chinese and English)

Shlykova, T.I. 1969. Novyy rod rannekamennougolnykh foraminifer [New genera of Early Carboniferous foraminifers]. Voprosy Mikropaleontologii, 12:47-50. (In Russian)

Skinner, J.W. 1969. Permian foraminifera from Turkey. The University of Kansas, Paleontological Contribution, Paper 36:1-14.

Solovieva, M.N. 1978. K sisteme foraminifer (interpretatsiya biologicheskogo znacheniya osobennostey strukturnoy i prostranstvennoy organizatsii foraminifer [On the systematics of the foraminifers (interpretation of the biological significance of structural feartures and spatial organization of the foraminifers)]. Byulletin Moskovskoe Obshchestva Ispytateley Prirody, Otdelenie Geologicheskoe, 53:159-160. (In Russian)
Song, H.J., Tong, J.N., and Chen, Z.Q. 2011. Evolutionary dynamics of the Permian-Triassic foraminifer size: Evidence for Lilliput effect in the end-Permian mass extinction and its aftermath. Palaeogeography, Palaeoclimatology, Palaeoecology, 308:98-110.

Song, H.J., Tong, J.N., Chen, Z.Q., Yang, H., and Wang Y.B. 2009. End-Permian mass extinction of foraminifers in the Nanpanjiang Basin, South China. Journal of Paleontology, 83:718-738.

Song, H.J., Wignall, P.L., Tong, J.N., and Yin, H.F. 2013. Two pulses of extinction during the Permian-Triassic crisis. Nature Geoscience, 6:52-56.

Sosnina, M.I. 1981. Nekotorye permskie fuzulinidy Dalnego Vostoka [Some Permian fusulinid from the Far East]. Ezhegodnik Vsesoyuznogo, Paleontologicheskogo Obshchestva, 24:31-41. (In Russian)

Sosnina, M.I. and Nikitina, A.P. 1977. Melkie foraminifery verkhnei permi Yuzhnogo Primoriya [Smaller foraminifers of the Late Permian of southern Primorye]. In: Iskopaemaya flora $i$ fauna Dalnego Vostoka $i$ voprosy stratigrafii Fanerozoya [Fossil flora and fauna of Far East and problems of Phanerozoic stratigraphy]. Akademiya Nauk SSSR, Dalnevostochnyi Nauchniyi Tsentr, Dalnevostochnyi Geologicheskii. Institut:27-52. (In Russian)

Stampfli, G.M. 1978. Etude géologique générale de l'Elbourz oriental au Sud de Gonbad-e Qabus, Iran NE. Unpublished PhD, Université de Genève, No. 1868.

Stepanov, D.L., Golshani, F., and Stöcklin, J. 1969. Upper Permian and Permian-Triassic Boundary in North Iran. Geological Survey Iran Report, 12:1-72.

Suleimanov, I.S. 1949. Novye vidy fuzulinid podsemeystva Schubertellinae Skinner iz kamennougol'nykh i nizhnepermskikh otlozheniy Bashkirskogo Priural'ya [New species of fusulinids from the sub-family Schubertellinae Skinner from the Carboniferous and Lower Permian of the Preural Bashkir]. Akademiya Nauk SSSR, Trudy Instituta Geologicheskykh Nauk, 105, geologicheskaya seriya, 35:22-43. (In Russian)

Teichert, C., Kummel, B., and Sweet, W.C. 1973. Permian-Triassic strata, Kuh-e-Ali Bashi, northwestern Iran. Bulletin Museum Comparative. Zoology, Harvard University, 145:359-472.

Théry, J.M., Vachard, D., and Dransart, E. 2007. Late Permian limestones and Permian-Triassic Boundary: new biostratigraphic, palaeobiogeographic and geochemical data in Caucasus and Eastern Europe, p. 255-274. In Alvaro, J.J., Aretz, M., Boulvain, F., Munnecke, A., Vachard, D., and Vennin, E. (eds.), Palaeozoic Reeefs and Bioaccumulations: Climatic and Evolutionary Controls. Geological Society London, Special Publications, 275.

Thompson, M.L. 1937. Fusulinids of the subfamily Schubertellinae. Journal of Paleontology, 11: 118125. 
Ueno, K. 1992. Permian foraminifers from the Takakurayama Group of the southern Abukuma Mountains, Northeast Japan. Transactions and Proceedings Paleontological Society Japan, new series, 168:1265-1295.

Ueno, K. 2001. Jinzhangia, a new staffellid fusulinoidea from the Middle Permian Daaozi Formation of the Baoshan Block, West Yunnan, China. Journal of Foraminiferal Research, 31:233-243.

Ueno, K., Miyahigashi, A., and Chaoentitirat, T. 2010. The Lopingian (Late Permian) of mid-oceanic carbonates in the Eastern Palaeotethys: stratigraphical outline and foraminiferal faunal [sic] succession. Geological Journal, 45:285-307.

Ueno, K. and Tsutsumi S. 2009. Lopingian (Late Permian) foraminiferal faunal succession of a PaleoTethyan mid-oceanic carbonate buildup: Shifodong Formation in the Changning-Menglian Belt, Southwest China. Island Arc, 18:69-93.

Ünal, E., Altiner, D., Ömer Yilmaz, I., and Özkan-Altiner, S. 2003. Cyclic sedimentation across the PermianTriassic boundary (Central Taurides, Turkey). Rivista Italiana di Paleontologia i Stratigrafia, 109:359-376.

Vachard, D. 1980. Téthys et Gondwana au Paléozoïque supérieur; les données afghanes: biostratigraphie, micropaléontologie, paléogéographie. Documents et Travaux IGAL, Institut Géologique Albert de Lapparent, 2, 2 volumes:1-463.

Vachard, D. 1994. Foraminifères et moravamminides du Givétien et du Frasnien du domaine Ligérien (Massif Armoricain, France). Palaeontographica, A, 231:192.

Vachard, D. 1996. Iran, p. 489-521. In Wagner, R., Winkler Prins, C.F., and Granados, L.F. (eds.), The Carboniferous of the World 3. Instituto Tecnológico GeoMinero de España (IGME) \& Nationaal Natuurhistorisch Museum, Publishers.

Vachard, D. and Beckary, S. 1991. Algues et foraminifères bachkiriens des coal balls de la Mine Rosario (Truebano, Léon, Espagne). Revue de Paléobiologie, 10:315-357.

Vachard, D., Clift, P., and Decrouez, D. 1993a. Une association à Pseudodunbarula (fusulinoïde) du Permien supérieur (Djoulfien) remaniée dans le Jurassique d'Argolide (Péloponnèse, Grèce). Revue de Paléobiologie, 12:217-242.

Vachard, D. and Ferrière, J. 1991. Une association à Yabeina (foraminifère fusulinoïde) dans le Midien (Permien supérieur) de la région de Whangaroa (Baie d'Orua, Nouvelle-Zélande). Revue de Micropaléontologie, 34:201-230.

Vachard, D., Gaillot, J., Vaslet, D., and Le Nindre, Y.M. 2005. Foraminifers and algae from the Khuff Formation (late Middle Permian-Early Triassic) of central Saudi Arabia. GeoArabia, 10:137-186.
Vachard, D., Gaillot, J., Pille, L., and Blazejowski, B. 2006. Problems of Biseriamminoidea, Mississippian-Permian biserially coiled foraminifera. A reappraisal with proposals. Revista Española de Micropaleontología, 38 (2-3):453-492.

Vachard, D., Hauser, M., Martini, R., Zaninetti, L., Matter, A., and Peters, T. 2001. New algae and problematica of algal affinity from the Permian of the Aseelah Unit of the Batain Plain, (East Oman). Geobios, 34:375404.

Vachard, D., Hauser, M., Martini, R., Zaninetti, L., Matter, A., and Peters, T. 2002. Middle Permian (Midian) foraminiferal assemblages from the Batain Plain (Eastern Oman): their significance to Neotethyan paleogeography. Journal of Foraminiferal Research, 32:155-172.

Vachard, D. and Krainer, K. 2001. Smaller foraminifers, characteristic algae and pseudo-algae of the latest Carboniferous/early Permian Rattendorf Group, Carnic Alps (Austria/ltaly). Rivista Italiana de Paleontologia e Stratigrafia, 107:169-195.

Vachard, D., Krainer, K., and Lucas, S. 2013. Pennsylvanian (Late Carboniferous) calcareous microfossils from Cedro Peak (New Mexico, USA); Part 2: smaller foraminifers and fusulinids. Annales de Paléontologie, 99:1-42.

Vachard, D., Martini, R., Zaninetti, L., and ZambetakisLekkas, A. 1993b. Révision micropaléontologique (foraminifères, algues) du Permien inférieur (Sakmarien) et supérieur (Dorashamien) du Mont Beletsi (Attique, Grèce). Bollettino Societá Paleontologica Italiana, 32:89-112.

Vachard, D. and Montenat, C. 1981. Biostratigraphie, micropaléontologie et paléogéographie du Permien de la région de Tezak (Montagnes Centrales d'Afghanistan). Palaeontographica B, 178:1-88.

Vachard, D. and Montenat, C. 1996. The Carboniferous of Afghanistan, p. 459-487. In Wagner, R., Winkler Prins, C.F., and Granados, L.F. (eds.), The Carboniferous of the World 3. Instituto Tecnológico GeoMinero de España (IGME) \& Nationaal Natuurhistorisch Museum, Publishers.

Vachard, D., Oviedo, A., Flores de Dios, A., Malpica, R., Brunner, P., Guerrero, M., and Buitron, B.E. 1993c. Barranca d'Olinala (Guerrero) : une coupe de référence pour le Permien du Mexique Central; étude préliminaire. Annales de la Société Géologique du Nord, 2:153-160.

Vachard, D., Pille, L., and Gaillot, J. 2010.Palaeozoic Foraminifera: systematics, palaeoecology and responses to the global changes. Les foraminifères paléozoïques: systématique, paléoécologie et réponses aux changements globaux. Revue de Micropaléontologie, 53:209-254.

Vachard, D., Rettori, R., Angiolini, L., and Checconi, A. 2008. Glomomidiella gen. n. (Foraminifera, Miliolata, Neodiscidae): A new genus from the late Guadalupian-Lopingian of Hydra Island (Greece). Rivista Italiana di Paleontologia e Stratigrafia, 114:349-361. 
Vachard, D., Zambetakis-Lekkas, A., Skourtsos, E., Martini, R., and Zaninetti, L. 2003. Foraminifera, algae and carbonate microproblematica from the Late Wuchiapingian/ Dzhulfian (Late Permian) of Peloponnesus (Greece). Rivista Italiana di Paleontologia $i$ Stratigrafia, 109:339-358.

Vdovenko, M.V., Rauzer-Chernousova, D.M., Reitlinger, E.A., and Sabirov, A.A. 1993. Spravochnik po sistematike melkikh foraminifer paleozoya [Guide for the systematics of Palaeozoic smaller foraminifers]. Rossiiskaya Akademiya Nauk, Komissiya po Mikropaleontologii, "Nauka", Moscow:1-128. (In Russian)

von Möller, V. 1878. Die spiral-gewundenen Foraminiferen des russischen Kohlenkalks. Mémoires de l'Académie Impériale des Sciences de St Pétersbourg, 7th series, 25:1-147.

Wang, K. 1976. The Foraminifera from the Changhsing Formation in western Guizhou. Acta Paleontologica Sinica, 15:187-195. (In Chinese)

Wang, K.L. and Sun, X.F. 1973. [Carboniferous and Permian Foraminifera of the Chinling Range and its geologic significance]. Acta Geologica Sinica, 2:137178. (In Chinese with English abstract)

Wang, Y. and Ueno, K. 2003. Latest Permian fusulinoideans and smaller foraminifers in the Meili section, Guangxi, S. China. Permophiles, 42:19-21.

Wang, Y., Ueno, K., Zhang, Y.C., and Cao, C.Q. 2010. The Changhsingian foraminiferal fauna of a Neotethyan seamount: the Gyanyima Limestone along the Yarlung-Zangbo Suture in southern Tibet, China. Geological Journal, 45:308-318.

Wang, Y.J. 1974. [A handbook of the stratigraphy and paleontology in Southwest China]. Nanking Institute of Geology and Paleontology eds: Science Press, Academia Sinica:1-454. (In Chinese)

Wedekind, P.R. 1937. Einführung in die Grundlagen der historischen Geologie. Band II. Mikrobiostratigraphie die Korallen und Foraminiferenzeit. Stuttgart: Ferdinand Enke.

Wendt, J. 1969. Foraminiferen-"Riffe" im karnischen Hallstätter Kalk des Feuerkogels (Steiermark, Österreich). Paleontologisches Zeitschrift, 43:177-193.

Whittaker, D., Zaninetti, L., and Altiner, D. 1979. Further remarks on the micropaleontology of the late Permian of eastern Burma. Notes du Laboratoire de Paléontologie de l'Université de Genève, 5:11-18.

Wignall, P.B., Bond, D.P.G., Haas, J., Wang, W., Jiang, H.S., Lai X.L., Altiner, D., Védrine, S., Hips, K., Zajzon, N., Sun, Y.D., and Newton, R.J. 2012. Capitanian (Middle Permian) mass extinction and recovery in Western Tethys: A fossil, facies, and $\delta^{13} \mathrm{c}$ study from Hungary and Hydra Island (Greece). Palaios, 27:78-89 DOI: 10.2110/palo.2011.p11-058r
Wignall, P.B. and Twitchett, R.J. 2002. Extent, duration, and nature of the Permian-Triassic superanoxic event. In Koeberl, C. and MacLeod, K.C. (eds.), Catastrophic Events and Mass Extinctions: Impacts and Beyond. Geological Society of America, Special Paper, 356:395-413.

Wolanska, H. 1959. Agathammina pusilla (Geinitz) z dolnego cechsztynu Sudetów i Gór Swietokrzyskich. Acta Paleontologica Polonica, 4:27-59.

Yabe, H. 1993. On a Fusulina limestone with Helicoprion in Japan. Geological Society Tokyo Journal, 10:1-13.

Yanagida, J., Sakagami, S., Ishibashi, T., Kawabe, T., Hatta, A., Nakoornsri, N., Sugiyama, T., Chonglakamani, C., Ingavat-Helmcke, R., Chongkanchanasoontorn, Y., Piyasin, S., and Wongwanich, T. 1988. Biostratigraphic study of Paleozoic and Mesozoic groups in central and northern Thailand, an interim report. Geological Survey Division, Department of Mineral Resources, Bangkok:1-47.

Young, J. and Armstrong, J. 1871. On the Carboniferous fossils of the west of Scotland. Transactions of the Geological Society of Glasgow, 3 (supplement):1103.

Zaninetti, L., Altiner, D., and Çatal, E. 1981. Foraminifères et biostratigraphie dans le Permien supérieur du Taurus oriental, Turquie. Notes du Laboratoire de Paléontologie de l'Université de Genève, 7:1-38.

Zaninetti, L. and Jenny-Deshusses, C. 1985. Les Paraglobivalvulines (foraminifères) dans le Permien supérieur téthysien; répartition géographique et description de Paraglobivalvulinoides n. gen. Revue de Paléobiologie, 4:343-346.

Zhang, Hong 1989. A discussion on Diplosphaerina and Tuberitina (Foraminifera) from Late Paleozoic of North China Platform. Acta Micropaleontologica Sinica, 6:283-288. (In Chinese)

Zhang, Y. C., Cheng, L. R., and Shen, S. Z. 2010. Late Gudalupian (Middle Permian) fusuline fauna from the Xiala Formation in Xianza County, Central Tibet, implications of the rifting time of the Lhasa Block. Journal of Paleontology, 84:955-973.

Zhang, Y. C., Wang, Y., Zhang, Y. J., and Yuan, D. X. 2012. Kungurian (Late Cisuralian) fusuline fauna from the Cuozheqiangma area, northern Tibet and its palaeobiogeographical implications. Palaeoword, 21:139-152.

Zhao, Jin-Ke, Sheng, Jin-Zhang, Yao, Zhao-Qi, Liang, Xiluo, Chen, Chu-Zhen, Rui, Lin and Liao, Zhuo-Ting 1981. The Changhsingian and Permian-Triassic boundary of South-China. Bulletin Nanjing Institute Geology and Paleontology, Academia Sinica, 2:5869. (In Chinese with English abstract)39 